University of Louisville

ThinkIR: The University of Louisville's Institutional Repository

Electronic Theses and Dissertations

8-2010

\title{
SA-4-1BBL as a modulator of $T$ effector to $T$ regulatory cell conversion.
}

Shravan Madireddi 1980-

University of Louisville

Follow this and additional works at: https://ir.library.louisville.edu/etd

\section{Recommended Citation}

Madireddi, Shravan 1980-, "SA-4-1BBL as a modulator of T effector to T regulatory cell conversion." (2010). Electronic Theses and Dissertations. Paper 880.

https://doi.org/10.18297/etd/880

This Doctoral Dissertation is brought to you for free and open access by ThinkIR: The University of Louisville's Institutional Repository. It has been accepted for inclusion in Electronic Theses and Dissertations by an authorized administrator of ThinkIR: The University of Louisville's Institutional Repository. This title appears here courtesy of the author, who has retained all other copyrights. For more information, please contact thinkir@louisville.edu. 


\title{
SA-4-1BBL AS A MODULATOR OF T EFFECTOR TO T REGULATORY CELL CONVERSION
}

By

Shravan Madireddi

B.Sc. Osmania University, 2000

M.Sc. SRTM University, 2003

M.S. University of Louisville, 2007

\begin{abstract}
A Dissertation
Submitted to the Faculty of the

Graduate School of the University of Louisville

In Partial Fulfillment of the Requirements
\end{abstract}

For the Degree of

Doctor of Philosophy

Department of Microbiology and Immunology

University of Louisville

Louisville, Kentucky

August 2010 
Copyright 2010 by Shravan Madireddi

All rights reserved 


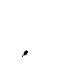




\title{
SA-4-1BBL AS A MODULATOR OF T EFFECTOR TO T REGULATORY CELL CONVERSION
}

\author{
By \\ Shravan Madireddi \\ B.Sc. Osmania University, 2000 \\ M.Sc. SRTM University, 2003 \\ M.S. University of Louisville, 2007 \\ A Dissertation Approved on
}

July 22,2010

by the following Dissertation Committee:

Dissertation Director 


\section{DEDICATION}

I would like to dedicate this dissertation to my wife Swathi and to my beloved family. 


\section{ACKNOWLEDGEMENT}

Though the following dissertation is an individual work, yet it is obviously not possible without the personal and practical support of numerous people. Firstly, I would like to thank my mentor Dr. Haval Shirwan for allowing me to work in his laboratory. His everlasting enthusiasm and unlimited zeal have been major driving forces throughout my graduate career at the University of Louisville. I have been truly fortunate to have an advisor who gave me the freedom to explore on my own and at the same time the guidance to recover when my steps faltered. He taught me how to write scientific documents and improve my presentation skills. His patience and support helped me overcome many crisis situations. A special thanks for Dr. Esma Yolcu for all her support, technically, professionally and personally. Her unwavering faith and confidence in my abilities and in me is what has shaped me to be the person I am today. Thank you for everything.

I would like to thank my committee members Dr. Michele M Kosiewicz, Dr. Pascale Alard and Dr. Jun Yan for their suggestions, thoughtful comments and guidance over the years. Thanks to the Department of Microbiology and Immunology and IPIBS program for giving me the opportunity to study at University of Louisville.

I would also like to thank members, past and present of Dr. Shirwan's lab for their help and support. I would like to take this opportunity to thank Rich-henry, Orlando and Hong for helping a great deal in my experiments. Many thanks to all the past and present 
members of the lab, especially Kutlu, Chantale, Rajesh, Abhishek, Laura and Sun for their friendship and support. I am really going to miss working with you!

All these year I have been an integral part of Institute of Cellular Therapeutics (ICT) family. Many thanks to the faculty, administrative staff and other research and nonresearch staff including barrier staff at ICT for providing state of the art facilities and great working environment. My special thanks to Barry Udis, Thomas Miller and late Michael K Tanner for those long cell sorting schedules.

My very special thanks to the one person whom I owe everything I am today, my father, Raghava Reddy. My thanks also go out to my mother Sabitha who showed me the true essence of my life. I would also like to thank my wife Swathi and my sisters, shravanthi and Sowmya for their love and support. 


\section{ABSTRACT \\ SA-4-1BBL AS A MODULATOR OF T EFFECTOR TO T REGULATORY CELL CONVERSION \\ Shravan Madireddi}

July 22,2010

The immune system is of profound importance for host survival due to its ability to clear many acquired diseases. In case of infections and cancer, disease arises due to under-performance of immune system. Whereas in autoimmunity and transplantation, deleterious immunity to normal self-antigens and allogeneic antigens arises due to enhanced immune responses. Regulatory $\mathrm{T}$ (Treg) cells play a critical role in immune homeostasis in health and disease.

Treg cells are important in the development and maintenance of immune tolerance towards self or transplantation antigens. However, Treg cells also play an obstructive role in cancer-related immunity by suppressing various effector cells. Therefore, development of immunomodulatory approaches that can either promote or inhibit expansion and/or suppressive function of Treg cells in the context of autoimmunity/transplantation and cancer/chronic infections, respectively, is of great importance. Treg cells require three signals, mediated by TCR-MHC-II/peptide (Signal 1), costimulation (signal 2) and cytokines (signal 3), for development, maintenance and function. Manipulation of any of these signals, therefore, may present an effective approach in modulating Treg cells in the context of various disease settings. The goal of 
this dissertation is to exploit signal 2 for modulating Treg cells in the setting of cancer and transplantation for immunotherapy.

We chose the 4-1BB signaling pathway because of its constitutive expression on Treg cells and its important role in both innate and adaptive immunity. Using a chimeric 4-1BBL (SA-4-1BBL), we herein show that signaling through 4-1BB inhibits antigen and TGF- $\beta$ driven conversion of Teff into Treg cells. This effect is primarily mediated by SA-4-1BBL-induced IFN- $\gamma$ production in Teff cells. Importantly, vaccination of mice with established ovalbumin (TAA) expressing EG.7 tumors with SA-4-1BBL results in the blockade of Teff cell conversion into Treg cells within the tumor and spleen. In contrast, SA-4-1BBL in the presence of IL-2 and rapamycin promotes the conversion of naïve $\mathrm{CD}^{+} \mathrm{T}$ cells into Treg cells. Provision of three signals (allogeneic TCR stimulation, 4-1BBL mediated co-stimulation, and IL-2 cytokine) in the presence of rapamycin was effective in enhancing the generation/expansion of Treg cells. This is unique to 4-1BB as signaling through CD28 did not increase the generation of Treg cells. Collectively, these novel functions of soluble form of SA-4-1BBL represent a promising approach to inhibit/promote Treg cell generation/expansion with potential therapeutic applications in cancer immunotherapy and transplantation. 


\section{TABLE OF CONTENTS}

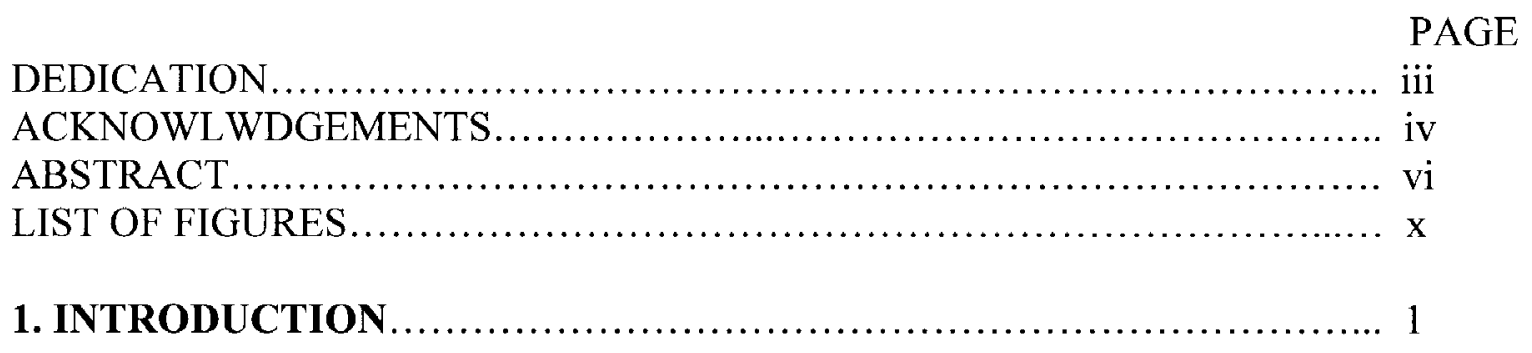

\section{IMMUNOMODULATORY FUNCTION OF SA-4-1BBL ON CONVERSION OF NAÏVE CD4 ${ }^{+} \mathrm{T}$ CELLS INTO CD4 ${ }^{+} \mathrm{FoxP3}^{+} \mathrm{T}$ CELLS}

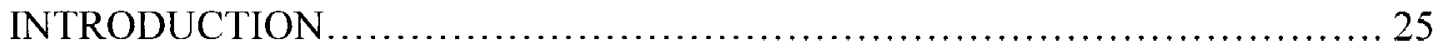

MATERIAL AND METHODS..................................................... 29

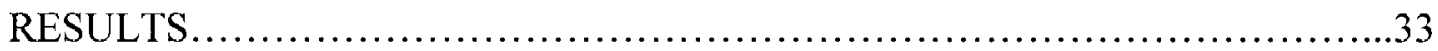

SA-4-1BBL inhibits antigenic conversion...............................33

SA-4-1BBL inhibits TGF- $\beta$ mediated conversion........................ 35

Cytokines milieu established by 4-1BB signaling control the conversion......36

SA-4-1BBL inhibits tumor mediated conversion..........................37

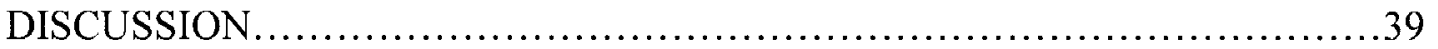

3. IMMUNOMODULATORY FUNCTION OF SA-4-1BBL AND RAPAMYCIN ON CONVERSION

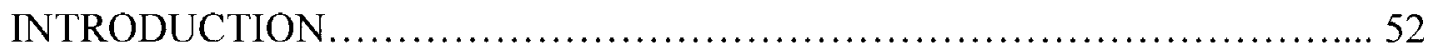

MATERIAL AND METHODS................................................. 56

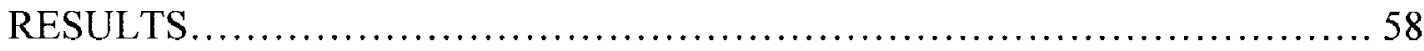


Rapamycin and IL-2 work in synergy to generate iTreg cells from alloreactive $\mathrm{CD}^{+}$Teff cells............................................. 58

4-1BBL in the presence of IL-2 and rapamycin further increase the percentage of $\mathrm{CD} 25^{+} \mathrm{FoxP}^{+} \mathrm{T}$ cells................................ 58 4-1BB but not CD28 signaling is crucial for rapamycin mediated increase in Treg cell enrichment.

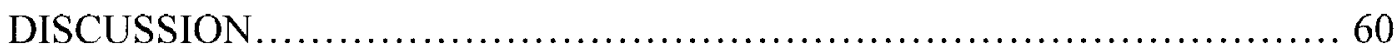

4. CONCLUSIONS AND FUTURE PERSPECTIVES .................... 66

REFERENCES........................................................ 71

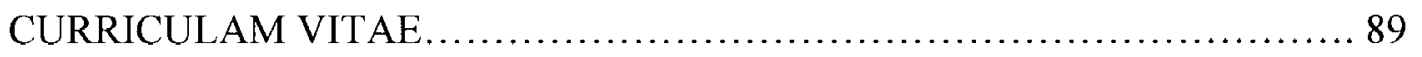




\section{LIST OF FIGURES}

FIGURE

PAGE

1. Thymic and peripheral generation of regulatory $\mathrm{T}$ cells......................... 22

2. 4-1BB signaling on Thymic nTreg cells and peripheral iTreg cells............... 23

3. Opposing functions of rapamycin on Treg and Teff cells ..................... 24

4. Outline of in vitro conversion of naïve $\mathrm{CD} 4^{+} \mathrm{T}$ cells into $\mathrm{FoxP}^{+} \mathrm{T}$ cells............. 43

5. 4-1BBL inhibits the conversion of naïve CD4 T cells into $\mathrm{CD} 25^{+} \mathrm{FoxP} 3^{+} \mathrm{T}$ cells... 44

6. 4-1BBL suppresses expression of FoxP3 induced by exogenous TGF- $\beta \ldots \ldots \ldots . \ldots 6$

7. 4-1BBL suppression of FoxP3 induction is mediated by IFN- $\gamma \ldots \ldots \ldots \ldots \ldots \ldots \ldots . \ldots 7$

8. SA-4-1BBL blocks the accumulation of iTreg cells in spleen and dLN ...........50

9. SA-4-1BBL blocks the accumulation of CD4 ${ }^{+}$FoxP3.gfp ${ }^{+} \mathrm{T}$ cells in tumor........ 51

10. Low dose rapamycin in the presence of IL-2 is effective in increasing the

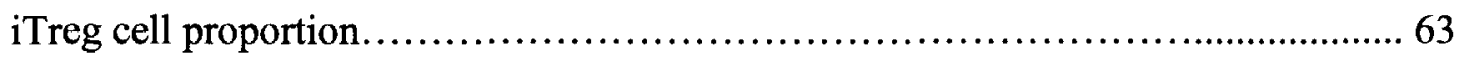

11. Synergy between SA-4-1BBL and IL-2 in increasing the iTreg cell proportion.... 64

12. $4-1 \mathrm{BB}$ but not $\mathrm{CD} 28$ costimulation is effective in increasing the iTreg cell Proportion

13. Schematic diagram showing the possible roles played by Treg cells in various disease setting and potential interventions by targeting Treg cells 


\section{CHAPTER 1}

\section{INTRODUCTION}

Regulation of immune system is of profound importance to host survival. In settings of autoimmunity or cancer, control is lost, resulting in hyper or hypo activation of immune system respectively. Suppression of deleterious immunity to normal selfantigens in autoimmune diseases, establishment of immunological tolerance to allogeneic transplants and reversal of the unresponsive state and enhancing immune responses to autologous tumor cells or chronic infections are essential for effective immunotherapy. Regulatory $\mathrm{T}$ (Treg) cells play an essential role in the establishment and maintenance of peripheral tolerance (1). There is now convincing evidence that defect in the numbers and/or function of Treg cells can lead to autoimmunity and graft rejection, whereas an excess of Treg cells can inhibit anti-tumor and anti-pathogen immunity (1-8). Therefore, there is an immediate need for the development of immunomodulatory approaches that can promote expansion of Treg cells in the context of autoimmunity and transplantation and also inhibit the expansion and/or suppressive function of Treg cells in the context of cancer and chronic infections. Signaling pathways required for the regulation of Treg cells might represent efficient targets for designing Treg cell-based immumodulatory approaches for the treatment of these diseases.

These are signal 1 delivered via $\mathrm{T}$-cell receptor (TCR) and major histocompatibility complex (MHC) molecules/peptide interactions, which needs 
to be accompanied by costimulation delivered via CD28 receptor family (9). Treg cells than get activated and need cytokines, particularly IL-2, for expansion and acquisition of effector function (10). A series of recent studies, including those from our laboratory, have demonstrated that several members of the tumor necrosis receptor (TNFR) family can provide costimulation to Treg cells for their expansion and survival (11-13). In particular, we demonstrated that costimulation via $4-1 \mathrm{BB}$ receptor has diverse functions on Teff and Treg cells with therapeutic implications in cancer, transplantation, and autoimmunity (12-16). Thus the aim of this dissertation is to exploit $4-1 \mathrm{BB} / 4-1 \mathrm{BBL}$ signaling as a novel immunomodulatory approach for manipulating Treg cells in an attempt to modulate immune responses in cancer and transplantation settings. The rationale for focusing on $4-1 \mathrm{BB} / 4-1 \mathrm{BBL}$ pathway is because of its critical role in regulating both $\mathrm{T}$ effector (Teff) and Treg cell responses that can be tuned for the treatment of disease. In the case of cancer or infectious diseases, preferential reduction of Treg cell numbers and/or blocking their function may enhance antitumor/pathogen immunity. However, in case of transplantation, preferential augmentation of Treg cell numbers and/or function may help suppress autoimmune responses and facilitate the establishment of tolerance to allogeneic antigens.

\section{Regulatory $\mathbf{T}$ cells}

The primary function of the immune system is to protect the body from foreign pathogens. This requires the immune system to recognize a countless number of antigens along with its ability to differentiate between self and non-self (17). Thymus plays a critical role in generating an extensive repertoire of $\mathrm{T}$ cells to recognize these antigens by positive selection based on TCR avidity (18). Along with that, a passive central tolerance 
mechanism also exists in the thymus where self reactive cells are deleted by a process called clonal deletion or negative selection (19). However, self reactive $\mathrm{T}$ cells escape into the periphery and exist in healthy individuals without causing autoimmune diseases. This is because several regulatory mechanisms, such as clonal deletion (20), anergy (21) and suppressive cytokines (22) exist in the periphery to keep in check the pathogenic selfreactive T cells.

In addition to these acquired peripheral tolerance mechanisms, the presence of natural tolerance through a $T$ cell population called naturally occurring $T$ regulatory (nTreg) cells, identified by the expression of CD4 and FoxP3 markers, has been established (1). These cells play a critical role in self tolerance as demonstrated by the presence of severe and uncontrolled autoimmunity in mice and patients that lack these cells (23-27). Although the primary function of these cells in the periphery is to control self-reactive pathogenic Teff cell function and collateral damage as a result of uncontrolled immune responses to infections, thereby contributing to immune homeostasis, a series of published evidence indicate that Treg cells can contribute to disease by either positively or negatively affecting the ongoing immune responses such as in cancers and autoimmunity, respectively $(3,5,7,28-36)$.

nTreg cells are selected and generated in the thymus through high avidity interactions between MHC class II and TCR (10, 37-42). The first evidence that $\mathrm{nTreg}$ cells are selected in the thymus came from studies demonstrating the existence of a subset of $\mathrm{CD}_{25}{ }^{+}$cells in the CD4 single-positive thymocyte compartment in thymus of both humans and mice (43-45). These $\mathrm{CD} 25^{+} \mathrm{CD} 4^{+}$thymocytes were capable of suppressing the function of Teff cells in vitro as well as in vivo in adoptive transfer models (43). Importantly, these cells under normal physiological conditions also exhibited increased 
expression of various activation markers, such as CTLA-4, GITR, Fas, and OX-40 (44, 46) that are normally expressed on activated Teff cells, suggesting that Treg cells may always be in a semi-activated phenotype, plausibly due to constant control of potential autoreactive effector peripheral mechanisms.

TCR signaling is indispensable for $\mathrm{T}$ cell lineage commitment of Treg cells during their development in the thymus. The role of TCR in the development of Treg cells is best demonstrated by the finding that TCR-transgenic mice on $\mathrm{RAG}^{-1-}$ background (recombination-activating gene-deficient mice which lack endogenous TCR rearrangements) do not develop Treg cells, whereas most TCR-transgenic mice on nonRAG $^{-/-}$background develop Treg cells $(18,47)$. Apart from TCR signaling, costimulatory signals mediated by $\mathrm{CD} 28 / \mathrm{CD} 80$ or $\mathrm{CD} 86$ are important in determining the repertoire and size of the Treg cell compartment in the periphery even though this signaling is not required for their function (9). Mice lacking either CD28 or CD80 and CD86 have decreased Treg cells in the periphery (9). This decreased Treg cell compartment is attributed to the direct role of $\mathrm{CD} 28$ signaling on thymocyte development of Treg cell and also due to diminished peripheral IL-2 produced by $\mathrm{T}$ cells in the absence of CD28 costimulation (48). Apart from TCR and CD28 signaling, dependence of Treg cells on IL-2 has been linked to their development, maintenance, survival and expansion of the Treg cell population (49). Deficiencies in either IL-2 or IL-2R is manifested by severe autoimmune disorders marked by excessive lympho proliferation (50). However, adoptive transfer of splenic or thymic $\mathrm{CD}^{+} \mathrm{T}$ cells from IL-2-deficient mice, but not from CD25-deficient mice, into a TCR-transgenic model of experimental allergic encephalomyelitis (EAE) showed that these Treg cells can protect from developing EAE. Thus, it suggests that Treg cell can development and undergo lineage 
commitment in the thymus in the absence of IL-2. However, signaling through IL-2 receptor is essential for their activity.

Both humans and mice develop a fatal autoimmune disorder (immune dysregulation, polyendocrinopathy, enteropathy, X-linked - IPEX in humans and scurfy in mice) due to mutations in the gene encoding FoxP3 transcription factor, strengthening the importance of this molecule in the development/function of Treg cells $(24,27,51$, 52). In humans, this immune disorder is marked by massive lymphoproliferation, onset of Type 1 Diabetes, thyroiditis and food allergies. Additionally, some patients develop other autoimmune pathologies like hemolytic anemia and thrombocytopenia, eczema, severe enteropathy as well as severe infections (51). Scurfy mutant mice lacking functional FoxP3 do not develop Treg cells and show various autoimmune pathologies $(53,54)$. FoxP3 protein belongs to a family of transcription factors that display a similar domain called winged helix-forkhead DNA-binding domain (forkhead box - Fox). FoxP3 transcriptional factor bind to the promoter DNA of various genes, acting as a transcriptional regulator (most suppressor) for various cytokines such as IL-2, IL-4 and TNF (55). In the absence of other cell surface molecules that are specific for Treg cells, FoxP3 expression is used as the sole marker for the identification of Treg cells for mice. However, this is not the case for human as newly activated human Teff cells also transiently express FoxP3 (56-60) and as such the identification of human Treg cells require testing their suppressive function for confirmation.

The role of nTreg cells in the maintenance of peripheral tolerance has been extensively studied. This is illustrated by spontaneous development of autoimmune diseases by the depletion of Treg cells in normal animals and restoration of these cells in turn prevents the development of the disease $(1,61)$. For example, Treg cell depleted 
spleen cells from normal mice cause spontaneous autoimmune disease in multiple organs following adoptive transfer into syngeneic T-cell-deficient hosts (62-64). Functional/physical elimination of Treg cells in setting of cancer has therapeutic implications (34). For example, depletion of $\mathrm{C}^{+} \mathrm{CD} 25^{+} \mathrm{T}$ cells before tumor challenge is effective in eliciting potent tumor specific immunity in vivo along with the development of various autoimmune diseases (34). Thus, nTreg cells are not only effective in inhibiting autoimmunity but also block/suppress a variety of physiological and pathological immune responses to non-self antigens that manifest in acquired diseases.

In recent years, it became evident that in addition to nTreg cells that are generated in the thymus, another population of $\mathrm{CD}^{+} \mathrm{FoxP}^{+} \mathrm{T}$ cells with regulatory function develop from the conversion of naïve $\mathrm{CD}^{+} \mathrm{T}$ cells outside the thymus under various settings (65-67). This so called adaptive or induced (iTreg) cells behave in a similar manner to the nTreg cells in suppressing immune responses. The first set of evidence for the existance of this cell type came from adoptive transfer experiments where naïve $\mathrm{CD}^{+} \mathrm{CD} 25^{-} \mathrm{T}$ cells were transferred to lymphopenic mice or mice devoid of nTreg cells $(50,68)$. During the homeostatic expansion of the transferred cells, part of the population acquired FoxP3 expression and suppressive function. Induction of iTreg cell in vivo by foreign antigens was also shown in mice treated with minute antigen doses (65). iTreg cells can also be induced in vitro from naive $\mathrm{CD}^{+} \mathrm{T}$ cells, particularly in the presence of TCR stimulation and TGF- $\beta$ and IL-2 cytokines $(66,69)$. Thus, it is clear that naive $\mathrm{CD}^{+} \mathrm{T}$ cells selected as $\mathrm{FoxP}^{-}$in the thymus have full potential to become Fox $3^{+}$iTreg cells in vivo and in vitro (Figure 1). These cells are critical to acquired 
peripheral tolerance as well as exploited for immune evasion by cancer and infections or experimentally for tolerance to auto and alloantigens for therapeutic purposes.

\section{Generation of iTreg cells}

Unlike nTreg cells, which develop in a highly controlled thymic microenvironment (70), generation of iTreg cells may vary based on the environmental cues or conditions. Initial evidence of peripheral conversion came from adoptive transfer experiments where sorted polyclonal naïve $\mathrm{CD}^{+} \mathrm{CD} 25^{-} \mathrm{T}$ cells transferred into lymphopenic mice or TCR transgenic mice on $\mathrm{RAG}^{-/-}$background, which lack nTreg cells, were shown to convert into FoxP3 expressing iTreg cells $(50,68)$. Under those settings, where homeostatic proliferation of the transferred cells was possible, part of the donor population became $\mathrm{CD}_{2} 5^{+}$and $\mathrm{FoxP}^{+}$and they also expressed Treg cell specific markers CTLA-4 and GITR along with their suppressive capability. In a different setting, transfer of antigen-specific naive $\mathrm{CD} 4{ }^{+} \mathrm{T}$ cells into lymphocyte-deficient $\mathrm{RAG}^{-/ .}$mice that expressed the antigen as a systemic secreted protein resulted in acute immune response from transferred cells towards the recipient. This was followed by a tolerogenic phase that is associated with iTreg cell generation (71). This iTreg cell generation did not require the thymus but was dependent on IL-2. Although the precise developmental requirements of iTreg cell generation in vivo is still incomplete, some studies successfully generated iTreg cells in vivo by treating mice with low doses of antigen cross-linked to DEC-205 Ab (targets antigens specifically to DCs) and delivered by osmotic pump. Conversion of $\mathrm{CD}^{+} \mathrm{CD} 25^{-} \mathrm{T}$ cells into iTreg cells was also shown in another adoptive transfer model where sorted CD4 cells were transferred into irradiated mice (72). Under 
these lymphophenic conditions, these cells readily underwent conversion and this was independent of thymus, but was dependent of CD28 signaling.

In vitro generation of iTreg cells requires both TCR stimulation and the cytokines TGF- $\beta$ and IL-2 are absolutely required for naïve $\mathrm{CD}^{+}$effector cells to convert into iTreg cells. During TCR-stimulation, addition of TGF- $\beta$ to naive $\mathrm{CD}^{+} \mathrm{T}$ cells cultures induces the expression of FoxP3 (66) and the mechanism involves cooperation of the transcription factors STAT3 and NFAT at a FoxP3 gene enhancer element $(69,70)$. Addition of TGF- $\beta$ along with CD3 and CD28 stimulation to naive $\mathrm{CD}^{+} \mathrm{T}$ cells induced the generation of iTreg cells which were anergic and suppressive in vitro and in vivo as shown by their ability to suppress inflammation in an experimental asthma model (66). As discussed in the nTreg cells section, IL-2 is dispensable for the generation of nTreg cells in the thymus. However, for in vitro generation of iTreg cells, IL-2 is required. Studies done by neutralization IL-2 in the cultures or using IL-2-deficient T cells demonstrated that IL-2 is required for in vitro for induction of FoxP3 mediated by TGF- $\beta$ (73). IL-2 signaling is required for the activation of STAT5, which in turn binds to FoxP3 gene enhancing its expression. Costimulatory signal mediated by CTLA-4 is dispensable for thymic generation of nTreg cells (74). However, upregulation of CTLA-4 is required for TGF- $\beta$ mediated expression of FoxP3 in naïve $\mathrm{CD} 4^{+} \mathrm{T}$ cells and also for suppressive activity of converted iTreg cells (74).

\section{Differences between nTreg and iTreg Cells}

There has been some disagreement on whether in vitro generated iTreg cells are as good suppressor cells as nTreg cells $(28,33,66,75-77)$. The functional difference between 
nTreg cells and iTreg cells looks to arise from the methylation of CpG motifs in the FoxP3 locus where nTreg cells have complete demethylation upstream of exon 1 and is unique to $\mathrm{FoxP}^{+}$Treg cells. In contrast to nTreg cells, in vitro generated iTreg cells display partial demethylation even though they have high FoxP3 expression (78). These in vitro generated iTreg cells, but not nTreg cells, lost both FoxP3 expression and suppressive activity when restimulated in the absence of TGF- $\beta(79,80)$. A marked difference in the methylation state of iTreg cells generated in vitro and in vivo is that in vivo iTreg cells generated by administration of antigen displayed efficient demethylation (78) and are effective suppressors as compared to in vitro generated iTreg cells $(65,71$, 81-83). Using gene profiling, studies have defined pool of genes that are specifically expressed in nTreg cells. Some of these genes are regulated independently by FoxP3 and some of them are repressed or induced exclusively by FoxP3 (76). Comparing this subset of genes that are either upregulated or downregulated between nTreg cells and iTreg cells showed that in vitro generated iTreg cells did not display some of the nTreg cell signature genes (76).

As iTreg cells are generated in the periphery from naïve $\mathrm{CD}^{+} \mathrm{T}$ cells, nTreg and iTreg cells might have potential differences in terms of TCR repertoire, differentiation and their mode of action. Studies have indicated that iTreg cells mediate their inhibitory function by producing immunosuppressive cytokines like TGF- $\beta$ and IL-10 $(84,85)$. Contrastingly, nTreg cells are shown to function by direct cell-cell interactions with responding T cells or APCs and this mechanism is cytokine-independent (86). 


\section{iTreg cells and Cancer}

Recent progress in understanding the ability of innate and adaptive immune responses against tumors has strengthened the concept of immunosurveillance. For example, the incidences of tumor in immune-incompetent individuals either via acquired genetic defects or experimental/therapeutic manipulations are significantly higher than individuals with normal functions (87). Most importantly, a recent study has demonstrated using a spontaneous mouse model of melanoma that tumor cells disseminate throughout the body early in development of the primary tumor and stays dormant for varying periods of time depending on the tissue. Most importantly, dormancy in the lung was associated with reduced proliferation of the disseminated tumor cells by CD8 $+\mathrm{T}$ cells as physical elimination of these immune cells resulted in accelerated tumor growth (88). Irrespective of active immunosurveillance, tumors grow in immune-competent individuals suggesting that immune system and tumors exist in an equilibrium state. This is primarily due to the ability of tumors to exploit various immune evasion mechanisms for growth and progression. This is evidenced by studies demonstrating the presence of tumor-specific and activated both $\mathrm{CD} 4^{+}$and $\mathrm{CD} 8^{+} \mathrm{T}$ cells in cancer patients without functional consequences with respect to clinical disease (89). These observations suggest that immune system in patients with cancer is constantly on attack, but there are other counter-attack mechanisms that tilt the balance towards immune inactivation and tumor progression.

Tumors employ multiple mechanisms for evading $\mathrm{T}$ cells responses. Some of these include alterations of components of the antigen presentation machinery, secretion of inhibitory factors, activation of negative regulatory pathways, and recruitment of Treg 
cell populations (90-93). Treg cells represent one of the most dominant immune evasion mechanisms employed by tumors for progression. Increased numbers of Treg cells in tumor tissue and/or peripheral blood of patients with various cancers have been reported $(2,4,35,94,95)$ and this is associated with poor prognosis and survival (2). Dominant role of Treg cells in immune evasion mechanisms is evident from various experimental tumor models, where depletion of these cells or modulation of their function significantly improved the therapeutic efficacy of the vaccines $(36,96-98)$. Blocking antibodies against some of the signature costimulatory molecules expressed by Treg cells like CTLA-4 and GITR were able to induce potent antitumor immunity and this was associated with increased number of tumor-specific interferon- $\gamma$-secreting $\mathrm{CD}^{+}$and $\mathrm{CD}^{+} \mathrm{T}$ cells in the spleen $(98,99)$. Strikingly, a combination of blocking antibodies against both CTLA-4 and GITR synergistically enhanced anti-tumor responses and was able to eradicate more advanced tumors in mice (98). Tumors are known to suppress immunity by promoting the chemokine mediated recruitment followed by cytokine mediated expansion, and activation of Treg cells (100). This specific recruitment of Treg cells results in the inhibition of effector $\mathrm{T}$ cell activation, immune escape, and ultimately tumor progression (3). Interestingly, many tumors are known to produce cytokines such as IL-10 and TGF- $\beta$, which promote the proliferation of nTreg cells, and as well as the conversion of CD4 $\mathrm{T}$ cells into iTreg cells $(3,101,102)$. Conversion of naive CD4 $\mathrm{T}$ cells into iTreg cells and their accumulation in tumor sites $(5,103)$ also play a key role in obstructing tumor immunosurveillance and cancer immunotherapies $(8,103)$. In one study, it has been reported that cyclooxygenase (COX)-2 and its product prostaglandin play an important role in the pathogenesis of non-small cell lung cancer (104). COX-2 along with its product, prostaglandin produced by tumors induced the 
expression of FoxP3 in T cells, and consequently increased Treg cell activity in the tumor (105). Furthermore, inhibition of COX-2 reduced Treg cell frequency and activity in the tumor and attenuated FoxP3 expression in tumor infiltrating lymphocytes along with decreased tumor burden. The effective approach for cancer immunotherapy will depend on the identification of unique cell surface receptors or ligands that can greatly enhance the effector responses against cancer but also inhibit the suppressive function of Treg cells and also conversion of naïve $\mathrm{CD}^{+} \mathrm{T}$ cells into iTreg cells. In this context, signaling via the members of TNFR costimulatory molecules may have the potential to control the function as well as generation of iTreg cells in settings of vaccines with potential therapeutic efficacy.

\section{iTreg cells and transplantation}

In the last two decades transplantation of organs, tissues, or cells between genetically non-identical individuals has become a routine therapeutic option for many disorders such as organ failure, cancers and other hematological malignancies. However, transplantation of allogeneic tissue is associated with secondary diseases arising from graft-versus-host (GVH), in case of bone marrow cell transplant or transplantation of tissues rich in mature lymphocytes, or host-versus-graft (HVG), in case of all foreign transplants, immune responses. These responses develop when immune cells of the graft or recipient recognize allogeneic histocompatibility antigens and mount an immune attack against the recipient or donor, respectively. During this activation, proliferation of effector cells along with the release of proinflammatory cytokines result in tissue damage (106). The discovery of immunosuppressive drugs for the prevention of GVH and $\mathrm{HVG}$ 
immune responses, paved the way for the clinical use of allogeneic transplantation as a curative modality for treating various disease states.

Despite this accomplishment, GVH disease, graft rejection, and opportunistic infections due to prolonged nonspecific immunosuppression following transplantation remain the major hindrance limiting the efficacy of allogeneic transplantation. Studies show that allogeneic graft rejection (HVG) can be mediated by host $\mathrm{CD}^{+}$and $\mathrm{CD}^{+} \mathrm{T}$ cells (107), NK cells (108), NKT cells (109) and $\gamma \delta \mathrm{T}$ cells (110, 111) that can recognize histocompatibility antigens of the donor cells. In order to overcome this, patients are treated with immunosuppressive drugs such as calcinurin and mammalian target of rapamycin (mTOR) inhibitors. Whereas, GVHD requires that the graft contain immunocompetent cells before transplantation, and there must be histocompatibility differences in antigens between host and the donor which will ultimately lead to donor immune response to host. Both $\mathrm{CD} 4^{+}$and $\mathrm{CD} 8^{+} \mathrm{T}$ cells mediate the effector pathway in the onset of GVHD and HVGD using multiple direct, such as killing of target via mechanisms perforin and FasL (112), or indirect mechanisms, such as proinflammatory cytokines, delayed type hypersensitivity reactions, generation of humoral immunity.

To overcome complications associated with allogeneic transplantation and permit engraftment, recipients and grafts undergo a series of conditioning procedures. The primary purpose of this conditioning is to suppress host immunity to prevent graft rejection by reducing the immunocompetent cells. To this purpose, hosts are treated with myeloablative drugs and total body irradiation that are cytotoxic in nature (113). Following transplantation, recipients are treated chronically with immunosuppressive agents to prevent graft rejection as well as control GVHD. Use of cytotoxic conditioning 
and immunosuppressive drugs are often associated with toxicity and side effects reducing the efficacy of transplantation and decreasing the overall survival (114). Therefore, the development of novel immunosuppressive regimens with minimal/tolerable toxicity is of critical importance and focus of the transplantation field.

The activities of Treg cells are now recognized as fundamental to the development and maintenance of immune tolerance and shown to inhibit alloreactive Tcell activation and effector cell function $(6,115)$, serving as an attractive therapeutic tool for inducing tolerance against transplanted grafts $(116,117)$. Despite decades of research into the phenotypes and functions of different subsets of Treg cells, only recently have they been sufficiently well characterized to begin considering how they might be targeted therapeutically. There are numerous reports that by manipulating the numbers and/or function of Treg cells in mice, we can decrease pathology in a wide range of contexts, such as autoimmunity and transplantation. Transplantation in sublethally conditioned mice along with donor Treg cell infusion was shown to prevent graft rejection and suppress the onset of acute GVHD $(30-32,118,119)$. Conversely, depletion of Treg cells from either graft or recipients following transplantation enhances the rate of graft rejection and development of GVHD $(31,118)$. Treg cells are present in relatively low frequencies in lymphoid organs. For efficient use of Treg cells for inducing tolerance in transplantation setting, studies have focused on developing strategies for both ex vivo and in vivo expansion of Treg cells (7). In some settings, both ex vivo expansion of Treg cells and subsequent activation of Treg cells to increases their suppressor cell potency was shown to inhibit the onset of GVHD (119). Although expansion strategies that can target in vivo expansion of Treg cells will be safer and clinically relevant, they remain to be developed. 
Many transplantation protocols require use of immunosuppressive agents like calcineurin inhibitors cyclosporine $\mathrm{A}$ and $\mathrm{mTOR}$ inhibitor, rapamycin. These immunosuppressive agents influence the Treg cell expansion strategies as they have both negative and positive effects on Treg cells. For example, calcineurin inhibitors block the production of IL-2, in turn reducing the Treg cell proliferation, function and expansion due to their critical dependence on IL-2 (120). There the use of calcineurin inhibitors are associated with nonspecific suppression of both Teff and Treg cells with the requirement of continuous use in the patients with long-term adverse consequences. Therefore the use of such nonspecific immunosuppressant has recently been called into question for the ultimate goal of achieving clinical transplantation tolerance. Therefore, there is an intense interest in developing immunosuppressive drugs that preferentially inhibit the function of Teff cells with no or positive effects on Treg cell development and function. Rapamycin, a mTOR inhibitor, appears to suffice this promise.

Rapamycin is a potent immunosuppressant and an inhibitor of $\mathrm{T}$ cell proliferation. It acts on a serine/threonine protein kinase (mTOR) that has an important immunomodulatory function in both innate and adaptive immune responses. mTOR plays a crucial role in cell growth and proliferation, transcription, translation, ribosomal synthesis, and cytoskeleton organization (121). Rapamycin is produced by Streptomyces hygroscopicus and was first identified as a potent antifungal agent (122). Later it was found to exhibit potent immunosuppressive activity and inhibit cell proliferation. It is currently used as an immunosuppressive drug in renal transplantation (123) and for the prevention of graft rejection and GVHD in various transplantation settings $(124,125)$. It is also used as a chemotherapeutic agent for treatment of various cancers (126). 
Unlike other immunosuppressive agents in the context of transplantation, rapamycin has two fold advantage that it not only suppresses the proliferation of $\mathrm{T}$ cells, but also helps the generation of iTreg cells and does not affect the proliferation of nTreg cells (127), indicating that Treg cells are not prone to mTOR inhibition. Unlike other immunosuppressive agents, rapamycin does not alter the immunosuppressive ability of Treg cells in in vitro cultures (128). In vivo administration of rapamycin results in increased Treg cells numbers compared to $\mathrm{CD}^{+}$Teff cells $(128,129)$. In addition, rapamycin in combination with IL-2 was effective in selectively expanding Treg cells from a mixed $\mathrm{CD}^{+} \mathrm{T}$ cell population in vitro (130). In another study, the observation that stimulating $\mathrm{CD}^{+} \mathrm{T}$ cells in the presence of rapamycin results in induction of suppressor functions in conventional $\mathrm{CD}^{+} \mathrm{T}$ cells offered an explanation that rapamycin not only promotes survival and function of nTreg cells, but also induces FoxP3 expression in $\mathrm{CD}^{+} \mathrm{T}$ cells by converting them into iTreg cells (131). TGF- $\beta$ induces FoxP3 expression through the activation of the transcription factor SMAD3 (mothers against decapentaplegic homologue 3 ), which in combination with NFAT binds to the enhancer region of FoxP3, ultimately resulting in its transcription (132). Under physiological conditions, signaling through mTOR results in inhibition of SMAD3 activation in Teff cells (133), which can be inhibited by rapamycin, leading to the activation of SMAD3 and expression of FoxP3. Now the cause of a generalized increase in the frequency of Treg cells in the presence of rapamycin can be interpreted as a result of two effects: 1) the ability of nTreg cells to expand in the presence of rapamycin, and 2) the promotion of FoxP 3 expression in $\mathrm{CD}^{+} \mathrm{T}$ cells. Rapamycin, therefore, is viewed as a tolerogenic drug that can be used in combination with other therapeutic approaches in transplantation and autoimmune diseases aimed at inducing Treg cells. Particularly, the 
ability of rapamycin to suppress the function of Teff cells not only is important for the generation of a time window required for the generation of regulatory mechanisms, but also serves to suffice the FDA requirement for the use of standard immunosuppression for transplant patients. The dual ability of rapamycin to suppress the function of Teff cells and facilitate the generation of Treg cells makes it as the drug of choice for immunomodulation. Most importantly, rapamycin also has immunoregulatory functions on antigen-presenting cells, such as DCs (134), further enhancing its use for the generation of tolerance.

\section{4-1BB/4-1BBL signaling pathway and immune regulation}

The specificity of $\mathrm{T}$ cells responses are controlled by a series of orchestrated signaling pathways. First, the engagement of TCR with $\mathrm{MHC} / \mathrm{Ag}$ complex determines the specificity of the immune response (135). However, other signals such as costimulation (CD28-B7) and cytokines (IL-2) are required for full activation of T cells (135). In the absence of these signals, $T$ cells usually undergo antigen specific immune down regulation, called anergy (136). After the initial activation, T cells go on and differentiate into effector cells of which some will survive as long-lived memory T cells (137). After the initial activation, $T$ cells upregulate various members of the TNFR family costimulatory molecules and uses signaling via these receptors for survival, proliferation, expansion, and differentiation to acquire effector and long-term memory functions.

TNFR family members such as, CD27, CD134 (OX40), CD137 (4-1BB), HVEM, CD30, FAS and GITR play a direct role in $\mathrm{T}$ cell responses leading to initial $\mathrm{T}$ cell activation. TNFR members are divided into various groups based on the intracellular domains or factors that are associated with these receptors. For example, receptors like 
FAS are associated with death domains (DD) and signaling through these receptors activate the caspase cascade, ultimately leading to apoptosis (11). Importantly, some of the TNFR members such as $4-1 \mathrm{BB}$ and $\mathrm{OX} 40$ are associated with TNF receptor associated factors (TRAF) which play an important role in $\mathrm{T}$ cell activation, survival and differentiation $(11,138,139)$.

4-1BB (CD137, TNFSFR9) is a member of the TNF receptor family which was initially shown to play an important role as a costimulatory molecule for both $\mathrm{CD} 4^{+}$and $\mathrm{CD}^{+} \mathrm{T}$ cells (140). 4-1BB is expressed on activated $\mathrm{CD} 4^{+}$and $\mathrm{CD}^{+} \mathrm{T}$ cells thereby controlling their proliferation, survival and cytokine production $(141,142)$. Additionally, this receptor is also expressed by activated NK cells, neutrophils, eosinophils, subsets of immature/mature DCs in human as well as mice $(136,143-147)$. Its ligand, 4-1BBL is expressed by activated professional APCs $(143,148,149)$ as well as other non-immune cells such as smooth muscle cells and endothelial cells (150). Thus, regulation of T cell responses by $4-1 \mathrm{BB}$ signaling most likely occurs by the engagement of $4-1 \mathrm{BBL}$ on activated APCs with 4-1BB on activated T cells, ultimately resulting the activation of $\mathrm{T}$ cells, their survival, expansion, and conversion to effectors and long-term memory cells.

The engagement of 4-1BBL with 4-1BB may transduce the signal not only to $\mathrm{T}$ cells for immune activation, but also reverse signaling into APCs with both positive immune consequences. Reverse signaling through 4-1BBL can occur in DC, B cells, and monocytes $(151,152)$, suggesting the role of this signaling pathway on multiple cell types with multiple functions. The role of $4-1 \mathrm{BBL}$ reverse signaling is best illustrated in human DCs where 4-1BBL cross-linked on DCs with CD137-Fe led to DC maturation in a TNF- $\alpha$ dependent manner (153). Reverse signaling of 4-1BBL also up-regulated chemokine receptor CCR7, thereby mediating the migration of DC. Finally, CD137L- 
activated DCs were able to induce $\mathrm{T}$ cell differentiation and proliferation along with the production of proinflammatory cytokines IL-12 and IFN- $\gamma$. Most importantly, a recent report has demonstrated that reverse signaling converts human monocytes into functional DCs (154). Collectively, these data demonstrate that the 4-1BB/4-1BBL signaling system tunes the immune system at multiple effector cell types for the generation of effector immune responses to cancers and infections.

The kinetics of 4-1BB expression in vitro reveal that the expression on $\mathrm{T}$ cells peaks at about $48 \mathrm{hr}$ after primary $\mathrm{T}$ cell activation and declines again after 4-5 days $(140,155,156)$. However, in vivo analysis of $4-1 \mathrm{BB}$ expression reveals that its expression on $\mathrm{T}$ cells can be earlier, peaking at $12-36 \mathrm{hrs}$ and is more transient as compared to in vitro kinetics (157). This expression pattern coincides with the T cell activation kinetics and fall between the expression of activation markers, CD69 and CD44 (158). In addition to its role as an activation-induced costimulatory receptor on T cells (156), 4-1BB is also expressed constitutively on Treg cells $(159,160)$ with potential function of regulating the balance between Teff and Treg cells with important implications in health and disease.

The ability of costimulatory TNFR family members like $4-1 \mathrm{BB}$ to regulate both T cell and Treg cell activation, survival and differentiation at different stages in the immune response make these molecules potential targets for various immunomodulatory approaches for the treatment of various cancer and graft rejection and tolerance induction to autoantigens. The potential of $4-1 \mathrm{BB}$ as a target for immunomodulation in the cancer setting arises from the findings that it can greatly enhance the expansion of $\mathrm{CD}^{+}$and $\mathrm{CD}^{+} \mathrm{T}$ cells in vivo $(14,140,158,161)$ and its ability to make these cells to be refractory to Treg cell mediated immunosuppression $(12,159)$. We recently showed that 
when 4-1BBL was used as a component of vaccine against various tumor models increased the number of both $\mathrm{CD}^{+}$and $\mathrm{CD} 8^{+} \mathrm{T}$ effector as well as memory responses (15) along with a decrease in intratumoral Treg cells with therapeutic efficacy in various tumor models. It is not clear at this point how 4-1BB signaling leads to a better ratio of Teff/Treg cells within the tumor and lymphoid organs. Signaling via 4-1BB may preferentially expand Teff cells, actively inhibit the generation of iTreg cells, and/or preferentially cause Treg apoptosis. Regardless, our recently published studies in tumor setting using $4-1 \mathrm{BB}$ costimulation as a means of immunomodulation are exciting and further substantiate the importance of this pathway for modulating immune responses for therapeutic purposes.

The potential use of 4-1BB signaling as a target for immunotherapy in context of transplantation and autoimmunity arises from the constitutive expression of 4-1BB on Treg cells and the ability of signaling via this receptor to effectively expand nTreg cells ex vivo without losing their suppressive ability and FoxP3 expression $(12,162)$. Our laboratory has recently demonstrated that sorted nTreg cells constitutively express 4-1BB receptor and respond to IL-2 by upregulating the level of this receptor (12). Most importantly, Treg cells were expanded over 110 fold within a few weeks by periodic stimulation with low dose exogenous IL-2 and a chimeric form of 4-1BBL, SA-4-1BBL. The expanded cells had potent suppressor function on Teff cells as demonstrated in vitro. Importantly, adoptive transfer of the expanded Treg cells in a chemically diabetic allogeneic islet model resulted in effective prevention of graft rejection and glucose homeostasis (12). These findings along with the ability of rapamycin and IL-2 to expand nTreg cells and/or convert naïve $\mathrm{CD}^{+} \mathrm{T}$ cells into iTreg cells led us to hypothesize that targeting $4-1 \mathrm{BB}$ in the transplantation and autoimmunity settings in the presence of 
rapamycin may serve as a viable approach to expand Treg cells in vivo for immunotherapy.

In conclusion, 4-1BB signaling has great potential as an immunomodulatory approach to shift the balance between Teff and Treg cells for the treatment of diseases that can benefit from a predominant form of one of these cell types. Therefore, the main focus of this PhD study is to test the utility of 4-1BB signaling for either expanding or contracting Treg cell numbers in inverse correlation with the number of Teff cells with the ultimate goal of treating cancer, autoimmuity, and graft rejection. 


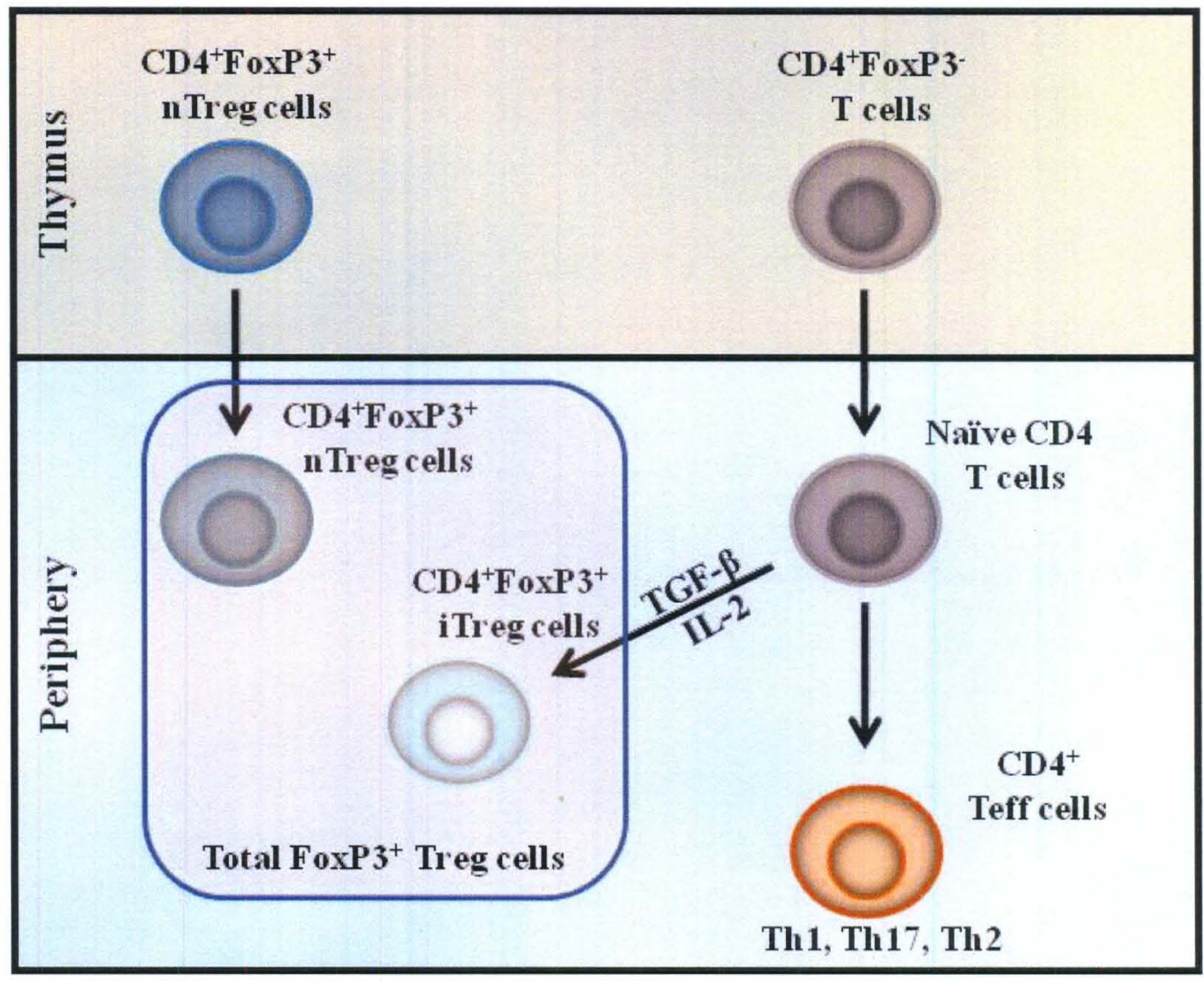

Figure 1. Development of nTreg and iTreg cells. nTreg cells are selected based on TCR-MHC interactions in the thymus and migrate to periphery for the control of autoimmunity. In marked contrast, iTreg cells are generated de novo in the periphery from conventional naïve $\mathrm{CD}^{+} \mathrm{T}$ cells. Although the precise mechanism responsible for the generation of iTreg cells is not well elucidated, TGF- $\beta$ and IL-2 appear to be play important roles. These Treg cells use various mechanisms to control the function of cells of adaptive and innate immunity for the establishment of tolerance. 


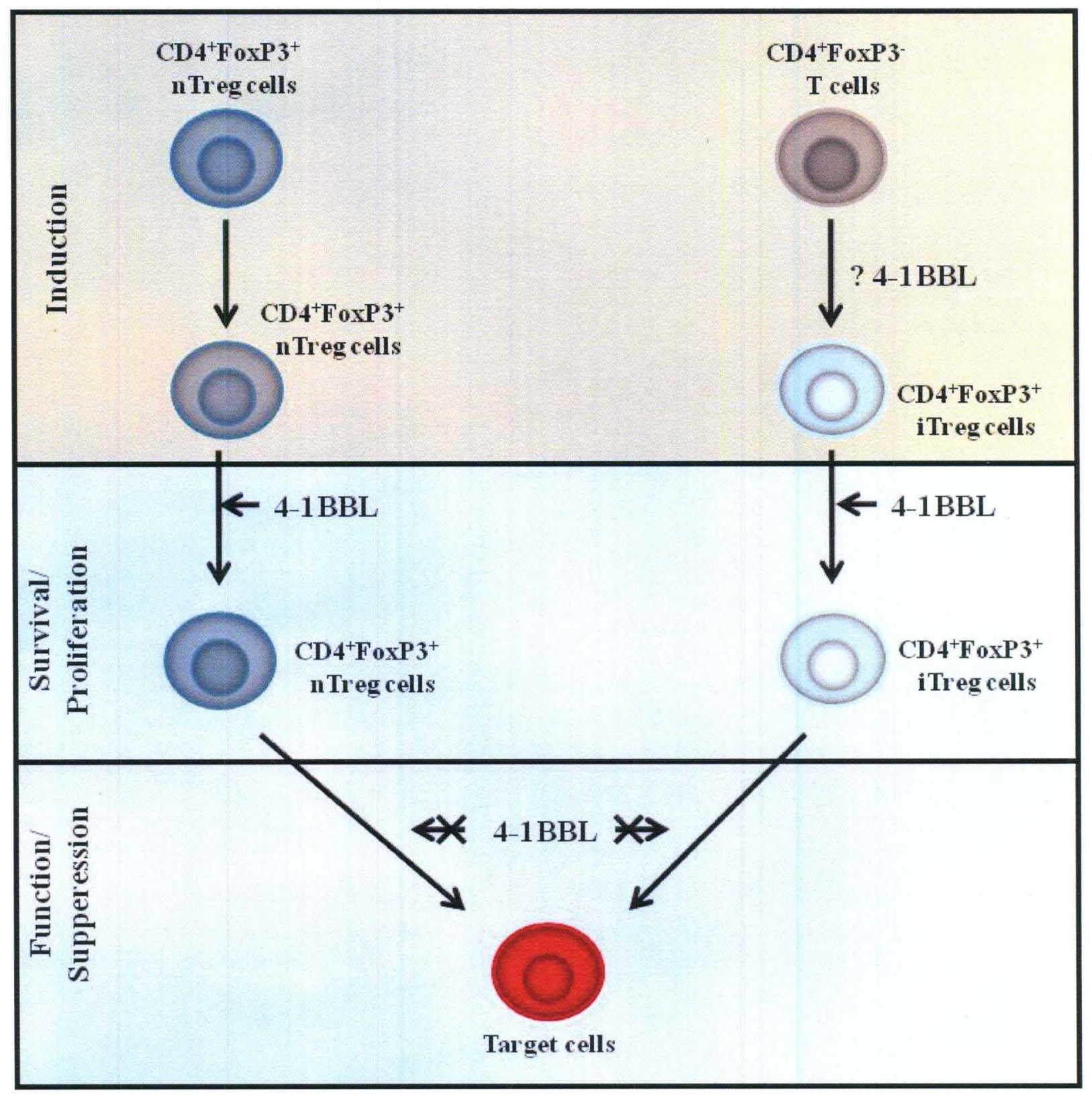

Figure 2. Pleiotropic effects of 4-1BB signaling on the regulation of development and function of nTreg and iTreg cells. The 4-1BB signaling contributes to the proliferation, expansion, and/or survival of already existing nTreg and iTreg, but inhibits the regulatory/suppressive function of these cells by endowing Teff cells resistant to suppression by Treg cells. The effect of signaling via 4-1BB on the generation of iTreg cells is not known. 


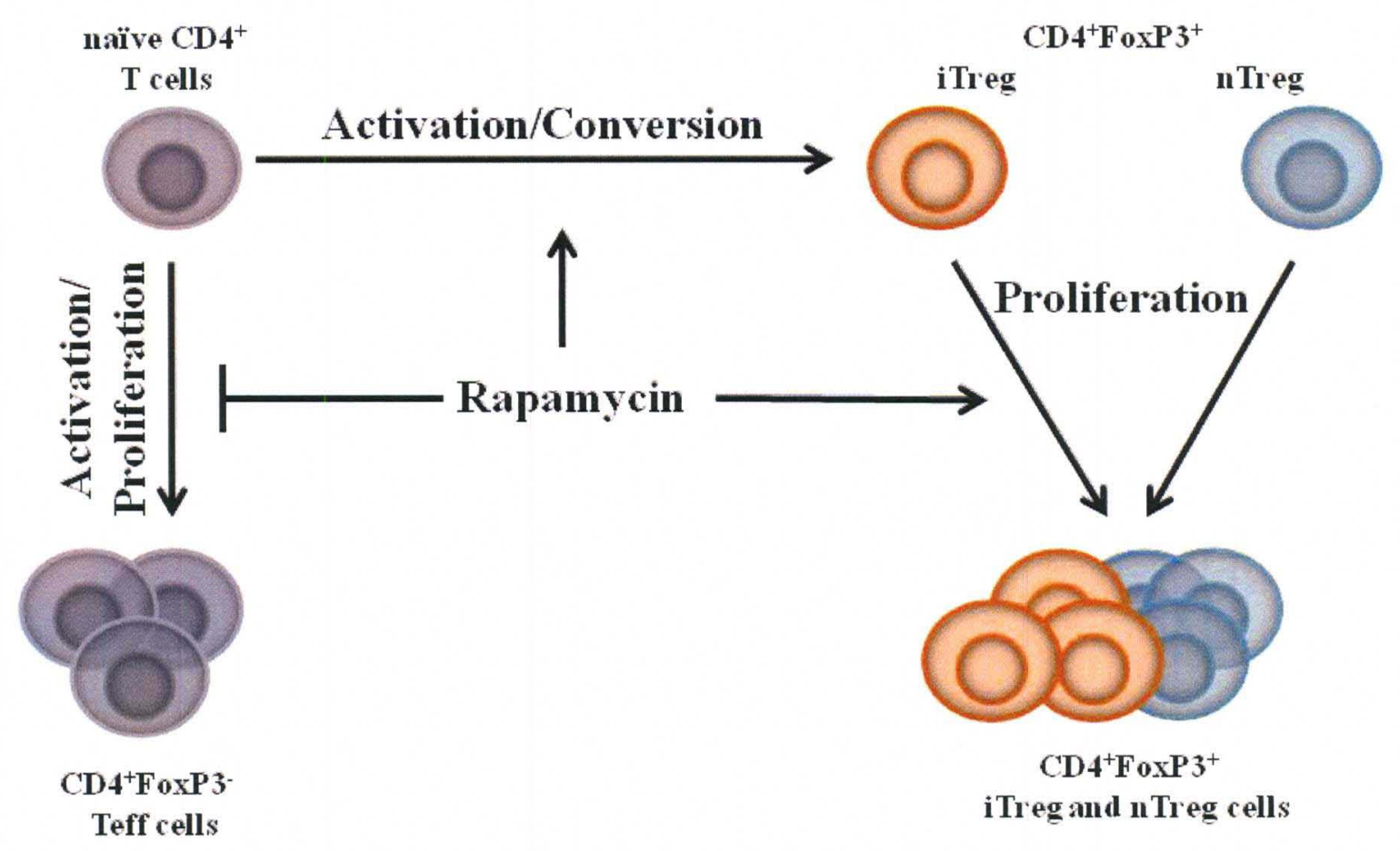

Figure 3. Opposing functions of rapamycin on Treg and Teff cells. Rapamycin inhibits the proliferation of activated $\mathrm{CD} 4^{+}$Teff cells through the inhibition of mTOR signaling pathway which is crucial for proliferation, transcription, translation, ribosomal synthesis, and cytoskeleton organization. Whereas rapamycin facilitates their conversion of activated $\mathrm{CD} 4^{+}$Teff cells into iTreg cells without a deleterious effect on the survival and expansion of iTreg and nTreg cells. Collectively, these effects result in tilting the balance towards Treg cells with positive treatment consequences in transplantation and autoimmune settings. 


\section{CHAPTER 2}

\section{IMMUNOMODULATORY FUNCTION OF SA-4-1BBL ON CONVERSION OF NAÏVE CD4 ${ }^{+}$T CELLS INTO $\mathrm{CD4}^{+} \mathrm{FoxP3}^{+} \mathrm{T}$ CELLS}

\section{Introduction}

Despite major breakthroughs in elucidating the effector mechanisms required for effective tumor immunity, a number of immune evasion mechanisms employed by cancers hinder the successful translation of mechanistic approaches into effective tumor immunotherapy. Such evasion mechanisms include the ability of tumors to induce a tolerogenic and immunosuppressive microenvironment and secretion of inhibitory factors which act synergistically to counteract effector immune responses. One such mechanism is the generation and/or preferential recruitment of Treg cells into the tumor or draining lymphoid organs. Treg cells play a dominant role in cancer immune evasion mechanisms as shown in various clinical $(4,94,95,163)$ as well as preclinical settings $(2,3)$. Tumors modulate immune responses $(2,35,95)$ either by recruiting and expanding preexisting nTreg cells (164) and/or by converting naive $\mathrm{CD}^{+}{ }^{-F o x P} 3^{-} \mathrm{T}$ cells into iTreg cells (165168). These Treg cells then suppress anti-tumor immune responses by targeting cells of innate, adaptive, and humoral immunity, such as CD4 and CD8 T lymphocytes, NK cells, and B lymphocytes, ultimately leading to tumor progression $(164,169,170)$. 
Although there are various types of $\mathrm{T}$ cells with regulatory functions, such as $\mathrm{CD}^{+}{ }^{+}$FoxP3- IL-10 secreting $\mathrm{Tr} 1, \mathrm{CD}^{-} \mathrm{CD}^{-} \mathrm{T}$ cells (171) as well as $\mathrm{CD}^{+}$Treg cells $(172,173), \mathrm{CD}^{+} \mathrm{FoxP}^{+}$Treg cells appear to play the most dominant role for immune regulation under normal physiological as well as disease settings. In humans and rodents, Treg cells constitute $5-10 \%$ of $\mathrm{CD}^{+} \mathrm{T}$ cell population and can be divided into two different types; natural and induced. Although processes involved in the generation of nTreg cells in the thymus are well defined, those for iTreg cells are not as extensive but include antigen, IL-2, TGF- $\beta$ and retinoic acid $(67,174,175)$. TGF- $\beta$ mediated signals are also required for the induction of iTreg cells that are differentiated by antigen from naïve CD4 $\mathrm{T}$ cells in the periphery. Of critical significance to this study, tumors employ some of these molecules for recruitment of $\mathrm{nTreg}$ cells or conversion of naïve $\mathrm{CD}^{+} \mathrm{T}$ cells into iTreg cells for evading immune surveillance $(2,4,176)$. Treg cells exert their suppressive function either directly through cell-cell contact or through soluble factor. Although the precise mechanism of suppression is still not clear, physical elimination (177) and inhibiting IL-2 production (178) needed by effector T cells, induction of regulatory DCs (179), inhibition of effector T cell proliferation through TGF- $\beta$ (29) and IL-10 (180) are some of the mechanisms used by Treg cells for exerting their suppressive activity.

The importance of Treg cells, both nTreg as well as iTreg, in immune evasion mechanisms employed by tumors has generated immense interest in efforts to reduce number or function of these cells for therapeutic interventions $(36,98)$. Tumors employ multiple mechanisms for evading $\mathrm{T}$ cell responses. Some of these include alterations of components of the antigen presentation machinery, secretion of inhibitory factors, activation of negative regulatory pathways, and recruitment of Treg cell populations (90- 
93). Tumors are known to suppress immunity by promoting the chemokine mediated recruitment followed by cytokine mediated expansion, and activation of Treg cells (100). This specific recruitment of Treg cells results in the inhibition of effector $T$ cell activation, immune escape, and ultimately tumor progression (3). Treg cells represent one of the most dominant immune evasion mechanisms employed by tumors for progression. Increased numbers of Treg cells in tumor tissue and/or peripheral blood of patients with various cancers have been reported $(2,4,35,94,95)$ and this is associated with poor prognosis and survival (2). Dominant role of Treg cells in immune evasion mechanisms is evident from various experimental tumor models, where depletion of these cells or modulation of their function significantly improved the therapeutic efficacy of the vaccines $(36,96-98)$. Blocking antibodies against some of the signature costimulatory molecules expressed by Treg cells like CTLA-4 and GITR were able to induce potent antitumor immunity and this was associated with an increased number of tumorspecific interferon- $\gamma$-secreting $\mathrm{CD} 4^{+}$and $\mathrm{CD} 8^{+} \mathrm{T}$ cells in the spleen $(98,99)$. Strikingly, a combination of blocking antibodies against both CTLA-4 and GITR synergistically enhanced anti-tumor responses and was able to eradicate more advanced tumors in mice (98).

Interestingly, many tumors are known to produce cytokines such as IL-10 and TGF- $\beta$, which promote the proliferation of nTreg cells as well as the conversion of CD4 $\mathrm{T}$ cells into iTreg cells $(3,101,102)$. Conversion of naive $\mathrm{CD}^{+} \mathrm{T}$ cells into iTreg cells and their accumulation in tumor sites $(5,103)$ also play a key role in obstructing tumor immunosurveillance and cancer immunotherapies $(8,103)$. In one study, it has been reported that cyclooxygenase (COX)-2 and its product prostaglandin, play an important role in the pathogenesis of non-small cell lung cancer (104). COX-2 along 
with its product, prostaglandin, produced by tumors induced the expression of FoxP3 in $\mathrm{T}$ cells, and consequently increased Treg cell activity in the tumor (105). Furthermore, inhibition of COX-2 reduced Treg cell frequency and activity in the tumor and attenuated FoxP3 expression in tumor infiltrating lymphocytes along with decreased tumor burden.

Signaling through TNFR family members play an important role in the activation, proliferation, survival, and differentiation of both $\mathrm{CD}^{+}$and $\mathrm{CD}^{+}$Teff cells (181). Among the TNFR family members, 4-1BB has emerged as a key modulator of $\mathrm{CD}^{+}$and $\mathrm{CD}^{+} \mathrm{T}$ cell proliferation and survival. $4-1 \mathrm{BB}$ is not constitutively expressed on $\mathrm{T}$ cells, but rather induced upon $\mathrm{T}$ cell activation $(182,183)$. Signaling through $4-1 \mathrm{BB}$ also endows $\mathrm{T}$ effector cells to be refractory to suppression by Treg cells (Figure 2) $(12,14)$. 4-1BB ligation may exert multiple activities on both thymic (nTreg cells) and peripheral (iTreg cells) regulatory $\mathrm{T}$ cells at several stages. Ligation of 4-1BB promotes the proliferation and/or survival of already existing nTreg and iTreg cells, but inhibit the regulatory/suppressive function of these cells. However, 4-1BBL activity on the conversion of naïve $\mathrm{CD} 4^{+} \mathrm{T}$ cells to iTreg cells is not known.

We, therefore, hypothesized that 4-1BB signaling can be exploited for the development of therapeutic vaccines and generated a chimeric molecule, SA-4-1BBL, with core streptavidin (SA) where the extracellular domain of the mouse 4-1BBL was fused to C-terminus of SA. The SA portion of the molecule allows for oligomerization of the chimeric protein that possesses pleiotropic effects on cells of innate, adaptive, and regulatory immunity, which translate into therapeutic efficacy against cancer in various preclinical settings (184). Importantly, we had previously demonstrated that SA-4-1BBL costimulation makes Teff cells to be refractory to suppression by Treg cells and increases 
the ratio of $\mathrm{CD}^{+}$Teff to Treg cells at the tumor site when used as the adjuvant component of tumor associated antigen (TAA) based vaccines (184). Given the importance of iTreg cells in tumor immune evasion, we herein tested if SA-4-1BBL costimulation affects the conversion of Teff cells into iTreg cells. Our data demonstrate that SA-4-1BBL effectively inhibits antigen- and TGF- $\beta$-mediated conversion of Teff into Treg cells through induction of IFN- $\gamma$ produced in Teff cells. Importantly, immunomodulation with an SA-4-1BBL-based vaccine also blocks the conversion of Teff into iTreg cells in a tumor setting in vivo. Collectively, these data demonstrate the pleiotropic functions of SA-4-1BBL and its potential as an effective immunomodulator for the development of therapeutic vaccines against cancer and chronic infections.

\section{Materials and Methods}

\section{Mice and reagents}

OVA-specific TCR-transgenic C57BL/6 OT-II $\left(\mathrm{Rag}^{-1 /}\right)$ mice were purchased from Taconic Farms. C57BL/6.FoxP3.gfp and C57BL/6 mice were purchased from The Jackson Laboratory. OT-II.FoxP3.gfp mice were generated by crossing C57BL/6.FoxP3.gfp with OT-II $\left(\right.$ Rag $\left.^{-1 /}\right)$ mice. OT-II.FoxP3.gfp (CD45.1/2) mice were generated by crossing C57BL/6.FoxP3.gfp (CD45.2) with OT-II.SJL (CD45.1) mice.

C57BL/6 4-1BB ${ }^{-/}$mice were kindly provided by Dr. A.T. Vella of University of Connecticut, Farmington, CT, with permission from Dr. B.S. Kwon of University of Ulsan, Korea. OT-II 4-1BB ${ }^{-/}$mice were generated by crossing C57BL/6 4-1 $\mathrm{BB}^{-/-}$mice with OT-II $\left(\operatorname{Rag}^{-1 /}\right)$. Mice were maintained under specific pathogen-free conditions at the University of Louisville (Louisville, KY) and used at the age of 8-10 weeks. This study 
was reviewed and approved by the Institutional Animal Care and Use Committee of the University of Louisville, and animals were cared for in accordance to institutional and National Institutes of Health guidelines. OVA peptide (aa 323-339) was purchased from AnaSpec, Inc, Fremont, CA.

\section{$\mathrm{CD4}^{+} \mathrm{T}$ cell sorting}

Spleen and lymph nodes from OT-II $\left(\operatorname{Rag}^{-/}\right)$or OT-II $4-1 \mathrm{BB}^{-/-}$or OT-II.FoxP3.gfp mice were harvested and processed into single cell suspension, and RBCs were lysed using ACK solution. For sorting $\mathrm{CD}^{+} \mathrm{CD} 25^{-} \mathrm{T}$ cells from OT-II or OT-II 4-1BB ${ }^{-/-}$mice, cells were stained with CD25-PE and CD4-APC for 30 mins at $4^{\circ} \mathrm{C}$. Cells were washed and resuspended in HBSS media at a concentration of $5 \times 10^{6} / \mathrm{ml}$ in FACS tubes. For sorting $\mathrm{CD}^{+}$FoxP3.gfp ${ }^{-} \mathrm{T}$ cells from OT-II.FoxP3.gfp cells were stained with CD4-PE alone for 30 mins at $4^{0} \mathrm{C}$. Cells were washed and resuspended in HBSS media at a concentration of $5 \times 10^{6} / \mathrm{ml}$ in FACS tubes. Cells were sorted using a FACSVantage and FACSAria cell sorters (Figure 4) (BD Biosciences, San Jose, CA). In some experiments, sorted cells were labeled with $0.25 \mu \mathrm{M}$ CFSE before using them for in vitro cultures.

\section{Preparation of APCs}

For the preparation of APCs, spleen and lymph node cells from naïve C57BL/6 mice were depleted for $\mathrm{T}$ cells by first staining with anti $\alpha \beta-\mathrm{TCR}$ Ab (clone H57-597) for 30 mins. Cells were washed and incubated with Low-Tox-M rabbit complement (Cedarlane Laboratories, Burlington, $\mathrm{NC}$ ) for $60 \mathrm{~min}$ at $37^{\circ} \mathrm{C}$ for the lysis of $\mathrm{T}$ cells. After several washes with PBS, the live cells were irradiated with 2,000 cGy and used as APCs in 
coculture experiments with sorted OT-II CD $4^{+} \mathrm{CD} 25^{-} \mathrm{T}$ cells or OT-II CD4 ${ }^{+} \mathrm{FoxP} 3 . \mathrm{gfp}{ }^{-} \mathrm{T}$ cells. Cells were checked for $\mathrm{T}$ cell depletion using flow cytometry (Figure 4).

\section{In vitro $T$ cell cultures and phenotyping}

$5 \times 10^{5}$ cells $/ \mathrm{ml}$ of sorted naïve $\mathrm{CD}^{+} \mathrm{CD} 25^{-} \mathrm{T}$ cells from OT-Il or OT-II.4-1BB ${ }^{-/}$mice or $\mathrm{CD}^{+}{ }^{+}$FoxP3.gfp ${ }^{-} \mathrm{T}$ cells from OT-II.FoxP3.gfp mice were plated in 96 well plate with $2 \times 10^{6}$ cells $/ \mathrm{ml}$ of T cell depleted APCs from C57BL/6 to a final volume of $200 \mu 1$. Cells were cultured with varying doses of $(0.05-0.5 \mu \mathrm{M})$ OVA peptide $\left(\mathrm{OVA}_{323-339)}\right)$ and cultured in complete MLR media for 4 days.

Construction, expression, purification and characterization of SA-4-1BBL is previously described (185). To some cultures, SA-4-1BBL $(10 \mu \mathrm{g} / \mathrm{ml})$ or equimolar concentration of SA $(2.4 \mu \mathrm{g} / \mathrm{ml})$ as control and varying amounts $(0-2 \mathrm{ng} / \mathrm{ml})$ of recombinant human TGF- $\beta 1$ (PeproTech) were also added. Cultured cells were phenotyped using CD4 APC (Clone RM4-5) or CD4 PE (Clone GK1.5), CD25 PE or CD25 PE-Cy7 (Clone PC61). Intracellular FoxP3 staining was performed to cells that are not transgenic for EGFP according to the manufacturer's protocol (eBioscience, San Diego, CA). Isotype Abs with matched fluorochromes were used as controls. All samples were collected using FACSCalibur or BD LSR II (BD Biosciences) and analyzed using FlowJo (Tree Star) or FACS Diva software respectively.

For some in vitro experiements, culture supernatants were collected and analyzed for cytokines using a BD Cytometric Bead Array (CBA) Mouse Th1/Th2/Th17 Cytokine Kit (BDbiosciences) according to the manufacturer's protocol and analyzed using FCAP Array software (Soft Flow, Inc, St. Louis Park, MN). 


\section{In vivo Tumor experiment}

C57BL/6.SJL (CD45.1) mice were challenged s.c. in the right flank with $3 \times 10^{6}$ live OVA expressing EG.7 tumor cells. When the tumor size reached $9-10 \mathrm{~mm}$ in diameter, 3-4 $\times 10^{6}$ sorted $\mathrm{CD}^{+}$FoxP3.gfp - cells from OT-II.FoxP3.gfp (CD45.1/2) mice were adoptively transferred by intratumoral injection (Figure 8a). Mice were vaccinated one day later intratumorally with $25 \mu \mathrm{g}$ SA-4-1BBL or equimolar SA (control) protein. Spleen, draining and non-draining LNs, and tumor were harvested 5 days after vaccination and processed into single cell suspension as previously described (184). Cells were stained with CD45.1-PE, CD45.2-APC, CD4-Alexa 700 and CD25-PE-Cy7 and analyzed using flow cytometry.

\section{Confocal Microscopy for detection of intra-tumor iTreg cells}

Detection of FoxP3.gfp expressed by iTreg cells in the tumor using confocal microscopy requires unique tissue processing. During regular tissue processing for confocal microscopy, EGFP molecules lose their florescence ability in tissue sections or in cells that have lost membrane integrity (186). Therefore, fixation of tumor tissue is required before processing. Furthermore, these same fixation procedures must maintain the tissue structure so that the ability to detect other cell surface molecules by immunofluorescence. Briefly, for tumor confocal microscopy and efficient gfp (FoxP3) green florescence, each tumor were dissected into half and before any other procedures, tissues was fixed by immersion in $4 \%$ paraformaldehyde containing $10 \%$ sucrose for $24 \mathrm{hrs}$ at room temperature (RT) (186). Fixed tissue was embedded in OCT, and snap-frozen above liquid nitrogen. Frozen tissue blocks were stored at $-70^{\circ} \mathrm{C}$ and 5 micrometer sections 
were cut and placed on slides. Slides were dried at RT overnight, and then stained with DAPI antibody. Five-micrometer sections were stained with DAPI and analyzed for DAPI and gfp (FoxP3) using confocal microscopy.

\section{Statistical analysis}

Comparisons between two groups were performed using Student's $t$-test with Microsoft Excel software. For each test, $P$ values less than 0.05 considered significant. Data are represented as mean $\pm \mathrm{SD}$.

\section{Results}

\section{SA-4-1BBL inhibits antigenic conversion}

Naïve $\mathrm{CD} 4^{+} \mathrm{CD} 25^{-} \mathrm{T}$ cells have been shown to convert into iTreg cells under low dose of antigenic stimulation $(165,167)$. The first evidence of in vivo conversion by foreign antigens came from a study where mice treated with low doses of antigen cross-linked to DEC-205 $\mathrm{Ab}$ (targets antigens specifically to DCs) and delivered by osmotic pump. Conversion of $\mathrm{CD}^{+} \mathrm{CD} 25^{-} \mathrm{T}$ cells into iTreg cells was also shown in another adoptive transfer model where sorted CD4 cells were transferred into irradiated mice (72). Under these lymphophenic conditions, these cells readily underwent conversion and this was independent of thymus, but was dependent of CD28 signaling. Similarly, OVA-specific naïve $\mathrm{T}$ cells from $\mathrm{T} / \mathrm{B}$ monoclonal mice (17/9 DO11.10 $\mathrm{RAGl}^{-1-}$ ) converted into $\mathrm{FoxP}^{+}{ }^{+}$iTreg cells when mice were administered with chicken ovalbumin through oral route (83). Based on these studies, protocols have been developed for in vitro generation of iTreg cells using low doses of a given antigen (187). 
In vitro generation of iTreg cells requires both TCR stimulation and the cytokines TGF $-\beta$ is absolutely required for naïve $\mathrm{CD} 4^{+}$effector cells to convert into iTreg cells. During TCR-stimulation, addition of TGF- $\beta$ to naive $\mathrm{CD} 4^{+} \mathrm{T}$ cells cultures induces the expression of FoxP3 (66). Low dose antigenic conversion is known to depend on TGF- $\beta$ signaling and conditions that prevent activation of APCs as well as IL-2 production by naïve $\mathrm{T}$ cells (67). Conversion mediated by antigenic stimulation is dependent on the accumulation of AP-1 signaling molecule that can interact with TCR activated NFAT (188). Both AP-1 and FoxP3 are known to compete for NFAT binding. During subimmunogenic TCR stimulation, lesser availability of AP-1 is known to facilitate the binding of NFAT to FoxP3gene locus thereby promoting the expression of FoxP3 and generation of iTreg cells (189). Thus, TCR signaling is important in the generation of iTreg cells.

To investigate the effect of SA-4-1BBL on low dose antigen-driven conversion, we cultured naïve $\mathrm{CD} 4^{+} \mathrm{CD} 25^{-} \mathrm{T}$ cells transgenic for $\mathrm{OVA}_{323-339}$ with $\mathrm{T}$ cell-depleted $\mathrm{APCs}$ and varying doses of $\mathrm{OVA}_{323-339}$ peptide ranging from $0.05-0.5 \mu \mathrm{M}$ in the presence or absence of exogenous SA-4-1BBL (Figure 5a). After 4 days of culture, cultures were stained with CD4-APC, CD25-PE-Cy7 and FoxP3-PE, and analyzed using multiparameter flow cytometry by gating on $\mathrm{CD}^{+}$live $\mathrm{T}$ cells. There was an antigen dose-dependent increase in cell division as assessed by CFSE dilution (Figure 5a). Upregulated expression of both $\mathrm{CD} 25$ and FoxP3 was seen when sorted naïve $\mathrm{CD} 4{ }^{+} \mathrm{T}$ cells were cultured with lower rather than higher doses of antigen (Figure 5b, upper row). Importantly, costimulation mediated by SA-4-1BBL actively shifts the balance towards an effector phenotype which is evident by the decrease in FoxP3 ${ }^{+}$to FoxP3 ${ }^{-}$ratio (Figure 
$5 b$, bottom row). Addition of SA control protein did not affect the rate of conversion and were comparable to cultures which only received different doses of antigen (Figure 5b, middle row). SA-4-1BBL costimulation also significantly inhibited the absolute number of $\mathrm{CD}^{+} \mathrm{FoxP}$.gfp ${ }^{+} \mathrm{T}$ cells generated as compared with untreated controls at any given dose of antigen (Figure 5d).

To further test whether this inhibition of conversion is exclusively mediated by signaling through 4-1BB ligand, we cultured naïve $\mathrm{CD} 4^{+} \mathrm{CD} 25^{-} \mathrm{T}$ cells from OT-II 4$1 \mathrm{BB}^{-/-}$mice with lowest dose of antigen where the conversion rate was higher. This effect was SA-4-1BBL specific and required 4-1BB signaling since 4-1BB KO cells treated with SA-4-1BBL had similar levels of FoxP3 ${ }^{+} \mathrm{T}$ cells as compared with untreated control cells (Figure. 5c). Collectively, these data demonstrate that costimulation mediated by SA-4-1BBL antagonizes the low dose antigenic stimulus required for the conversion of naïve $\mathrm{CD} 4^{+} \mathrm{T}$ cells into iTreg cells.

\section{SA-4-1BBL inhibits TGF- $\beta$ mediated conversion}

TGF- $\beta$ along with TCR stimulation converts peripheral $\mathrm{CD} 4{ }^{+} \mathrm{CD} 25^{-}$naive $\mathrm{T}$ cells to iTreg cells by induction of transcription factor FoxP3 $(69,166,167)$. TGF- $\beta$ induces FoxP3 expression through the activation of the transcription factor SMAD3 which in combination with TCR induced NFAT binds to the enhancer region of FoxP3 ultimately resulting in its transcription (132). The findings that 4-1BB stimulation under low dose of antigen appeared to inhibit the conversion of CD4 T cells into FoxP3 expressing Treg cells prompted us to further investigate the activity of 4-1BB signaling on TGF- $\beta$ mediated iTreg generation. To this purpose we used a higher dose of antigen where we 
do not see the effect of antigen driven conversion (Figure 5a). Stimulating naïve $\mathrm{CD} 4^{+}$ FoxP3.gfp ${ }^{-} \mathrm{T}$ cells at higher dose of antigen $(0.5 \mu \mathrm{M})$ in the presence of exogenous TGF- $\beta$ resulted in FoxP3 ${ }^{+}$iTreg cells in a dose dependent manner (Figure 6a, upper row). A blocking $A b$ to TGF- $\beta$ totally blocked the generation of iTreg cells, demonstrating the specificity of TGF- $\beta$-mediated conversion (Figure $6 \mathrm{~b}$ ). Consistent with the low-dose antigenic stimulation, SA-4-1BBL costimulation significantly inhibited the TGF- $\beta$ mediated conversion as assessed by percent as well as absolute number of $\mathrm{CD}^{+}$ FoxP3.gfp ${ }^{+} \mathrm{T}$ cells generated as compared with SA treated or untreated controls (Figure 6a, b). Collectively, these results demonstrate that signaling through 4-1BB on activated T cells can suppress the expression of FoxP3 in the presence of exogenous TGF- $\beta$.

\section{Cytokine milieu established by 4-1BB signaling control the conversion}

It has been demonstrated by various studies that signaling through OX40, another TNFR family costimulatory member, results in the inhibition of both low dose antigen as well as TGF- $\beta$ mediated conversion of naïve $\mathrm{CD} 4^{+} \mathrm{CD} 25^{-} \mathrm{T}$ cells into iTreg cells $(190,191)$. One study showed that signaling through OX40 induces memory T cells and IFN- $\gamma$ produced by these memory $\mathrm{T}$ cells inhibit TGF- $\beta$ mediated conversion of naïve $\mathrm{CD} 4{ }^{+} \mathrm{T}$ cells into iTreg cell (192). In a different model, another study has shown that OX40 induced IFN$\gamma$, IL-6 and IL-4 block the generation of iTreg cells from naïve $\mathrm{CD}^{+}{ }^{+} \mathrm{T}$ cells

During $\mathrm{T}$ cell activation signaling through $4-1 \mathrm{BB}$ is shown to promote the secretion of differentiating cytokines such as IFN- $\gamma$ and IL-4 (181), but the role of these cytokines in the generation of iTreg cells is not clear. We analyzed the culture supernatants for various $\mathrm{Th} 1 / \mathrm{Th} 2 / \mathrm{Th} 17$ cytokines using cytometric bead array. It 
revealed that 4-1BB stimulation significantly increased the production of IFN- $\gamma$ but not IL-4, IL-6 and IL-17 (Figure 7a). To determine to what extent these cytokines play a role in SA-4-1BBL mediated inhibition of Treg conversion, blocking Abs against IFN- $\gamma$ and IL-4 at varying doses were added to the cultures containing TGF- $\beta$ and SA-4-1BBL. Addition of $5 \mu \mathrm{g} / \mathrm{ml}$ of $\alpha-\mathrm{IFN}-\gamma$ Ab to cultures stimulated with SA-4-1BBL partially rescued the conversion of naïve CD4 T cells into Treg cells mediated by TGF- $\beta$ (Figure $7 \mathrm{~b})$. Importantly, addition of $25 \mu \mathrm{g} / \mathrm{ml} \alpha-\mathrm{IFN}-\gamma \mathrm{Ab}$ to the cultures significantly increased the frequency of FoxP $3^{+} \mathrm{T}$ cells completely abolishing the effect of 4-1BBL as shown by the percentage as well as the absolute number of $\mathrm{CD}^{+} \mathrm{FoxP} \cdot \mathrm{gfp}^{+} \mathrm{T}$ cells (Figure $7 \mathrm{~b}, \mathrm{c}$ ). We could not totally rescue the absolute number of $\mathrm{CD}^{+} \mathrm{FoxP} 3 \cdot \mathrm{gfp}^{+} \mathrm{T}$ cells by adding $25 \mu \mathrm{g} / \mathrm{ml} \alpha-\mathrm{IFN}-\gamma \mathrm{Ab}$ as compared to TGF- $\beta$ alone (Figure $7 \mathrm{c}$ ), which might be due to secondary effects of blocking $\alpha$-IFN- $\gamma$ Ab. We saw a decreased live cells (data not shown) when we added antibodies to the cultures. Due to this decreased live cells in the cultures, we compared the ratios of Teff cells versus iTreg cells and found that SA-41BBL decreased the absolute number of $\mathrm{CD}^{+}{ }^{+} \mathrm{FoxP}^{+}$cells as compared to $\mathrm{CD}^{+}{ }^{+} \mathrm{FoxP} 3^{-}$ cells and this effect was reverted when we added $25 \mu \mathrm{g}$ of IFN- $\gamma$ to the cultures (Figure 7d). Consistent with our cytokine quantitative data (Figure 7a), addition of $\alpha-\mathrm{IL}-4 \mathrm{Ab}$ to cultures stimulated with SA-4-1BBL had no effect on the conversion of naïve CD4 T cells into Treg cells (Figure $7 \mathrm{~b}, \mathrm{c}$ ). Collectively, these results indicate that IFN- $\gamma$ stimulated by $4-1 \mathrm{BB}$ signaling play a major role in inhibiting TGF- $\beta$ mediated Treg conversion.

\section{SA-4-1BBL inhibits tumor mediated conversion}

Treg cells, both naturally occurring and induced, play a dominant role in tumor immune 
evasion mechanisms as demonstrated by a series of clinic (193) and preclinical studies $(164,168,194)$. Importantly, most tumors express high levels of TGF- $\beta$, and as such can actively convert tumor-specific $\mathrm{T}$ effector cells into iTreg cells as an effective means of immune evasion (195). We, therefore, tested if the observed immunomodulatory effect of SA-4-1BBL on iTreg conversion can be translated in vivo in the OVA expressing EG.7 tumor model (Figure 8a). In this context, we first determined whether established EG.7 OVA tumors can convert adoptively transferred naïve $\mathrm{CD} 4^{+}$FoxP3.gfp ${ }^{-}$cells from OTII.FoxP3.gfp mice into $\mathrm{CD}^{+}{ }^{+}$FoxP3.gfp ${ }^{+}$cells. As expected, control SA injected mice converted $\mathrm{CD}^{+}{ }^{+}$FoxP3.gfp ${ }^{-}$cells into $\mathrm{CD}^{+} \mathrm{FoxP}_{3} \mathrm{gfp}^{+}$cells significantly in spleen (Figure $8 \mathrm{~b}$ ) and to a lesser extent in the draining LN (dLN) (Figure 8c). Similar to the in vitro data, mice vaccinated with SA-4-1BBL readily blocked the tumor mediated conversion as evident by the decrease in the percentage of $\mathrm{CD}^{+} \mathrm{FoxP} 3 . \mathrm{gfp}^{+}$cells in spleen and dLN (Figure 8b, c). Although, we observed high levels of iTreg cells in tumor draining LNs as compared with SA-treated controls, this difference did not reach statistical significance. This effect was also seen within the tumor microenvironment as significantly lower number of FoxP3.gfp ${ }^{+}$cells were evident in tumors of mice vaccinated with SA-4-1BBL as compared to SA control tumors (Figure 9a, b). Confocal microscopy further showed that SA-4-1BBL blocks the accumulation of FoxP3.gfp ${ }^{+} \mathrm{T}$ cells in the tumor as compared to SA control tumors. Taken together, these results demonstrate that immunomodulation with SA-4-1BBL is effective in preventing the conversion of $\mathrm{CD}^{+}$FoxP3.gfp ${ }^{-} \mathrm{T}$ effector cells into $\mathrm{CD}^{+}{ }^{\mathrm{F}}$ FoxP3.gfp ${ }^{+}$iTreg cells in a tumor microenvironment. These results are consistent with and provide a plausible mechanistic insight into our recently published studies demonstrating that vaccination with SA-41BBL and HPV E7 TAA showed potent therapeutic efficacy established TC-1 tumors 
that was associated with the production of high levels of IFN- $\gamma$ and a higher intratumoral $\mathrm{CD}^{+}$Teff/Treg ratio (196).

\section{$\underline{\text { Discussion }}$}

Signaling through 4-1BB receptor plays a critical role in modulating not only adaptive, but also innate and regulatory immunity as demonstrated by us $(184,185)$ and others (197-200), and as such may have important therapeutic implications in settings of autoimmunity, cancer, and chronic infections. In the context of regulatory immunity, signaling via 4-1BB receptor may have diverse and opposing consequences. For example, we $(185)$ and others $(199,200)$ have previously demonstrated that signaling via 4-1BB on naturally occurring Treg cells serves to expand them in vitro in the presence of exogenous IL-2. However, Treg cells have no suppressive function in the presence of the ligand since signaling via 4-1BB on $\mathrm{T}$ effector cells endows these cells to be refractory to inhibition by Treg cells (185) via yet to be defined mechanisms. Although, the physiological consequence of the expansion of nTreg cells via 4-1BB signaling during the course of an immune response is not obvious, it may serve as an alternative mechanism to activation induced cell death for achieving immune homeostasis after an antigenic challenge and/or preventing extensive collateral damage by controlling the function of expanded Teff cells. This outcome may be regulated by transient interaction between 4-1BBL inducible expressed on APCs with 4-1BB on Treg and Teff cells. The present study reveals another important and novel function of 4-1BB signaling on regulating the balance between adaptive and regulatory immunity, i.e., blocking the de novo generation of iTreg cells from Teff cells through IFN- $\gamma$ production. Therefore, the triple function of 4-1BB signaling on $\mathrm{T}$ cells to i) enhance activation of naïve $\mathrm{T}$ cells, 
survival, and differentiation into long-term memory with a Th1 response (184) ii) endow Teff cells to be refractory to inhibition by Treg cells (185), and iii) inhibit the conversion of Teff cells to iTreg cells, reported in the present study, may have important implications for the treatment of cancer that exploits Treg cells for immune evasion $(164,170)$ and requires a Th1 dominated response for immunotherapy (196). These features are not unique to 4-1BB as OX-40, another member of the TNFR superfamily, has similar effects in regulating the balance between Teff and Treg cells with the exception that it directly blocks the inhibitory function of Treg cells via the down regulation of FoxP3 expression (201, 202). Similar to our finding with 4-1BB, OX-40 also utilizes IFN- $\gamma$ to block the conversion of Teff cells into iTreg cells $(190,191,203)$ even though there are reports that OX-40 induced IL-4 and IFN- $\gamma$ (190) or in combination with IL-6 (203) are required for this function. The likely cause for such a discrepancy can be attributed to different culture systems used. Given the preferential effect of signaling via OX-40 on $\mathrm{CD} 4^{+}$and 4-1BB on $\mathrm{CD}^{+} \mathrm{T}$ cell function (204) and the importance of both of these cell types for the generation of effective immune responses, a combinatorial use of agonists for these two receptors for immunomodulation bears significant therapeutic potential for cancer and chronic infections.

4-1BB signaling is known to promote cell division, survival, and cytokine production. The downstream molecules and their transcribed products that are upregulated by 4-1BB signaling might negatively regulate transcription of FoxP3 that is mediated by TGF- $\beta$ signaling. Current study indicate that cytokines such as IFN- $\gamma$ produced from 4-1BB signaling may be important for suppressing FoxP3 expression, essentially providing a mechanism for suppressing iTreg cell generation. The source of 
IFN- $\gamma$ produced in these cultures is mainly from sorted naive $\mathrm{CD}^{+}$cells stimulated with antigen, but not from APCs as we did not detect any IFN- $\gamma$ in the culture supernatants containing APCs alone (data not shown). This suggests that increased IFN- $\gamma$ produced by SA-4-1BBL stimulated $\mathrm{CD} 4^{+}$cells acts in an autocrine fashion serving as an inhibitor of FoxP3 expression.

It is presently unknown how IFN- $\gamma$ produced by $4-1 \mathrm{BB}$ signaling might interfere with the induction of FoxP3 in antigen-stimulated naïve $\mathrm{T}$ cells. IFN- $\gamma$ might act either directly or indirectly on multiple signaling pathways that are required for the FoxP3 expression. First, naïve CD4 T cells give rise to Th1, Th2, Th17, and iTreg populations, mainly promoted in a cytokine-dependent manner which in turn regulates various lineage-specific transcription factors like T-bet, GATA-3, ROR $\gamma$ t, and FoxP3, respectively (205). Interestingly, recent data found that $\mathrm{Th} 1$ and $\mathrm{Th} 2$ lineage-specific cytokines like IFN- $\gamma$, IL-12 and IL-4 and the transcription factors they upregulate (T-bet by IFN- $\gamma$ and IL-12; GATA-3 by IL-4), act as strong suppressors of FoxP3 expression (206). Thus, it is possible that IFN- $\gamma$ induced by 4-1BB signaling might indirectly promote to upregulation of T-bet. T-bet may in turn suppress TGF- $\beta$ mediated transcription of FoxP3. Second, prolonged TGF- $\beta$ receptor signaling is necessary to maintain intracellular FoxP3 $(79,207)$, which might be due to the requirement for DNA demethylation and epigenetic modification at the FoxP3 promoter site. This suggests that upstream or downstream signals from the TGF- $\beta$ signaling like SMAD3, might be the primary targets of suppression by IFN- $\gamma$ signaling pathway. Third, it has been recently shown that TGF- $\beta$ signaling was found to promote upstream demethylation of the FoxP3 gene, thereby enhancing FoxP3 expression. Even though the exact mechanism of this process is unknown, it is speculated that this might be mediated by TGF- $\beta$ 
signaling mediated suppression of a DNA methyltransferase (208). Inhibiting the TGF- $\beta$ mediated suppression of DNA methyltransferase might also serve as an alternate target for INF- $\gamma$ antagonism on FoxP3 expression.

In conclusion, previous studies have shown that signaling via 4-1BB on nTreg cells can expand them in vitro $(12,162,209)$ as well as endows Teff cells to be refractory to inhibition by Treg cells (185). In the current study, we have shown that 4-1BB signaling also inhibit the conversion of Teff cells to iTreg cells through the production of INF- $\gamma$. Although, the physiological consequence of these contradicting functions of 41BB signaling during the course of an immune response is not obvious, it may serve in achieving immune homeostasis. 4-1BB signaling on Teff cells might help in mounting an effective immune response to pathogens while simultaneously expanding Treg cells. Once pathogen is cleared, the expanded Treg cells can then regulate the function of Teff cells to control extensive collateral damage. 


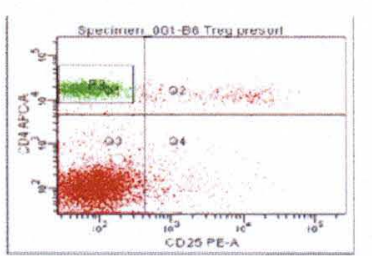

$0.5 \times 10^{6}$ sorted $\mathrm{CD}^{+} \mathrm{CD} 25^{-}$from OT-II or CD4 ${ }^{+}$FoxP3.gfp- cells from OT-II.FoxP3.gfp mice

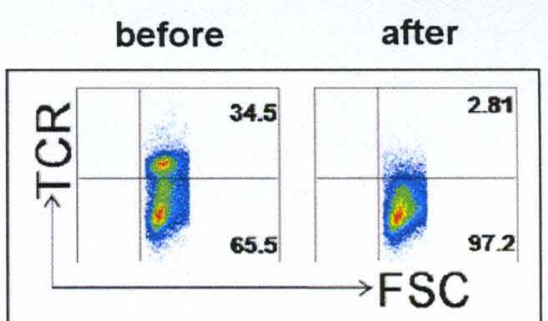

$2 \times 10^{6} \mathrm{~T}$ cell depleted cells (APCs) from C57BL/6
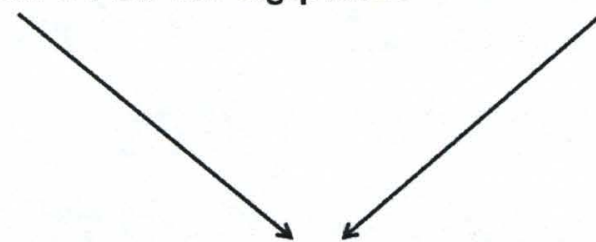

Culture for 4 days with $\mathrm{OVA}_{323-339}, \mathrm{SA}-4-1 \mathrm{BBL}(10 \mu \mathrm{g} / \mathrm{ml})$

Flow cytometric analysis for CD4, CD25 and FoxP3

Figure 4. Outline of in vitro conversion of naïve $\mathrm{CD}^{+} \mathrm{T}$ cells into FoxP3 ${ }^{+} \mathrm{T}$ cells. Briefly, sorted $\mathrm{CD} 4^{+} \mathrm{CD} 25^{-}$or $\mathrm{CD} 4^{+}$FoxP3.gfp ${ }^{-}$cells were cultured with $\mathrm{T}$ cell depleted APCs in the presence of OVA323-339 peptide $(0.05$ to $0.75 \mu \mathrm{M})$, TGF- $\beta(0.1$ to $2 \mathrm{ng} / \mathrm{ml})$, SA-4-1BBL and SA as control. Cells were analyzed after 4 days of culture using flow cytometry. 
A.

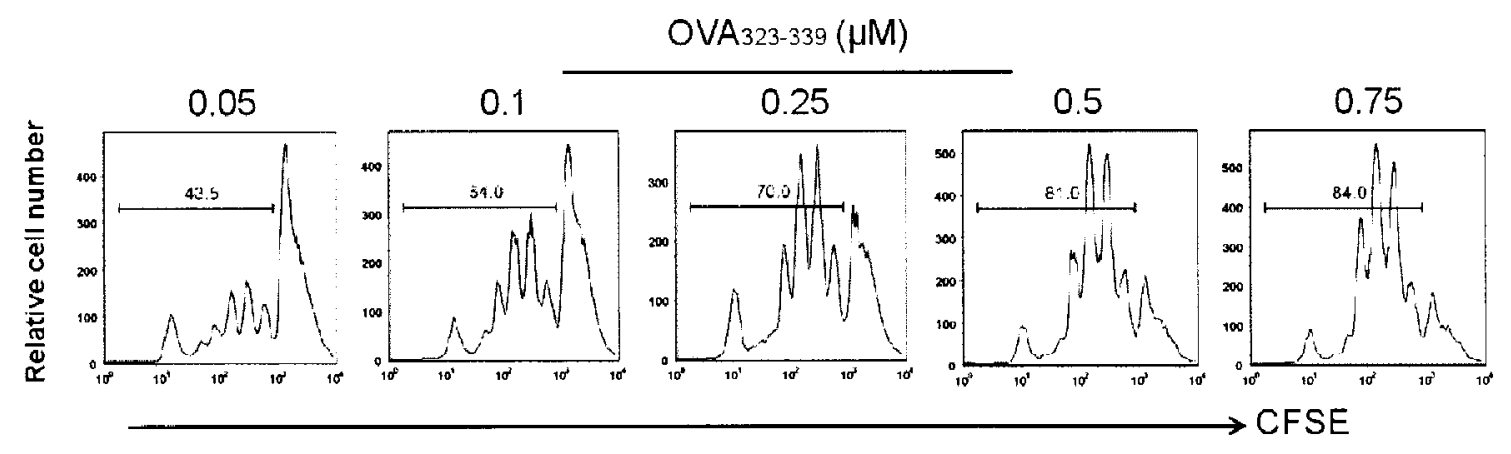

B.

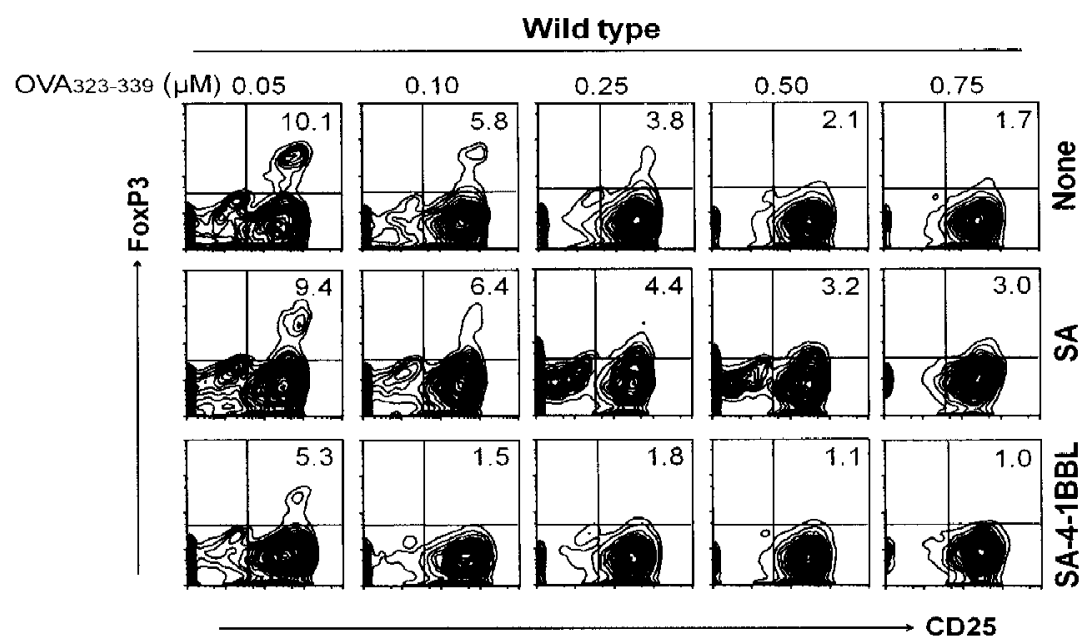

C.

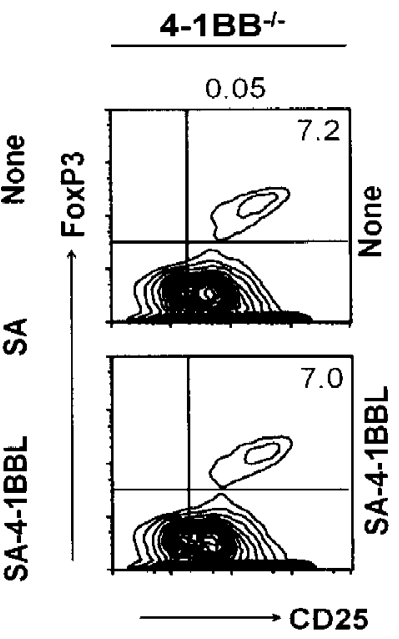

D.

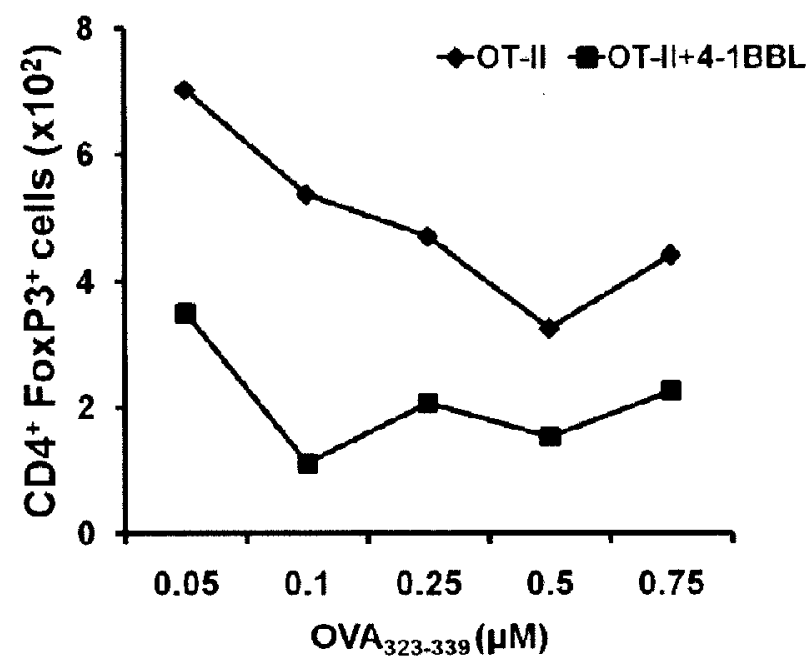


Figure 5. 4-1BBL inhibits the conversion of naïve $\mathrm{CD} 4 \mathrm{~T}$ cells into $\mathrm{CD} 25^{+} \mathrm{FoxP} 3^{+} \mathrm{T}$ cells. A, In vitro $\mathrm{CD}^{+} \mathrm{T}$ cell $\mathrm{CFSE}$ cell division. Flow sorted $\mathrm{CD}^{+} \mathrm{T}$ cells were stimulated for 4 days with various doses of $\mathrm{OVA}_{323-339}$ peptide in the presence of irradiated C57BL/6 T cell depleted APCs. CFSE dilution was analyzed using flow cytometry by gating on $\mathrm{CD} 4^{+}$cells. $\mathrm{B}$, naïve $\mathrm{CD} 4^{+} \mathrm{CD} 25^{-} \mathrm{T}$ cells from wild type OT-II transgenic mice were cultured with APCs (T cell depleted) and with various doses of OVA $_{323-339}$ peptide (upper row) in the presence of SA- 4-1BBL (bottom row) and equimolar SA (middle row) as control. After 4 days, CD25 and intracellular FoxP3 were evaluated by gating on $\mathrm{CD}^{+} \mathrm{T}$ cell population using flow cytometry. Data is representative of at least three independent experiments. $\mathrm{C}$, as in $\mathrm{B}$, naïve $\mathrm{CD} 4^{+} \mathrm{CD} 25^{-}$ $\mathrm{T}$ cells from $4-1 \mathrm{BB}^{-/}$OT-II transgenic mice were cultured with $0.05 \mu \mathrm{M}$ of $\mathrm{OVA}_{323-339}$ peptide with (bottom row) or without (upper row) SA- 4-1BBL and FoxP3 and CD25 expression was accessed by gating on $\mathrm{CD}^{+} \mathrm{T}$ cells. $\mathrm{D}$, Absolute number of $\mathrm{CD} 4^{+} \mathrm{FoxP} 3^{+}$ $\mathrm{T}$ cells generated from cultures as in $\mathrm{B}$. Data is representative of at least three independent experiments with similar results. 
A.

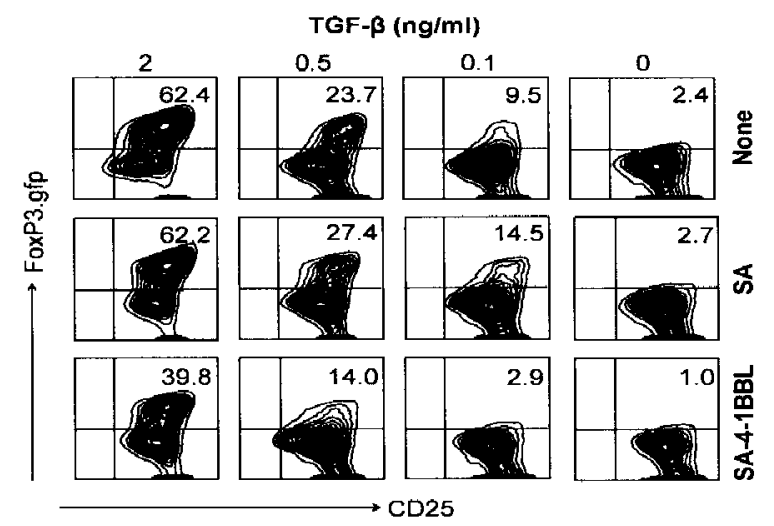

B.

C.

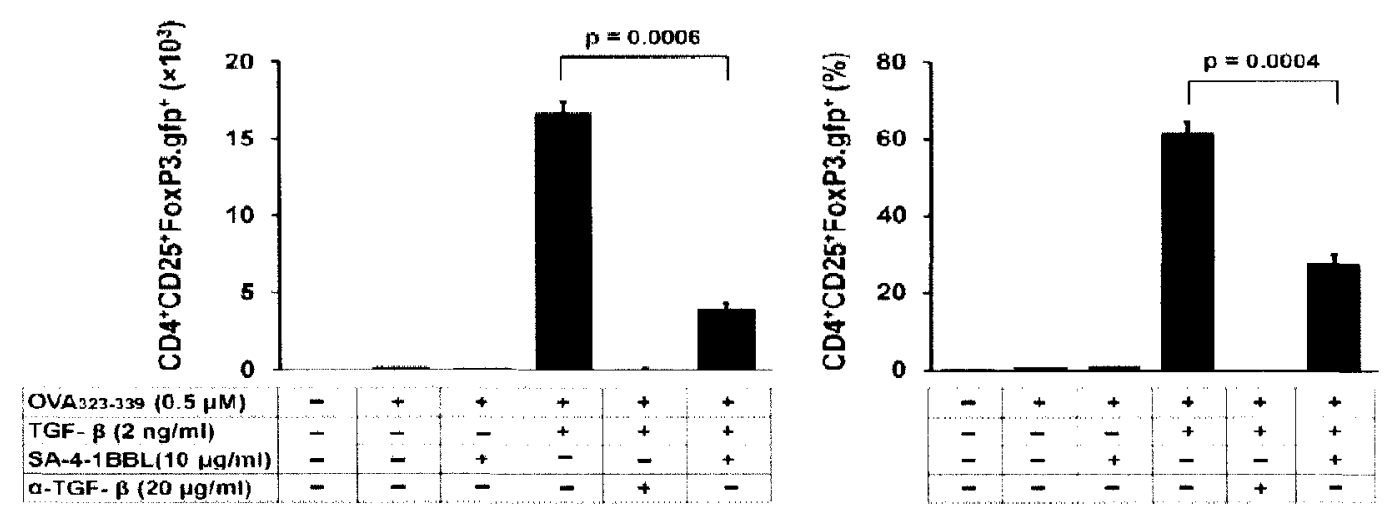

Figure 6. 4-1BBL suppresses expression of FoxP3 induced by exogenous TGF- $\beta$. A, naïve $\mathrm{CD}^{+}$FoxP3.gfp ${ }^{-} \mathrm{T}$ cells from OT-II.FoxP3.gfp mice were cultured with $\mathrm{T}$ cell depleted APCs and $0.5 \mu \mathrm{M}_{\text {OVA }} 323-339$ with different doses of exogenous TGF- $\beta$ in the presence (lower row) or absence (upper row) of SA-4-1BBL or with equimolar concentration of SA (middle row) as control. At day 4, CD25 and EGFP (FoxP3) expression in $\mathrm{CD}^{+} \mathrm{T}$ cells was analyzed using flow cytometry. Data is representative of at least three experiments. B, C, as in A were cultured and analyzed after 4 days of stimulation for total number (B) or percentage (C) of live $\mathrm{CD} 4^{+}$FoxP3.gfp ${ }^{+}$cells generated. $\alpha$-TGF- $\beta$ neutralizing antibody was used as control. Data are mean \pm SD and are representative of at least three independent experiments with similar results. 
A.

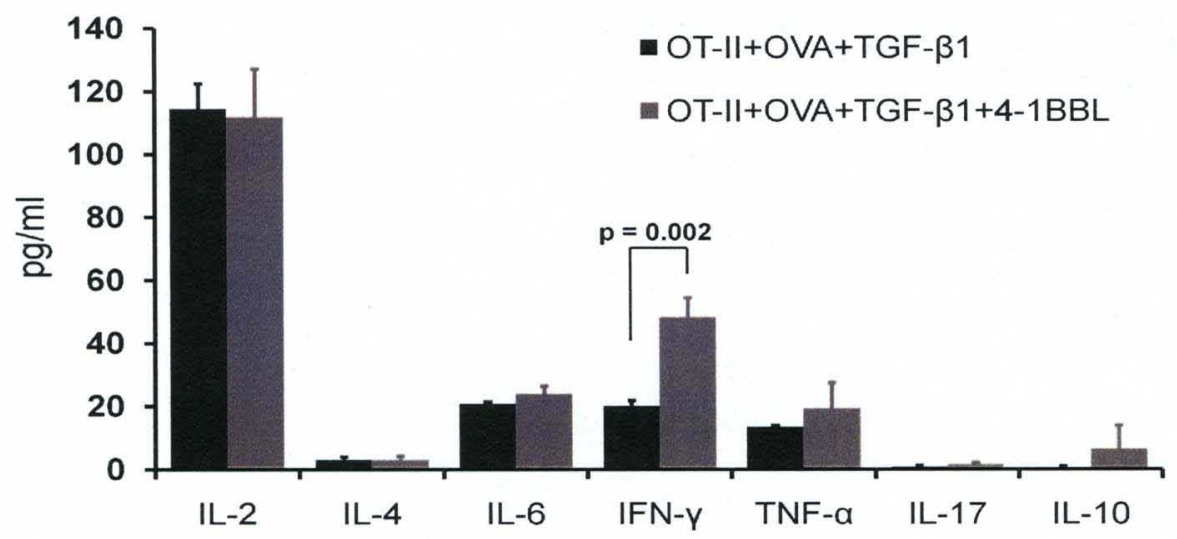

B.

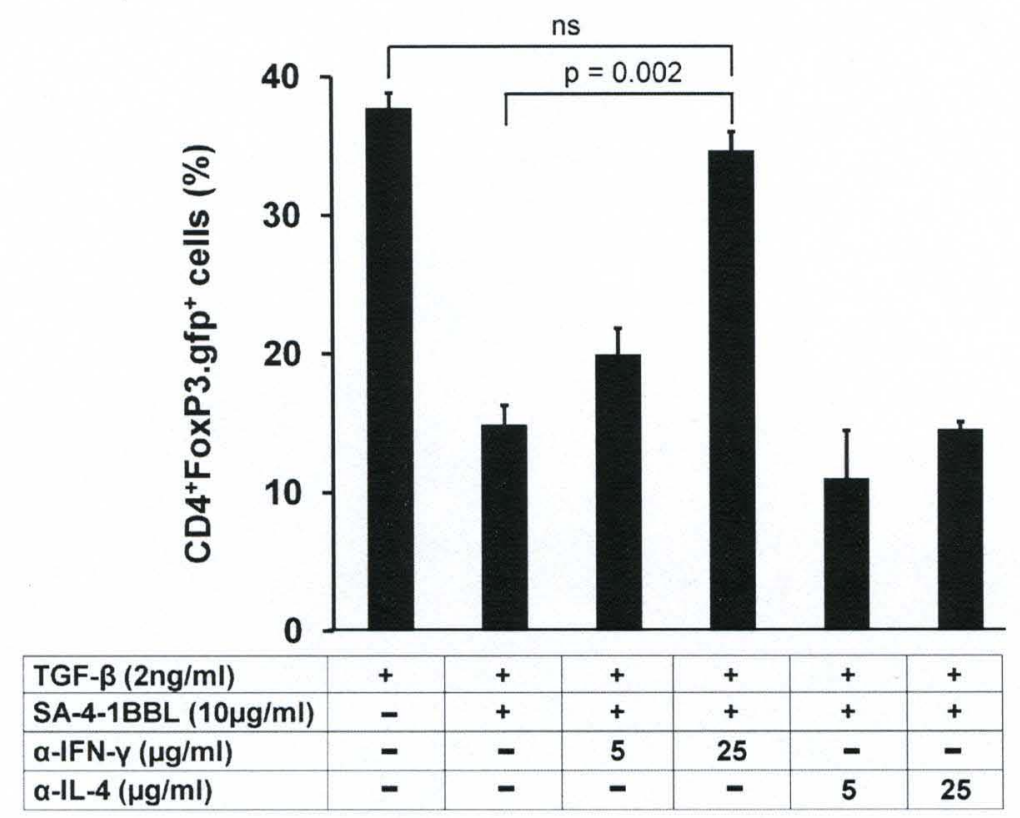


C.

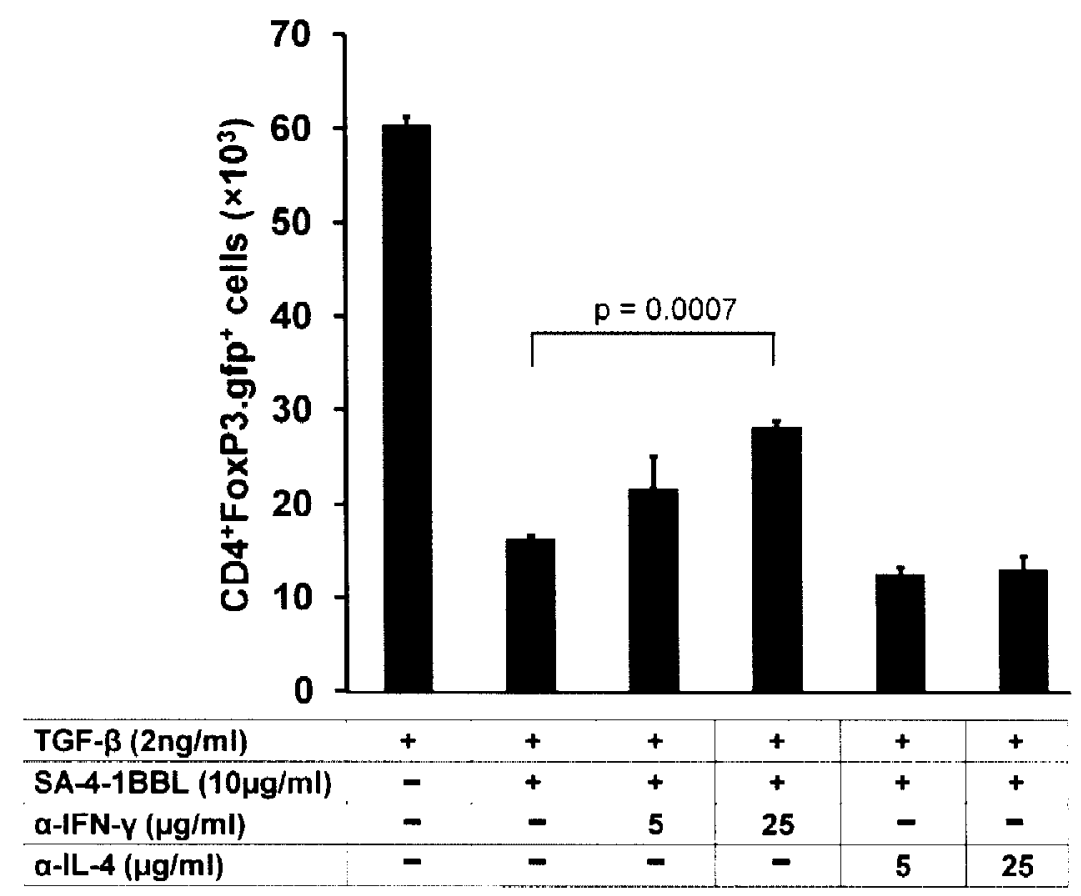

D.

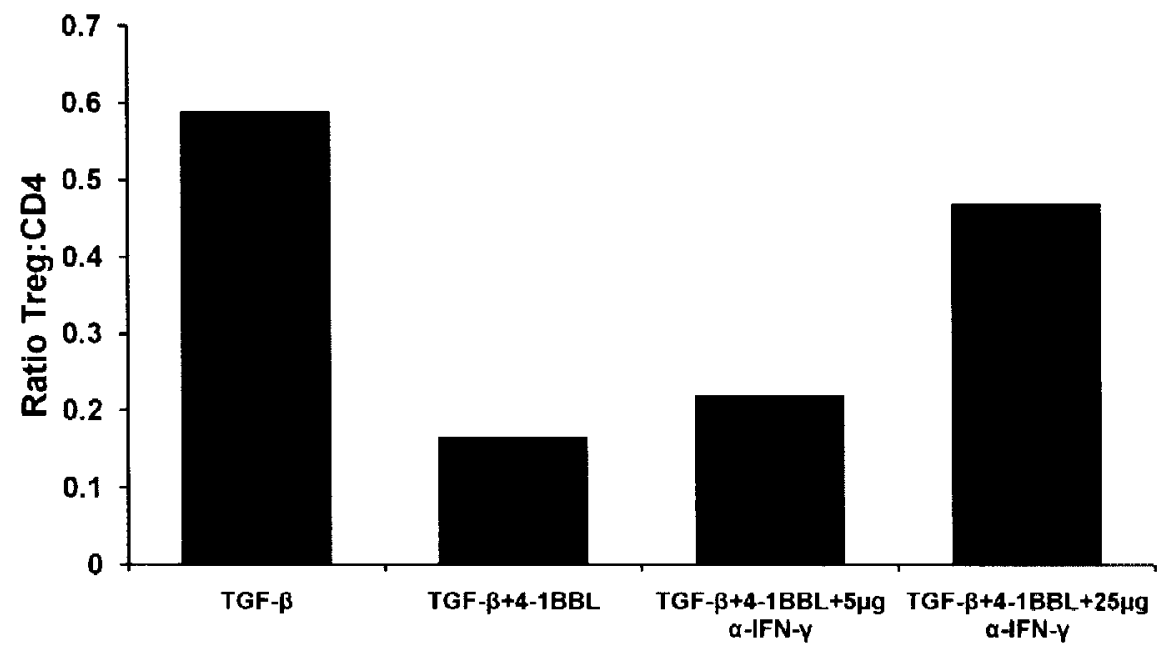

Figure 7. 4-1BBL suppression of FoxP3 induction is mediated by IFN- $\gamma$. A, naïve $\mathrm{CD}^{+}$FoxP3.gfp ${ }^{-} \mathrm{T}$ cells from OT-II.FoxP3.gfp mice were cultured with $\mathrm{T}$ cell depleted APCs and $0.5 \mu \mathrm{M} \mathrm{OVA}_{323-339}$ with exogenous TGF- $\beta(2 \mathrm{ng} / \mathrm{ml})$ with or without $4-1 \mathrm{BBL}$ 
$(10 \mu \mathrm{g} / \mathrm{ml})$ and 4 days later, culture supernatants were analyzed for levels of various cytokines. $\mathrm{B}$, as in $\mathrm{A}$, naïve $\mathrm{CD}^{+} \mathrm{FoxP} 3$.gfp ${ }^{-} \mathrm{T}$ cells from OT-II.FoxP3.gfp mice were cultured in the presence or absence of varying doses of IFN- $\gamma$ or IL-4 blocking antibodies. At day 4, CD25 and EGFP (FoxP3) expression in CD4 T cells was analyzed using flow cytometry. C, absolute number of $\mathrm{CD}^{+}{ }^{+}$FoxP3.gfp ${ }^{+} \mathrm{T}$ cells from $\mathrm{B}$. D, ratio of the absolute number of $\mathrm{CD} 4^{+} \mathrm{FoxP} 3 . \mathrm{gfp}^{-}$cells versus $\mathrm{CD} 4^{+} \mathrm{FoxP} 3 . \mathrm{gfp}^{+}$from the cultures as in $\mathrm{B}$. 
A.
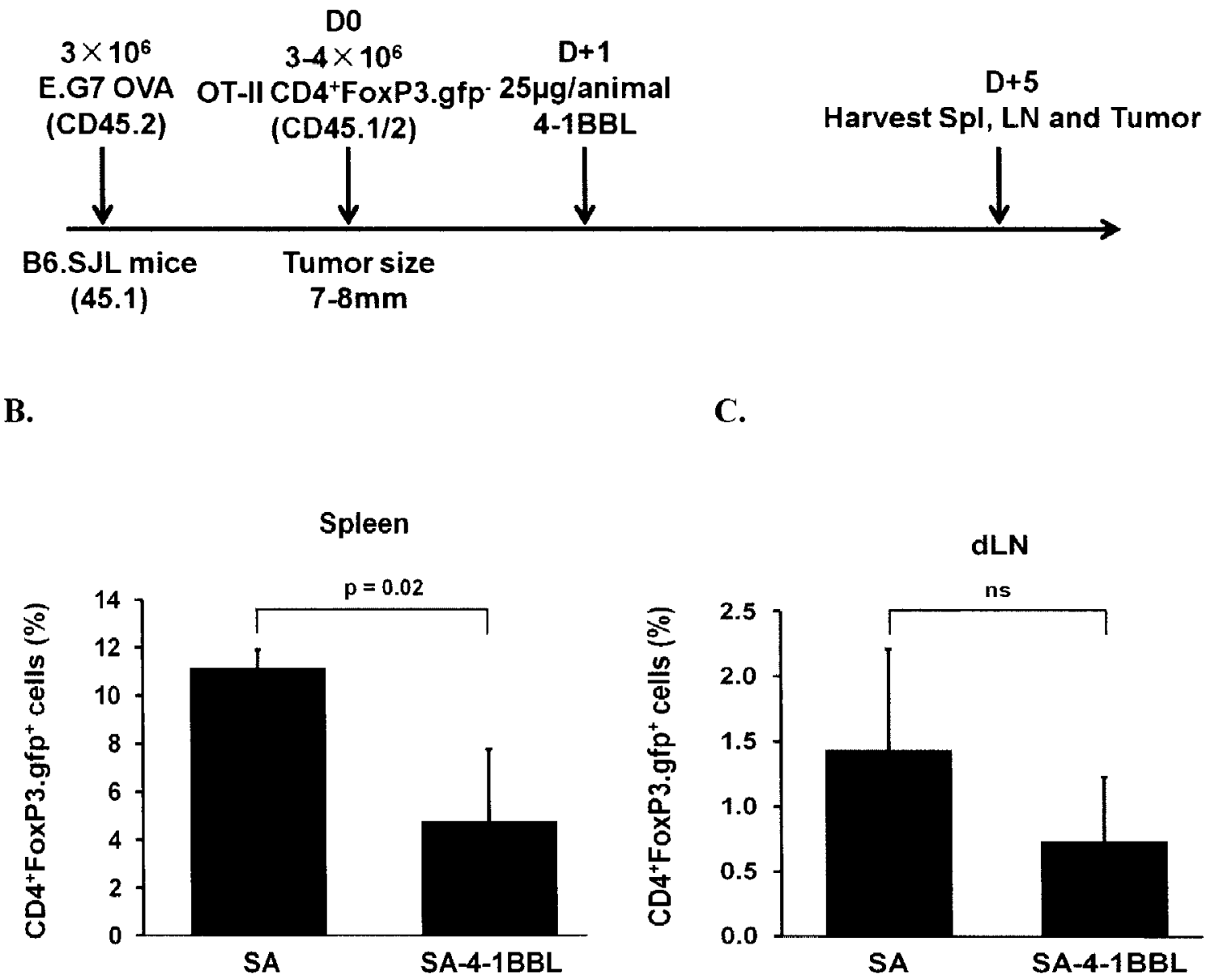

Figure 8. SA-4-1BBL blocks the accumulation of CD $4^{+}$FoxP3.gfp ${ }^{+} \mathrm{T}$ cells in spleen and dLN. A. Schematic diagram of in vivo tumor experiment. B, C, sorted naïve $\mathrm{CD}^{+}$FoxP3.gfp ${ }^{-} \mathrm{T}$ cells $\left(\mathrm{CD} 45.1 / 2^{+} ; 4 \times 10^{6}\right)$ were injected intratumorally into tumor bearing C57BL/6.SJL (CD45. $1^{+}$) mice. On the next day, mice were vaccinated intratumorally with SA-4-1BBL $(25 \mu \mathrm{g})$ or equimolar SA control protein. Transferred cells were assessed from spleen (B) and draining LNs (C) $5 \mathrm{~d}$ after vaccination by gating on $\mathrm{CD}^{+} \mathrm{CD} 45.1 / 2^{+}$cells using flow cytometry. Data are mean $\pm \mathrm{SD}$ and are representative of two independent experiments with at least 3 animals per group. 
A.
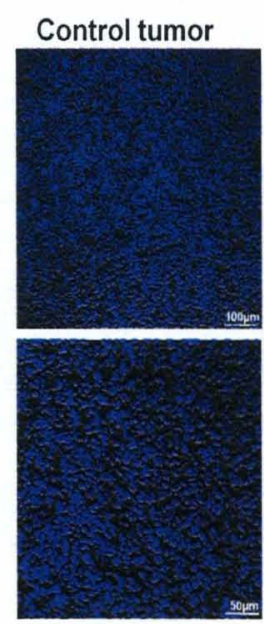

SA
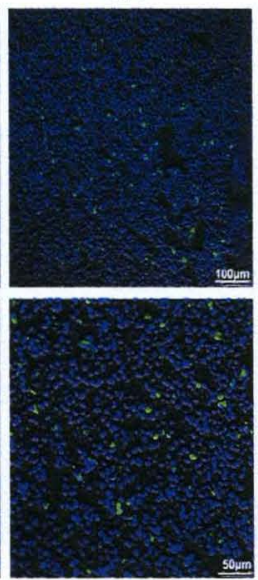

SA-4-1BBL
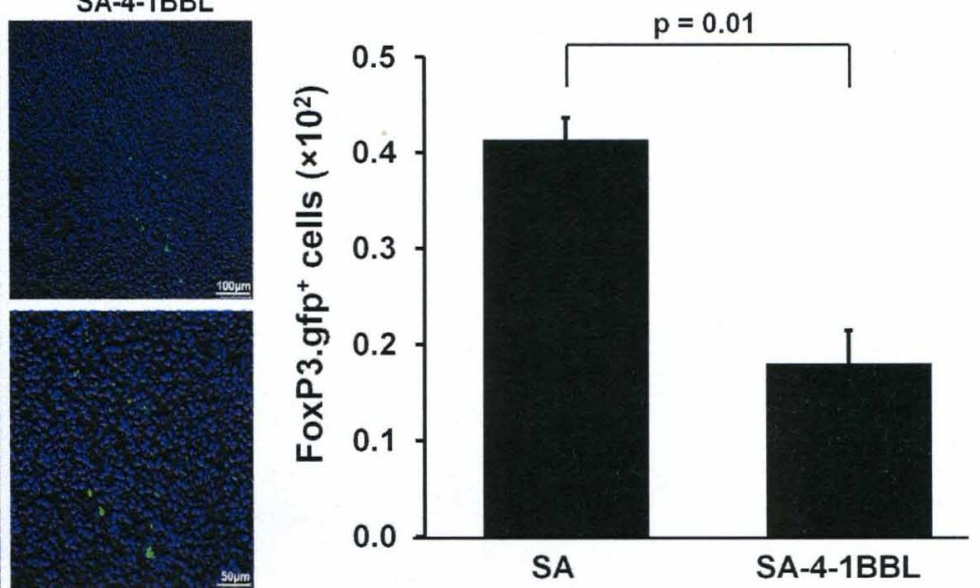

Figure 9. SA-4-1BBL blocks the accumulation of $\mathrm{CD}^{+}{ }^{+}$FoxP3.gfp ${ }^{+} \mathrm{T}$ cells within the tumor. A, confocal microscopic images of tumor tissue showing intracellular gfp (FoxP3, green) and DAPI (blue). B, absolute number of cells from more than three areas per donor sample from three independent donor samples per group counted from the confocal images. Control tumors did not receive $\mathrm{CD}^{+}{ }^{+}$FoxP3.gfp ${ }^{-}$cells and served as a background for gfp (FoxP3) staining. 


\section{CHAPTER 3}

\section{IMMUNOMODULATORY FUNCTION OF SA-4-1BBL AND RAPAMYCIN ON iTreg CELL GENERATION}

\section{Introduction}

Allogeneic transplantation rejection is associated with activation and proliferation of effector cells that, along with the release of proinflammatory cytokines, result in tissue damage (106). The activities of Treg cells are now recognized as fundamental to the development and maintenance of immune tolerance and shown to inhibit alloreactive Tcell activation and effector cell function $(6,115)$ serving as an attractive therapeutic tool for inducing tolerance $(116,117)$. Numerous reports targeting Treg cells showed that by manipulating the numbers and/or function of Treg cells can decrease pathology in a wide range of contexts, such as autoimmunity and transplantation in preclinical models.

Allogeneic graft rejection is initiated and perpetuated primarily by $\mathrm{T}$ cells that respond to allogeneic MHC molecules via direct and indirect recognition pathways (210). The importance of $\mathrm{T}$ cells in allograft rejection is demonstrated by the acceptance of allogeneic grafts by nude mice primarily deficient in $\mathrm{T}$ cells. Furthermore, most of the immunosuppressive drugs used in clinical transplantation to control graft rejection are targeted at $\mathrm{T}$ cells. After recognition of allogeneic antigens via TCR, $\mathrm{T}$ cells get activated, proliferate, expand, and acquire effector functions that not only directly inflict damage to the graft but also initiate a series of other effector mechanisms, such as 
proinflammatory and humoral, that ultimately results in the destruction of the graft. Therefore, various immunosuppressive drugs have been developed that target various aspects of $\mathrm{T}$ cells activation and effector functions for the control of graft rejection. Most protocols use a combination of agents in a chronic fashion to achieve this goal. Although successful in preventing allograft rejection, the chronic use of these non-specific immunosuppressive drugs not only has direct toxic effects on the host and the graft, but also increases the risk of opportunistic infections and cancer due to a compromised immune response. Therefore, the ultimate goal of the transplantation field is to develop tolerogenic regimens that prevent graft rejection in the absence of immunosuppression while preserving immunocompetence. Although many current transplantation protocols require the use of immunosuppressive agents that targets calcineurin and mTOR pathways, a preference is developing towards specifically targeting the mTOR pathway for not merely the control of acute rejection, but also induction of tolerance in combination with regimens that are designed to achieve this goal. In this context, rapamycin emerged as the drug of choice.

Unlike other immunosuppressive agents that are designed to suppress Teff cells, rapamycin has several advantages as it not only effectively suppress Teff cells by arresting them in the cell cycle (211), but also facilitate the conversion of these cells into iTreg cells (120), (127). In addition, rapamycin does not negatively affect the activation and proliferation of nTreg cells. Importantly, rapamycin has been shown to change the behavior of DCs into a tolerogenic one. Collectively, these pleiotropic effects of rapamycin have the potential to induce tolerance in the absence of continuous use of nonspecific generalized immunosuppression. A series of studies have provided direct evidence for the pleiotropic effects of rapamycin on immune responses in preclinical and 
clinical settings. Inhibition of mTOR activity in mice causes marked decrease in $\mathrm{T}$ cell proportion in the periphery (211). Extended use of rapamycin administration blocks the conversion of thymocytes from double-negative $\left(\mathrm{CD}^{-} \mathrm{CD}^{-}\right)$to double-positive $\left(\mathrm{CD}^{+}\right.$ $\mathrm{CD}^{+}$) T cells in the thymus (212), thereby interfering with the development of Teff cells and potentially $\mathrm{nTreg}$ cells. Although rapamycin decreases the absolute number of $\mathrm{T}$ cells in the periphery, it does not alter the proportion of $\mathrm{CD}^{+} \mathrm{FoxP}^{+}$Treg cells in the periphery (127). This indicates that the nTreg cell population is unaffected by mTOR blockade mediated by rapamycin. Recent evidence suggests that FoxP3 expression in T cells is negatively regulated by the PI3K-AKT-mTOR pathway, which is shown by the blockade of FoxP3 upregulation in the presence of constitutive AKT activation (213). This suggest that rapamycin mediated blockade of mTOR will yield higher proportion of $\mathrm{CD}^{+}$cells that have upregulated expression of FoxP3.

Treg cell function and homeostasis are not affected by rapamycin as compared to its effect on Teff cells. Mouse or human Treg cells exposed to rapamycin in vitro have normal suppressive function on Teff cell proliferation (128). This is not the case when other immunosuppressive agents, such as calcineurin inhibitor cyclosporin A, are used $(214,215)$. In addition, extended administration of rapamycin in vivo results in a decrease in the absolute numbers of all $\mathrm{T}$ cells in face of an increase in the number of Treg cells $(127,129,215)$. These preclinical observations also apply to clinical settings as it was shown that patients who received kidney transplants when treated with rapamycin have a marked increase in the frequency of Treg cells as compared with total $\mathrm{CD}^{+} \mathrm{T}$ cell numbers $(129,216)$.

TGF- $\beta$ converts $C D 4^{+} \mathrm{CD} 25^{-} \mathrm{T}$ cells into FoxP3 expressing iTreg cells in the presence of TCR stimulation and IL-2 (217). The observation that both TGF- $\beta$ and 
rapamycin mediate the expression of FoxP3 in $\mathrm{T}$ cells led to investigations focused on common signaling pathways involved, especially the mTOR pathway. The induction of FoxP3 transcription by TGF- $\beta$ depends on the activation of the transcription factor SMAD3, which in combination with TCR signal activated NFAT, binds to the enhancer region of FoxP3 and initiate the transcription of this gene (132). T cells that are not treated with rapamycin, signaling through the mTOR pathway can inhibit the activation of SMAD3, thereby downregulating the expression of FoxP3 (133). The blockade of mTOR pathway by rapamycin leads to the activation of SMAD3 that in turn binds FoxP3 gene, upregulate its expression, and thereby converting Teff cells into iTreg cells. These aspects of rapamycin, therefore, qualify this drug as immunomodulatory component of therapeutic approaches targeting the induction of transplantation tolerance. For example, by using rapamycin in conjunction with blocking antibodies against $\mathrm{CXC}$-chemokine receptor 3 (CXCR3) and its ligands (CXCL9, CXCL10 and CXCL11) that are important for effector $\mathrm{T}$ cell recruitment, increased the survival rate of islet as well as heart allograft (218).

The synergetic activity of rapamycin with signal 3 , i.e. IL-2 or TGF- $\beta$, in expanding Treg cells or converting Teff cells into iTreg cells, suggests that rapamycin may be used in combination with signal 2 agents, such as costimulatory molecules of TNF family, to change the Teff:Treg balance in favor of Treg cells for the induction of transplantation tolerance. TNFR costimulatory molecules play an important role in regulating innate, adoptive and regulatory arms of the immune system. Costimulatory receptor $4-1 \mathrm{BB}$ is constitutively expressed on Treg cells and ligation of 4-1BB is effective in expanding these cells without loss of their immunosuppressive function ( 162 , 209). The 4-1BB expression on Treg cells may be advantageous for increasing their 
expansion or survival in the context of transplantation, provided that the positive impact of this signaling on Teff cells is simultaneously inhibited. In this context, rapamycin as an immunosuppressive drug known to preferentially block the cycling of Teff cells without a negative effect on Treg cells generation, proliferation, and effector function emerges as the immunosuppressive drug of choice $(127,128,130,219)$. Importantly, the positive effect of rapamycin on the conversion of conventional $\mathrm{CD}^{+} \mathrm{T}$ Cells into iTreg cells under TCR stimulation without impairment of their potent immunosuppressive activity $(131,220)$, provides additional incentive as the drug of choice and justifies the combinatorial use of 4-1BBL and rapamycin for the induction of tolerance.

We, therefore, conducted a series of in vitro studies as a prelude to in vivo tolerance induction efforts to test if 4-1BB costimulation works in synergy with rapamycin TCR stimulation and IL-2 to block the proliferative function of Teff cells and convert these cells into iTreg cells. Our data demonstrate that 4-1BBL stimulation induces the proliferation of Teff cells and rapamycin effectively block this proliferation for the generation of iTreg cells.

\section{Material and Methods}

\section{Mice and reagents}

$\mathrm{C} 57 \mathrm{BL} / 6$ and $\mathrm{BALB} / \mathrm{c}$ mice were purchased from Jackson Laboratories or bred in our animal facility. Mice were maintained under specific pathogen-free conditions at the University of Louisville (Louisville, KY) and used at the age of 8-10 weeks. This study was reviewed and approved by the Institutional Animal Care and Use Committee of the University of Louisville, and animals were cared for in accordance to institutional and National Institutes of Health guidelines. 


\section{$\mathrm{CD4}^{+} \mathrm{T}$ cell sorting from $\mathrm{C} 57 \mathrm{BL} / 6$ or $\mathrm{C} 57 \mathrm{BL} / 64 \mathrm{HBB}^{-1-}$ mice}

Spleen and lymph nodes from C57BL/6 or C57BL/6 $4-1 \mathrm{BB}^{-/ /}$mice were harvested and processed into single cell suspension, and RBCs were lysed using ACK solution. For CD4 cell sorting, cells were stained with CD25-PE, and CD4-APC. Naîve CD4 $4^{+} \mathrm{CD} 25^{-} \mathrm{T}$ cells were sorted using a FACSVantage and FACSAria cell sorters (BD Biosciences). Sorted cells were $>95 \%$ pure.

\section{Preparation of APCs from BALB/c}

For the preparation of APCs, spleen and lymph node cells from naïve BALB/c mice were depleted for T cells by first staining with anti $\alpha \beta-\mathrm{TCR} \mathrm{Ab}$ (clone H57-597) for 30 mins. Cells were washed and incubated with Low-Tox-M rabbit complement (Cedarlane Laboratories, Burlington, NC) for $60 \mathrm{~min}$ at $37^{\circ} \mathrm{C}$ for the lysis of $\mathrm{T}$ cells. After several washes with PBS, the live cells were irradiated with 2,000 cGy and used as APCs in coculture experiments with sorted $\mathrm{C} 57 \mathrm{BL} / 6$ or $\mathrm{C} 57 \mathrm{BL} / 64-1 \mathrm{BB}^{-/-} \mathrm{CD}^{+} \mathrm{T}$ cells. Cells were checked for $\mathrm{T}$ cell depletion using flow cytometry (Figure 4).

\section{In vitro $T$ cell cultures and phenotyping}

$5 \times 10^{5}$ cells $/ \mathrm{ml}$ of sorted naïve $\mathrm{CD} 4^{+} \mathrm{CD} 25^{-} \mathrm{T}$ cells from $\mathrm{C} 57 \mathrm{BL} / 6$ or $\mathrm{C} 57 \mathrm{BL} / 64-1 \mathrm{BB}^{-/-}$ mice were plated with $2 \times 10^{6}$ cells $/ \mathrm{ml}$ of $\mathrm{T}$ cell depleted APCs from BALB/c in the presence of varying concentration of rapamycin and cultured in complete MLR media for 4 days. SA-4-1BBL $(10 \mu \mathrm{g} / \mathrm{ml})$ or equimolar concentration of SA $(2.4 \mu \mathrm{g} / \mathrm{ml})$ as control and rIL-2 were also added to the cultures. Cultured cells were phenopyped using CD4 APC (Clone RM4-5) or CD4 PE (Clone GK1.5), CD25 PE or CD25 PE-Cy7 (Clone PC61). Intracellular FoxP3 staining was performed according to the manufacturer's 
protocol (eBioscience). Isotype Abs with matched fluorochromes were used as controls. All samples were collected using FACSCalibur or BD LSR II (BD Biosciences) and analyzed using FlowJo (Tree Star) or FACS Diva software respectively.

\section{$\underline{\text { Results }}$}

Rapamycin and IL-2 work in synergy to generate iTreg cells from alloreactive $\mathrm{CD4}^{+}$Teff cells

Given that IL-2 is required for the generation of iTreg cells, we first assessed the ability of various doses of rapamycin in combination with IL-2 on the growth and differentiation of naive $\mathrm{CD}^{+} \mathrm{T}$ cells and their conversion into iTreg cells in an allogeneic setting. To this purpose, sorted $\mathrm{CD}^{+} \mathrm{T}$ cells were stimulated with irradiated allogeneic APCs in the presence or absence of IL-2 and varying doses of rapamycin. Under normal allogeneic setting or in the presence of rapamycin, irrespective of its dose, we did not observe enhancement of the generation of $\mathrm{CD} 25^{+} \mathrm{FoxP} 3^{+}$iTreg cells (Figure 10). In marked contrast, rapamycin significantly increased the percentage of $\mathrm{CD} 25^{+} \mathrm{FoxP} 3^{+}$Treg cells in the presence of IL-2 (Figure 10). However, Treg proportions were reduced by higher dose of rapamycin (Figure 10). In conclusion, adding lower dose of rapamycin in the presence of IL-2 was advantageous in increasing the overall number of $\mathrm{CD}_{2} 5^{+} \mathrm{FoxP} 3^{+}$ iTreg cells.

\section{4-1BBL in the presence of IL-2 and rapamycin further increases the generation of $\mathrm{CD25}^{+} \mathrm{FoxP3}^{+}$iTreg cells from Teff cells}

Since the IL-2 and low dose of rapamycin preferentially generated iTreg cells and these cells express $4-1 \mathrm{BB}$ receptor, we next tested if costimulation with SA-4-1BBL further 
improves the efficacy of this regimen in further generating/expanding iTreg cells. Addition of SA-4-1BBL alone without IL-2 to allogeneic cultures in the presence of rapamycin significantly increased the proportion of iTreg cells in these cultures (Figure 11). More importantly, the combination of 4-1BBL, IL-2, and rapamycin had the most potent effect on the generation/expansion of iTreg cells (Figure 11). We also noticed that addition of rapamycin to the cultures significantly reduced the percentage of $\mathrm{CD}^{+}{ }^{+}$ox $\mathrm{P}^{+} \mathrm{T}$ cells expressing $\mathrm{CD} 25$, indicating that rapamycin preferentially blocks the proliferation of allogeneic $\mathrm{CD} 4^{+}$effector cells (Figure 11). Taken together, these data demonstrate that the provision of three signals (allogeneic TCR stimulation, 4-1BBL mediated co-stimulation, and IL-2 cytokine) in the presence of rapamycin is an effective and clinically applicable approach that effectively increases the generation/expansion of iTreg cells.

\section{4-1BB, but not CD28 signaling, is crucial for rapamycin mediated increase in the generation/expansion of iTreg cells}

Costimulation via CD28 is critical for the generation of nTreg cells. We, therefore, tested if this costimulatory signal also has similar effects on the generation of iTreg cells in the presence of rapamycin and how this effect compares with 4-1BB costimulation. To compare the ability of $\mathrm{CD} 28$ versus $4-1 \mathrm{BB}$ costimulation to increase the rapamycin/IL-2mediated generation of iTreg cells, we added anti-CD28 stimulating antibody to the cultures containing rapamycin and IL-2. To our surprise, CD28 costimulation was not able to enhance the generation of iTreg cells in the cultures containing rapamycin and IL2 (Figure 12). This data suggest that only $4-1 \mathrm{BB}$, but not $\mathrm{CD} 28$, signaling is efficacious in generating iTreg cells in synergy with rapamycin and IL-2. 


\section{$\underline{\text { Discussion }}$}

When we cultured naïve $\mathrm{CD} 4^{+} \mathrm{T}$ cells in an allogeneic setting in the presence of rapamycin, we observed two major effects. First, in order for rapamycin to convert these cells into $\mathrm{CD} 25^{+} \mathrm{FoxP} 3^{+}$iTreg cells, IL-2 is absolutely required. Rapamycin through mTOR inhibition is thought to skew towards the conversion of $\mathrm{CD}^{+} \mathrm{T}$ cells into iTreg by increased usage of the STAT5 pathway over the PI3K pathway in response to IL-2 (221) and in turn IL-2 receptor dependent STAT5 activation is required for FoxP3 transcription (222). Thus, the rapamycin mediated mTOR inhibition in the presence of IL-2 signaling favors the conversion/expansion of iTreg cells.

The second effect of rapamycin is decrease in the proliferation of these $\mathrm{CD}^{+}{ }^{+} \mathrm{FoxP} 3^{-} \mathrm{T}$ cells which correlates with decreased number of cells expressing CD25. The addition of rapamycin to the expansion culture was required for outgrowth of converted iTreg cells at the expense of Teff cells.

Prior reports indicated that 4-1BB signaling can expand Treg cells without losing their suppressive activity (12). Our data clearly demonstrate that in the absence of rapamycin, signaling through $4-1 \mathrm{BB}$ actually promoted the proliferation of $\mathrm{CD}^{+} \mathrm{FoxP}^{-}$ $\mathrm{T}$ cells. This is consistent with the previous studies showing that signaling through 4$1 \mathrm{BB}$ promotes the proliferation, survival and function of effector $\mathrm{CD} 4^{+}$and $\mathrm{CD} 8^{+} \mathrm{T}$ cells $(12,140)$. Importantly, 4-1BB signaling in the presence of rapamycin and IL-2 clearly increased the rapamycin converted iTreg cell as we observed higher percentage of cells expressing FoxP3 when cultures were added SA-4-1BBL along with rapamycin and IL-2 as compared to rapamycin or rapamycin and IL-2 cultures. 
It has been recently reported that $\mathrm{CD} 28$ signaling plays a crucial role in the development of Treg cells $(9,48)$ and these cells can be expanded in vitro using TCR and CD28 stimulation (223). Moreover, CD28 signaling acts earlier than 4-1BB due to its constitutive expression on naïve CD4 T cells. We compared the ability of CD28 signaling to $4-1 \mathrm{BB}$ in expanding the rapamycin converted iTreg cells. We observed that 4-1BB but not $\mathrm{CD} 28$ costimulation is effective in increasing the $\mathrm{CD}_{2} 5^{+} \mathrm{FoxP}^{+} \mathrm{T}$ cell proportion in the cultures. This suggests that 4-1BB delivers quantitatively or qualitatively different signals as compared to $\mathrm{CD} 28$ that allow expansion of rapamycin and IL-2 mediated iTreg cells.

The observed difference between 4-1BB and CD28 signaling might be due to differential expression kinetics and signaling pathways used by these costimulatory molecules. During conventional $\mathrm{T}$ cell activation, mTOR signaling integrates the TCR and $\mathrm{CD} 28$ signals to transit from $\mathrm{G} 0$ to $\mathrm{Gl}$ phase of the cell cycle which requires activation of NFAT (TCR induced), mitogen-activated protein kinases (MAPKs), AP1 (CD28 induced) and nuclear factor- $\mathrm{kB}(\mathrm{NF}-\mathrm{kB})(224)$. The coordinated activity of these factors determines the expression of many genes that are involved in cell cycle progression along with the expression of IL-2 and IL-2 receptor. Whereas, 4-1BB signaling in the presence of TCR signal leads to activation of JUN N-terminal kinase (JNK), AP1, MAPKs, ERK, NF-кB and NFAT. These molecules are involved in promoting the production of IL-2, IL-4, IL-5 and IFN- $\gamma$. Costimulation through both CD28 as well as 4-1BB results in the production of IL-2 and signaling through IL-2 receptor in turn activates mTOR through the PI3K-AKT-mediated signaling pathway which ultimately lead to G1 to S phase progression. So, both costimulatory molecules 
indirectly use the mTOR pathway for promoting cell cycling. In the current study, we block the mTOR pathway using rapamycin, but still see an increase in the FoxP3 iTreg cells when we add SA-4-1BBL but not $\alpha$-CD28 activating antibody. The reason for this observed discrepancy might be due to other signaling pathways that might be involved or used by $4-1 \mathrm{BB}$ signaling in promoting the expression of FoxP3. Another reason for this differential effect of CD28 and 4-1BB signaling might lie in the expression kinetics of $\mathrm{CD} 28$ and $4-1 \mathrm{BB}$. $\mathrm{CD} 28$ and $4-1 \mathrm{BB}$ are expressed at various time points during the activation of $\mathrm{T}$ cells. CD28 is constitutively expressed on T cells and acts initially during the $\mathrm{T}$ cell activation. Whereas, $4-1 \mathrm{BB}$ is expressed later after $\mathrm{T}$ cell and $\mathrm{CD} 28$ stimulation, and is only induced on T cells after activation. Further signaling studies on these two costimulatory molecules and the factors they recruit will shed more light on the differential effects we have observed in this study.

In conclusion, we have shown that low dose of rapamycin in the presence of IL-2 signaling promotes the conversion of naïve $\mathrm{CD}^{+} \mathrm{T}$ cells into iTreg cells. 4-1BB signaling further promotes the expansion of iTreg cells in a synergistic manner. Furthermore, CD28 signaling did not promote the expansion of iTreg cells in contrast to 4-1BB signaling. These data not only have important implications for inducing Treg cells in transplantation setting, but also provide novel insights into the biologic effects of 41BBL on Treg cell expansion. 


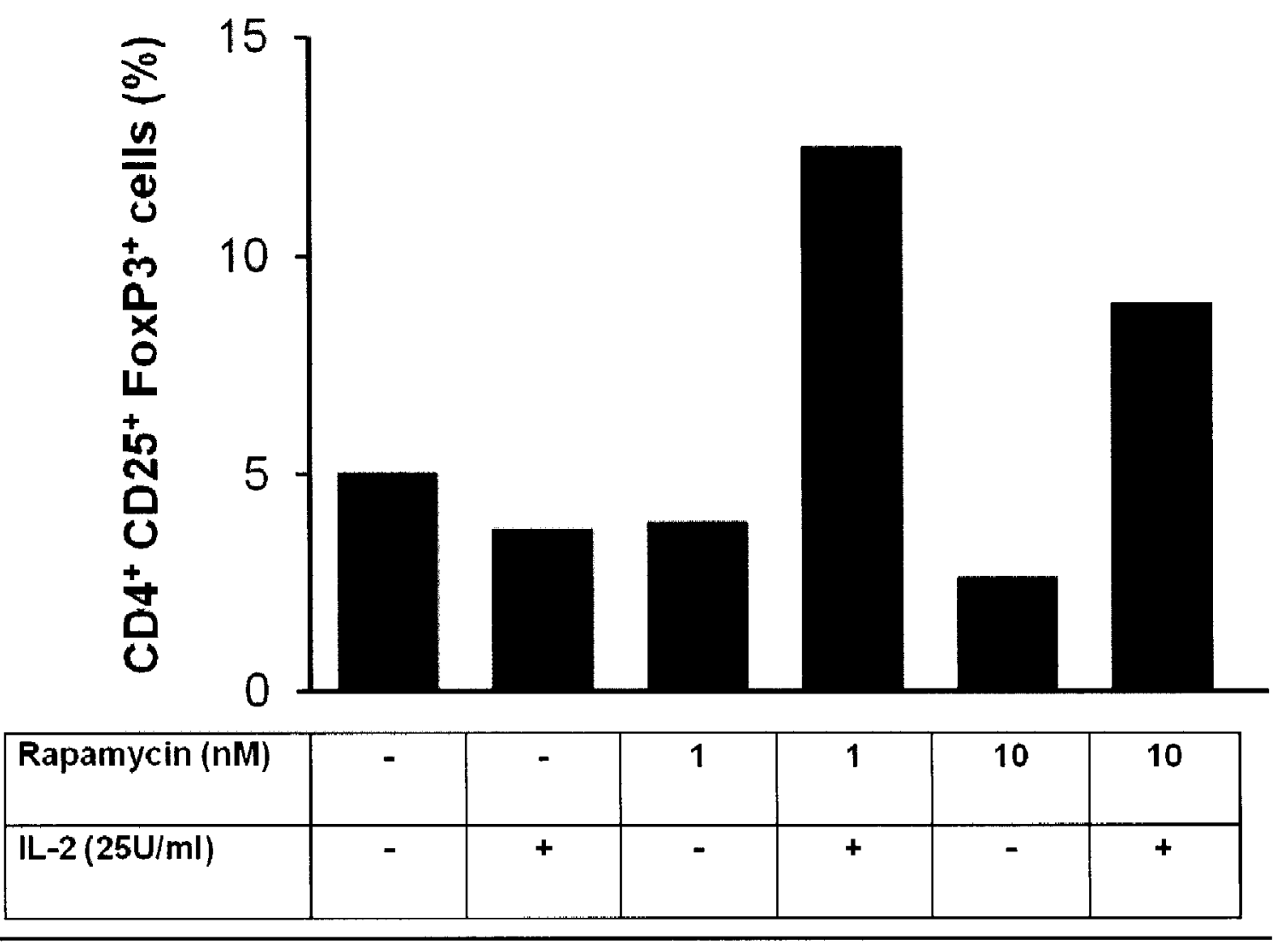

Figure 10. Lower dose of rapamycin in the presence of IL-2 is effective in increasing the $\mathrm{CD}^{2} 5^{+} \mathrm{FoxP} 3^{+} \mathrm{T}$ cell proportion. Naïve $\mathrm{CD}^{+} \mathrm{CD}^{-} 5^{-} \mathrm{T}$ cells from $\mathrm{C} 57 \mathrm{BL} / 6$ mice were cultured with BALB/c APCs ( $T$ cell depleted) and with various doses of rapamycin (1 $\mathrm{nM}$ and $10 \mathrm{nM})$ in the presence or absence of IL-2 $(25 \mathrm{U} / \mathrm{ml})$. After 4 days, cells were evaluated for CD25 and intracellular FoxP3 by gating on CD4 population using flow cytometry. Data is representative of at least two independent experiments. 


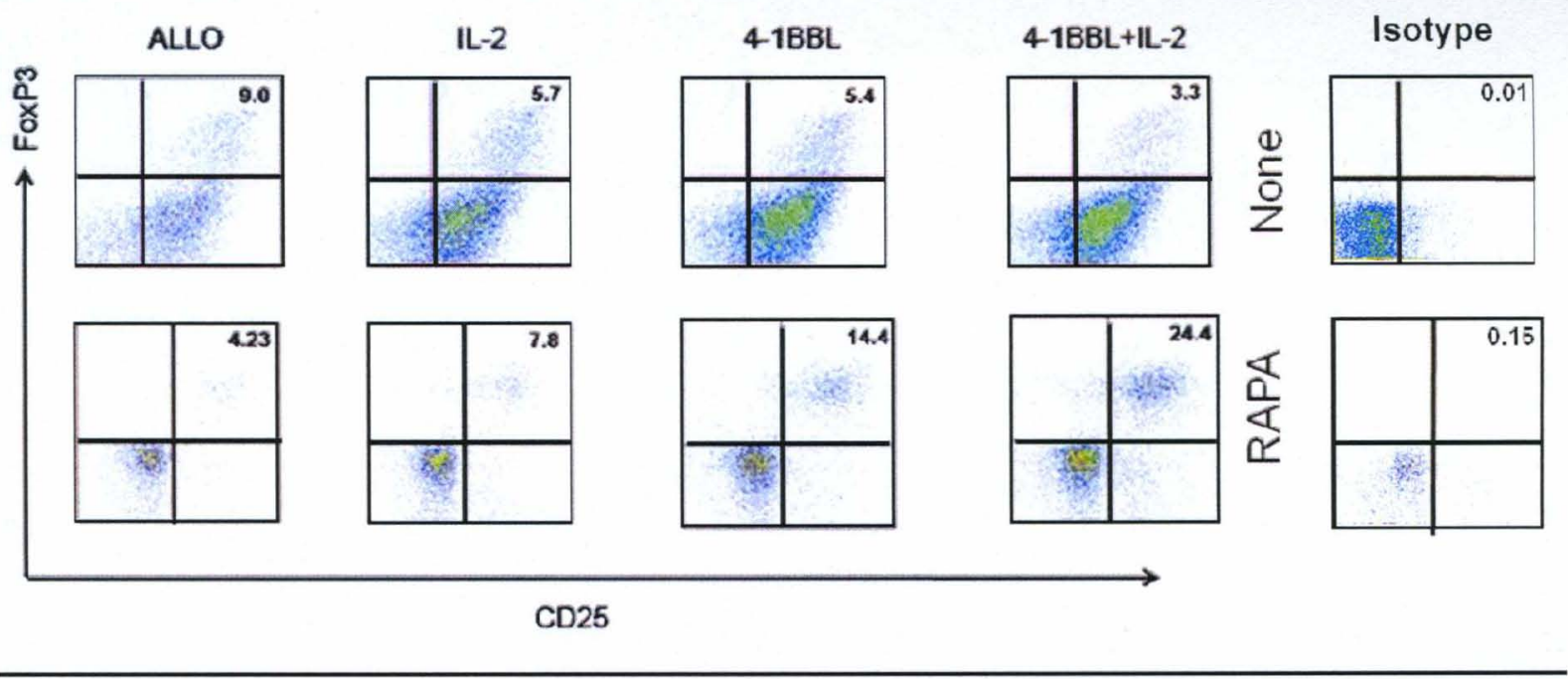

Figure 11. Synergy between SA-4-1BBL and IL-2 in increasing the $\mathrm{CD}_{2} 5^{+} \mathrm{FoxP}^{+} \mathrm{T}$ cell proportion in the presence of low dose of rapamycin. Naïve CD4 ${ }^{+} \mathrm{CD}^{-} 5^{-} \mathrm{T}$ cells from C57BL/6 mice were cultured with BALB/c APCs (T cell depleted) and with or without rapamycin $(1 \mathrm{nM})$ in the presence or absence of IL-2 $(25 \mathrm{U} / \mathrm{ml})$, and SA-4-1BBL $(10 \mu \mathrm{g} / \mathrm{ml})$ or in combination. After 4 days, cells were evaluated for CD25 and intracellular FoxP3 by gating on CD4 population using flow cytometry. Cells from with and without rapamycin cultures were also stained for isotype antibodies for CD25 and FoxP3 and gating was adjusted according to the isotype quadrants. Data is representative of at least three independent experiments. 


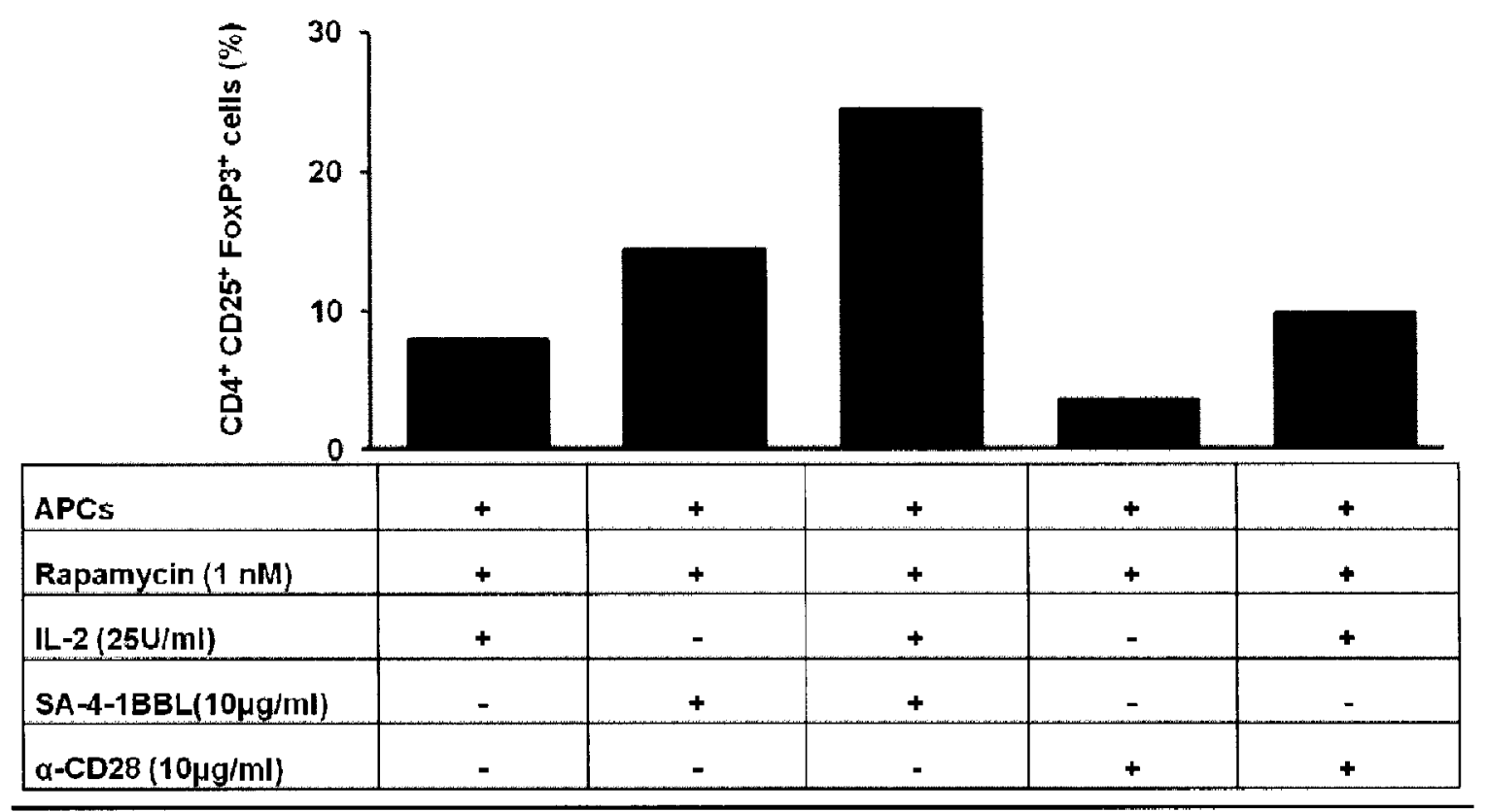

Figure 12. $4-1 \mathrm{BB}$ but not $\mathrm{CD} 28$ costimulation is effective in increasing the $\mathrm{CD}^{2} 5^{+} \mathrm{FoxP} 3^{+} \mathrm{T}$ cell proportion. Naïve $\mathrm{CD}^{+} \mathrm{CD} 25^{-} \mathrm{T}$ cells from $\mathrm{C} 57 \mathrm{BL} / 6$ mice were cultured with BALB/c APCs (T cell depleted) and with rapamycin $(1 \mathrm{nM})$ in the presence or absence of IL-2 $(25 \mathrm{U} / \mathrm{ml})$. SA-4-1BBL $(10 \mu \mathrm{g} / \mathrm{ml})$ or anti-CD28 $\mathrm{Ab}(10 \mu \mathrm{g} / \mathrm{ml})$ were also added to the culture with or without IL-2. After 4 days, cells were evaluated for $\mathrm{CD} 25$ and intracellular FoxP3 by gating on CD4 population using flow cytometry. Data is representative of at least two independent experiments. 


\section{CHAPTER 4}

\section{CONCLUSIONS AND FUTURE PERSPECTIVES}

Signaling through TNF receptors play a critical role in modulating adaptive, innate and regulatory immunity with important therapeutic implications in settings of autoimmunity, transplantation, cancer, and chronic infections. In the context of regulatory immunity, signaling via $4-1 \mathrm{BB}$ receptor may have diverse and opposing consequences and can modulate the development and activity of regulatory $\mathrm{T}$ cells. For example, we (185) and others $(199,200)$ have previously demonstrated that signaling via 4-1BB on naturally occurring Treg cells serves to promote their proliferation and/or survival in vitro in the presence of exogenous IL-2. However, signaling via 4-1BB on T effector cells antagonizes the suppressive function of of Treg cells thereby endowing these cells to be refractory to inhibition by Treg cells (185) via yet to be defined mechanisms. Although, the physiological consequence of these opposing effects of 41BB signaling during the course of an immune response is not obvious, it might serve as a homeostatic mechanism dictated by the expression kinetics, expression profile on various cells and the availability of 4-1BB and its ligand. This outcome may be regulated by transient interaction between 4-1BBL inducible expressed on APCs with 4-1BB on Treg and Teff cells in the course of ongoing immune responses. The present study reveals another important and novel function of $4-1 \mathrm{BB}$ signaling on regulating the 
balance between adaptive and regulatory immunity. First, when 4-1BBL was used under low dose antigenic stimulation or in the presence of TGF- $\beta$, it blocked the de novo generation of iTreg cells from naïve T cells. Importantly, in the presence of rapamycin, 4-1BB signaling played an opposing role by augmenting the conversion of Teff cells into iTreg cells.

Inhibition of the conversion of naïve $\mathrm{CD} 4^{+} \mathrm{T}$ cells to iTreg cells or augmentation of conversion of Teff cells into iTreg cells mediated by 4-1BB signaling poise this pathway with significant potential for therapeutic interventions in setting where Teff and Treg cells serve as major culprit of the disease. As shown in Fig. 13, cancer suffers from increased number of Treg cells and decreased number of Teff cells that also serve as a major barrier for the success of immunotherapeutic interventions. Therefore, modulation of 4-1BB signaling using a well defined approach with the efficacy of effectively reversing this balance will have desired therapeutic implications. In marked contrast, in the setting of transplantation and autoimmunity where the excess of Teff cells perpetuate the disease, reversing the balance of Teff:Treg in favor of Treg cells by exploiting 4-1BB signaling will serve an important therapeutic application. However, given the pleiotropic effects of 4-1BB signaling in the immune system, a better understanding of mechanistic basis of how 4-1BB signaling affects various cells of the immune system and the conditions that will allow a controlled manipulation of these effect for therapeutic ends will be required to maximize the efficacy over toxicity.

Accumulating evidence has shown that interaction between 4-1BB and 4-1BBL plays an important role in controlling $\mathrm{T}$ cell function and immune regulation. There are still great gaps in our knowledge regarding the activity, expression characteristics and 
involvement of 4-1BB signaling on various cell types and at various stages of the immune response during infections. In the case of Treg cell based immunomodulation for treatment of cancer and autoimmunity, it is important to know the signaling consequences of 4-1BB in controlling the expression of FoxP3. It is also important to know the effect and nature of 4-1BB signaling on the proliferation, survival, and regulatory function of both nTreg as well as iTreg cells and different mechanisms and the signaling utilized by these cells for suppression. Without first understanding how nTreg and iTreg cells suppress, it will not be possible to fully understand the differential effects of 4-1BB signaling on various subsets of Treg cells as well as Teff cells. Another issue that needs to be resolved is whether there are functional differences between nTreg and iTreg cells, and the stability of FoxP3 expression on these cell types. It is also important to exploit the receptors that are constitutively or inducibly expressed by Treg cells, and what role these receptors play in the function of these cells. More studies are are required to show the importance of the balance between Teff to Treg cell during various immune responses and disease settings. Further research will provide new information regarding the potential usefulness of $4-1 \mathrm{BB}$ costimulation in different therapeutic settings. 


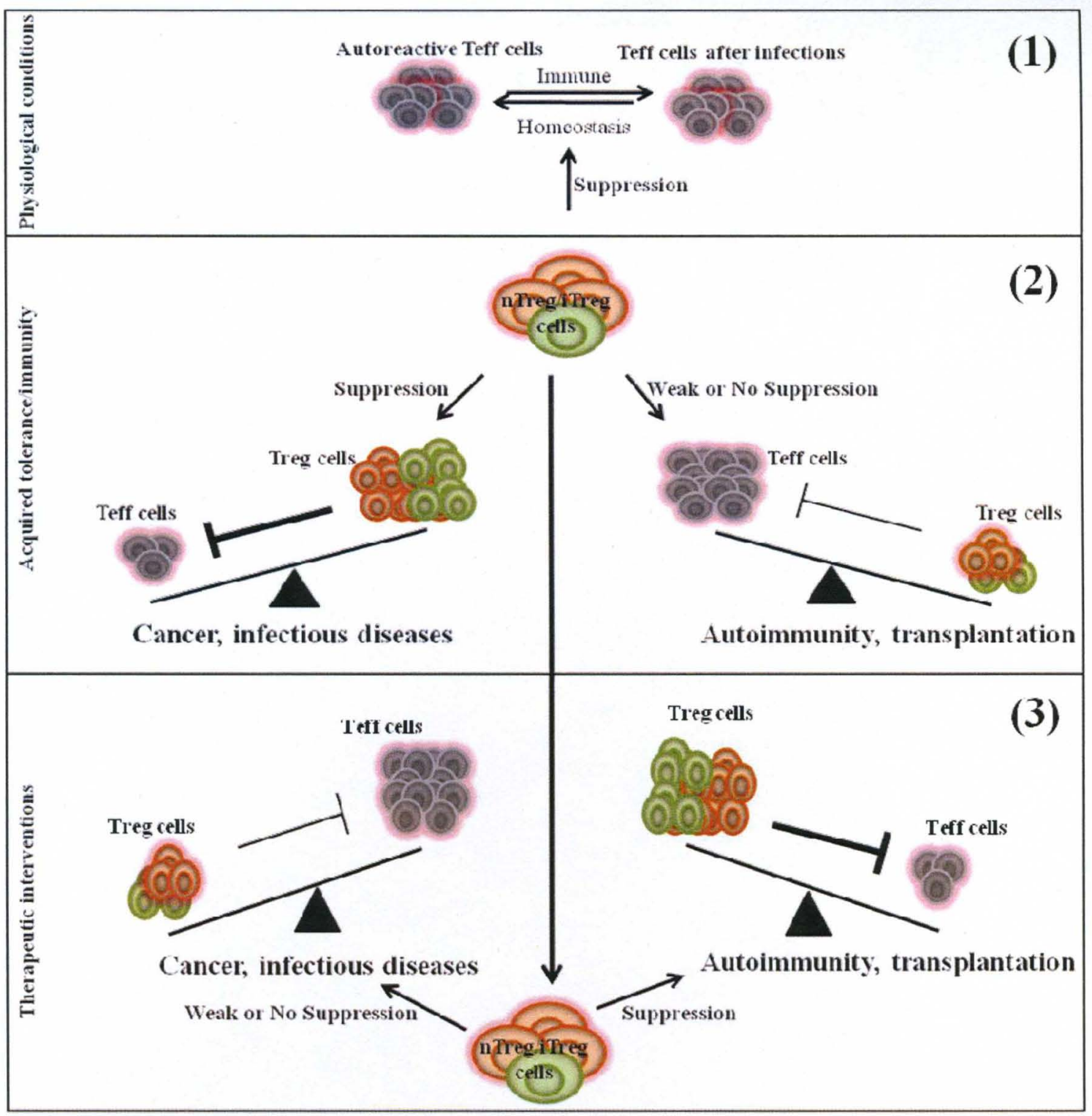

Figure 13. Schematic diagram showing the possible roles played by Treg cells in various disease setting and potential interventions by targeting Treg cells. (1) Under normal physiological conditions, Treg cells are required in the periphery to control autoreactive Teff cells as well as regulating the post-infection Teff cells. (2) In disease setting like cancer and autoimmunity, abnormal function of Treg cells exacerbate the disease condition. In case of cancer, Treg cells accumulate within the tumor and in the secondary lymphoid organs as a result of tumor-mediated recruitment and/or expansion of 
preexisting nTreg cells or conversion of naive Teff cells into induced iTreg cells. Treg cells then suppress anti-tumor immune responses by targeting cells of innate, adaptive, and humoral immunity, thereby promoting tumor progression. In case of autoimmunity and transplantation, lack of Treg cell number and/or function leads to excessive immune response by auto-reactive or allo-antigen specific Teff cells, leading to tissue damage and organ failure. (3) The goal of therapeutic interventions in case of cancers is to lower the Treg cell number and/or function as well as inhibiting the conversion of naïve $\mathrm{CD}^{+} \mathrm{T}$ cells to iTreg cells (shown in this study). This in turn will facilitate an effective Teff cell response for eradication of tumors. This has important implications for the treatment of cancer that exploits Treg cells for immune evasion and requires a Th1 dominated response for immunotherapy. In the context of autoimmunity and transplantation, increasing the Treg cell number and/or function and enhancing the rate of conversion of $\mathrm{CD}^{+} \mathrm{T}$ cells into iTreg cells might be beneficial for the induction of transplantation tolerance. 


\section{REFERENCES}

(1) Sakaguchi S, Sakaguchi N, Asano M, Itoh M, Toda M. Immunologic selftolerance maintained by activated $\mathrm{T}$ cells expressing IL-2 receptor alpha-chains (CD25). Breakdown of a single mechanism of self-tolerance causes various autoimmune diseases. J Immunol 1995;155:1151-64.

(2) Curiel TJ, Coukos G, Zou L, Alvarez X, Cheng P, Mottram P, et al. Specific recruitment of regulatory $\mathrm{T}$ cells in ovarian carcinoma fosters immune privilege and predicts reduced survival. Nat Med 2004;10:942-9.

(3) Gobert M, Treilleux I, Bendriss-Vermare N, Bachelot T, Goddard-Leon S, Arfi V, et al. Regulatory $\mathrm{T}$ cells recruited through CCL22/CCR 4 are selectively activated in lymphoid infiltrates surrounding primary breast tumors and lead to an adverse clinical outcome. Cancer Res 2009;69:2000-9.

(4) Kawaida H, Kono K, Takahashi A, Sugai H, Mimura K, Miyagawa N, et al. Distribution of $\mathrm{CD} 4+\mathrm{CD} 25$ high regulatory $\mathrm{T}$-cells in tumor-draining lymph nodes in patients with gastric cancer. J Surg Res 2005;124:151-7.

(5) Nishikawa H, Kato T, Tanida K, Hiasa A, Tawara I, Ikeda H, et al. CD4+ CD25+ $\mathrm{T}$ cells responding to serologically defined autoantigens suppress antitumor immune responses. Proc Natl Acad Sci U S A 2003;100:10902-6.

(6) Sakaguchi S, Ono M, Setoguchi R, Yagi H, Hori S, Fehervari Z, et al. FoxP3+ $\mathrm{CD} 25+\mathrm{CD} 4+$ natural regulatory $\mathrm{T}$ cells in dominant self-tolerance and autoimmune disease. Immunol Rev 2006;212:8-27.

(7) Taylor PA, Noelle RJ, Blazar BR. CD4(+)CD25(+) immune regulatory cells are required for induction of tolerance to alloantigen via costimulatory blockade. $\mathrm{J}$ Exp Med 2001;193:1311-8.

(8) Zhou G, Levitsky HI. Natural regulatory T cells and de novo-induced regulatory T cells contribute independently to tumor-specific tolerance. J Immunol 2007;178:2155-62.

(9) Salomon B, Lenschow DJ, Rhee L, Ashourian N, Singh B, Sharpe A, et al. $\mathrm{B} 7 / \mathrm{CD} 28$ costimulation is essential for the homeostasis of the CD4+CD25+ immunoregulatory $\mathrm{T}$ cells that control autoimmune diabetes. Immunity 2000;12:431-40. 
(10) Larkin J, III, Rankin AL, Picca CC, Riley MP, Jenks SA, Sant AJ, et al. $\mathrm{CD} 4+\mathrm{CD} 25+$ regulatory $\mathrm{T}$ cell repertoire formation shaped by differential presentation of peptides from a self-antigen. J Immunol 2008;180:2149-57.

(11) Aggarwal BB. Signalling pathways of the TNF superfamily: a double-edged sword. Nat Rev Immunol 2003;3:745-56.

(12) Elpek KG, Yolcu ES, Franke DD, Lacelle C, Schabowsky RH, Shirwan H. Ex vivo expansion of $\mathrm{CD} 4+\mathrm{CD} 25+\mathrm{FoxP} 3+\mathrm{T}$ regulatory cells based on synergy between IL-2 and 4-1BB signaling. J Immunol 2007;179:7295-304.

(13) Ruby CE, Yates MA, Hirschhorn-Cymerman D, Chlebeck P, Wolchok JD, Houghton AN, et al. Cutting Edge: OX40 agonists can drive regulatory $\mathrm{T}$ cell expansion if the cytokine milieu is right. J Immunol 2009;183:4853-7.

(14) Sharma RK, Elpek KG, Yolcu ES, Schabowsky RH, Zhao H, Bandura-Morgan L, et al. Costimulation as a platform for the development of vaccines: a peptidebased vaccine containing a novel form of 4-1BB ligand eradicates established tumors. Cancer Res 2009;69:4319-26.

(15) Sharma RK, Schabowsky RH, Srivastava AK, Elpek KG, Madireddi S, Zhao H, et al. 4-1BB ligand as an effective multifunctional immunomodulator and antigen delivery vehicle for the development of therapeutic cancer vaccines. Cancer Res 2010;70:3945-54.

(16) Sharma RK, Srivastava AK, Yolcu ES, Macleod KJ, Schabowsky RH, Madireddi $\mathrm{S}$, et al. SA-4-1BBL as the immunomodulatory component of a HPV-16 E7 protein based vaccine shows robust therapeutic efficacy in a mouse cervical cancer model. Vaccine 2010.

(17) von $\mathrm{BH}$, Kisielow $\mathrm{P}$. Self-nonself discrimination by $\mathrm{T}$ cells. Science 1990;248:1369-73.

(18) Hsieh CS, Rudensky AY. The role of TCR specificity in naturally arising CD25+ CD4+ regulatory T cell biology. Curr Top Microbiol Immunol 2005;293:25-42.

(19) Surh CD, Sprent J. T-cell apoptosis detected in situ during positive and negative selection in the thymus. Nature 1994;372:100-3.

(20) Webb S, Morris C, Sprent J. Extrathymic tolerance of mature T cells: clonal elimination as a consequence of immunity. Cell 1990;63:1249-56.

(21) Jones LA, Chin LT, Merriam GR, Nelson LM, Kruisbeck AM. Failure of clonal deletion in neonatally thymectomized mice: tolerance is preserved through clonal anergy. J Exp Med 1990;172:1277-85.

(22) Belardelli F. Role of interferons and other cytokines in the regulation of the immune response. APMIS 1995;103:161-79. 
(23) Balandina A, Lecart S, Dartevelle P, Saoudi A, Berrih-Aknin S. Functional defect of regulatory $\mathrm{CD} 4(+) \mathrm{CD} 25+\mathrm{T}$ cells in the thymus of patients with autoimmune myasthenia gravis. Blood 2005;105:735-41.

(24) Brunkow ME, Jeffery EW, Hjerrild KA, Paeper B, Clark LB, Yasayko SA, et al. Disruption of a new forkhead/winged-helix protein, scurfin, results in the fatal lymphoproliferative disorder of the scurfy mouse. Nat Genet 2001;27:68-73.

(25) Chen Z, Herman AE, Matos M, Mathis D, Benoist C. Where CD4+CD25+ T reg cells impinge on autoimmune diabetes. J Exp Med 2005;202:1387-97.

(26) Huan J, Culbertson N, Spencer L, Bartholomew R, Burrows GG, Chou YK, et al. Decreased FOXP3 levels in multiple sclerosis patients. J Neurosci Res 2005;81:45-52.

(27) Wildin RS, Ramsdell F, Peake J, Faravelli F, Casanova JL, Buist N, et al. Xlinked neonatal diabetes mellitus, enteropathy and endocrinopathy syndrome is the human equivalent of mouse scurfy. Nat Genet 2001;27:18-20.

(28) DiPaolo RJ, Brinster C, Davidson TS, Andersson J, Glass D, Shevach EM. Autoantigen-specific TGFbeta-induced FoxP3 + regulatory $T$ cells prevent autoimmunity by inhibiting dendritic cells from activating autoreactive $\mathrm{T}$ cells. J Immunol 2007;179:4685-93.

(29) Green EA, Gorelik L, McGregor CM, Tran EH, Flavell RA. CD4+CD25+ T regulatory cells control anti-islet CD8+ $\mathrm{T}$ cells through TGF-beta-TGF-beta receptor interactions in type 1 diabetes. Proc Natl Acad Sci U S A 2003; $100: 10878-83$.

(30) Hanash AM, Levy RB. Donor CD4+CD25+ T cells promote engraftment and tolerance following MHC-mismatched hematopoietic cell transplantation. Blood 2005;105:1828-36.

(31) Hoffmann P, Ermann J, Edinger M, Fathman CG, Strober S. Donor-type $\mathrm{CD} 4(+) \mathrm{CD} 25(+)$ regulatory $\mathrm{T}$ cells suppress lethal acute graft-versus-host disease after allogeneic bone marrow transplantation. J Exp Med 2002;196:389-99.

(32) Joffre O, Gorsse N, Romagnoli P, Hudrisier D, van Meerwijk JP. Induction of antigen-specific tolerance to bone marrow allografts with $\mathrm{CD} 4+\mathrm{CD} 25+\mathrm{T}$ lymphocytes. Blood 2004;103:4216-21.

(33) Selvaraj RK, Geiger TL. Mitigation of experimental allergic encephalomyelitis by TGF-beta induced FoxP3+ regulatory $\mathrm{T}$ lymphocytes through the induction of anergy and infectious tolerance. J Immunol 2008;180:2830-8.

(34) Shimizu J, Yamazaki S, Sakaguchi S. Induction of tumor immunity by removing CD25+CD4+ $\mathrm{T}$ cells: a common basis between tumor immunity and autoimmunity. J Immunol 1999;163:5211-8. 
(35) Yang ZZ, Novak AJ, Stenson MJ, Witzig TE, Ansell SM. Intratumoral CD4+CD25+ regulatory T-cell-mediated suppression of infiltrating CD4+ T cells in B-cell non-Hodgkin lymphoma. Blood 2006;107:3639-46.

(36) Yu P, Lee Y, Liu W, Krausz T, Chong A, Schreiber H, et al. Intratumor depletion of $\mathrm{CD} 4+$ cells unmasks tumor immunogenicity leading to the rejection of latestage tumors. J Exp Med 2005;201:779-91.

(37) Apostolou I, Sarukhan A, Klein L, von BH. Origin of regulatory $\mathrm{T}$ cells with known specificity for antigen. Nat Immunol 2002;3:756-63.

(38) Bensinger SJ, Bandeira A, Jordan MS, Caton AJ, Laufer TM. Major histocompatibility complex class II-positive cortical epithelium mediates the selection of CD4(+)25(+) immunoregulatory T cells. J Exp Med 2001;194:42738.

(39) Fontenot JD, Rasmussen JP, Williams LM, Dooley JL, Farr AG, Rudensky AY. Regulatory $\mathrm{T}$ cell lineage specification by the forkhead transcription factor FoxP3. Immunity 2005;22:329-41.

(40) Jordan MS, Boesteanu A, Reed AJ, Petrone AL, Holenbeck AE, Lerman MA, et al. Thymic selection of $\mathrm{CD} 4+\mathrm{CD} 25+$ regulatory $\mathrm{T}$ cells induced by an agonist self-peptide. Nat Immunol 2001;2:301-6.

(41) Modigliani Y, Bandeira A, Coutinho A. A model for developmentally acquired thymus-dependent tolerance to central and peripheral antigens. Immunol Rev 1996;149:155-20.

(42) Sakaguchi S. Policing the regulators. Nat Immunol 2001;2:283-4.

(43) Itoh M, Takahashi T, Sakaguchi N, Kuniyasu Y, Shimizu J, Otsuka F, et al. Thymus and autoimmunity: production of $\mathrm{CD} 25+\mathrm{CD} 4+$ naturally anergic and suppressive $\mathrm{T}$ cells as a key function of the thymus in maintaining immunologic self-tolerance. J Immunol 1999;162:5317-26.

(44) Papiernik M, de Moraes ML, Pontoux C, Vasseur F, Penit C. Regulatory CD4 T cells: expression of IL-2R alpha chain, resistance to clonal deletion and IL-2 dependency. Int Immunol 1998;10:371-8.

(45) Stephens LA, Mason D. CD25 is a marker for CD4+ thymocytes that prevent autoimmune diabetes in rats, but peripheral $\mathrm{T}$ cells with this function are found in both CD25+ and. J Immunol 2000;165:3105-10.

(46) Shimizu J, Yamazaki S, Takahashi T, Ishida Y, Sakaguchi S. Stimulation of CD25(+)CD4(+) regulatory $\mathrm{T}$ cells through GITR breaks immunological selftolerance. Nat Immunol 2002;3:135-42.

(47) Fehervari Z, Sakaguchi S. Development and function of CD25+CD4+ regulatory T cells. Curr Opin Immunol 2004;16:203-8. 
(48) Tai X, Cowan M, Feigenbaum L, Singer A. CD28 costimulation of developing thymocytes induces FoxP3 expression and regulatory $\mathrm{T}$ cell differentiation independently of interleukin 2 . Nat Immunol 2005;6:152-62.

(49) Malek TR, Bayer AL. Tolerance, not immunity, crucially depends on IL-2. Nat Rev Immunol 2004;4:665-74.

(50) Furtado GC, Curotto de Lafaille MA, Kutchukhidze N, Lafaille JJ. Interleukin 2 signaling is required for $\mathrm{CD} 4(+)$ regulatory $\mathrm{T}$ cell function. J Exp Med 2002;196:851-7.

(51) Bennett CL, Christie J, Ramsdell F, Brunkow ME, Ferguson PJ, Whitesell L, et al. The immune dysregulation, polyendocrinopathy, enteropathy, X-linked syndrome (IPEX) is caused by mutations of FOXP3. Nat Genet 2001;27:20-1.

(52) Chatila TA, Blaeser F, Ho N, Lederman HM, Voulgaropoulos C, Helms C, et al. JM2, encoding a fork head-related protein, is mutated in X-linked autoimmunityallergic disregulation syndrome. J Clin Invest 2000;106:R75-R81.

(53) Fontenot JD, Gavin MA, Rudensky AY. FoxP3 programs the development and function of CD4+CD25+ regulatory T cells. Nat Immunol 2003;4:330-6.

(54) Godfrey VL, Wilkinson JE, Russell LB. X-linked lymphoreticular disease in the scurfy (sf) mutant mouse. Am J Pathol 1991;138:1379-87.

(55) Schubert LA, Jeffery E, Zhang Y, Ramsdell F, Ziegler SF. Scurfin (FOXP3) acts as a repressor of transcription and regulates $\mathrm{T}$ cell activation. J Biol Chem 2001;276:37672-9.

(56) Wang J, Ioan-Facsinay A, van der Voort EI, Huizinga TW, Toes RE. Transient expression of FOXP3 in human activated nonregulatory CD4+ T cells. Eur J Immunol 2007;37:129-38.

(57) Gavin MA, Torgerson TR, Houston E, DeRoos P, Ho WY, Stray-Pedersen A, et al. Single-cell analysis of normal and FOXP3-mutant human T cells: FOXP3 expression without regulatory $\mathrm{T}$ cell development. Proc Natl Acad Sci U S A 2006;103:6659-64.

(58) Mantel PY, Ouaked N, Ruckert B, Karagiannidis C, Welz R, Blaser K, et al. Molecular mechanisms underlying FOXP3 induction in human T cells. J Immunol 2006; 176:3593-602.

(59) Morgan ME, van Bilsen JH, Bakker AM, Heemskerk B, Schilham MW, Hartgers $\mathrm{FC}$, et al. Expression of FOXP3 mRNA is not confined to CD4+CD25+ T regulatory cells in humans. Hum Immunol 2005;66:13-20.

(60) Walker MR, Kasprowicz DJ, Gersuk VH, Benard A, Van LM, Buckner JH, et al. Induction of FoxP3 and acquisition of T regulatory activity by stimulated human CD4+. J Clin Invest 2003;112:1437-43. 
(61) Singh B, Read S, Asseman C, Malmstrom V, Mottet C, Stephens LA, et al. Control of intestinal inflammation by regulatory $\mathrm{T}$ cells. Immunol Rev $2001 ; 182: 190-200$.

(62) Sakaguchi S, Fukuma K, Kuribayashi K, Masuda T. Organ-specific autoimmune diseases induced in mice by elimination of $\mathrm{T}$ cell subset. I. Evidence for the active participation of $\mathrm{T}$ cells in natural self-tolerance; deficit of a $\mathrm{T}$ cell subset as a possible cause of autoimmune disease. J Exp Med 1985;161:72-87.

(63) Smith H, Lou YH, Lacy P, Tung KS. Tolerance mechanism in experimental ovarian and gastric autoimmune diseases. J Immunol 1992;149:2212-8.

(64) Sugihara S, Izumi Y, Yoshioka T, Yagi H, Tsujimura T, Tarutani $O$, et al. Autoimmune thyroiditis induced in mice depleted of particular $\mathrm{T}$ cell subsets. I. Requirement of Lyt-1 dull L3T4 bright normal $\mathrm{T}$ cells for the induction of thyroiditis. J Immunol 1988;141:105-13.

(65) Apostolou I, von BH. In vivo instruction of suppressor commitment in naive T cells. J Exp Med 2004;199:1401-8.

(66) Chen W, Jin W, Hardegen N, Lei KJ, Li L, Marinos N, et al. Conversion of peripheral CD4+. J Exp Med 2003;198:1875-86.

(67) Kretschmer K, Apostolou I, Hawiger D, Khazaie K, Nussenzweig MC, von BH. Inducing and expanding regulatory $\mathrm{T}$ cell populations by foreign antigen. Nat Immunol 2005;6:1219-27.

(68) Curotto de Lafaille MA, Lino AC, Kutchukhidze N, Lafaille JJ. J Immunol 2004;173:7259-68.

(69) Fantini MC, Becker C, Monteleone G, Pallone F, Galle PR, Neurath MF. Cutting edge: TGF-beta induces a regulatory phenotype in $\mathrm{CD} 4+. \mathrm{J}$ Immunol 2004;172:5149-53.

(70) Josefowicz SZ, Rudensky A. Control of regulatory T cell lineage commitment and maintenance. Immunity 2009;30:616-25.

(71) Knoechel B, Lohr J, Kahn E, Bluestone JA, Abbas AK. Sequential development of interleukin 2-dependent effector and regulatory $\mathrm{T}$ cells in response to endogenous systemic antigen. J Exp Med 2005;202:1375-86.

(72) Liang S, Alard P, Zhao Y, Parnell S, Clark SL, Kosiewicz MM. Conversion of CD4+. J Exp Med 2005;201:127-37.

(73) Zheng SG, Wang J, Wang P, Gray JD, Horwitz DA. IL-2 is essential for TGFbeta to convert naive CD4+. J Immunol 2007;178:2018-27. 
(74) Zheng SG, Wang JH, Stohl W, Kim KS, Gray JD, Horwitz DA. TGF-beta requires CTLA-4 early after $\mathrm{T}$ cell activation to induce FoxP3 and generate adaptive CD4+CD25+ regulatory cells. J Immunol 2006;176:3321-9.

(75) Aricha R, Feferman T, Fuchs S, Souroujon MC. Ex vivo generated regulatory $\mathrm{T}$ cells modulate experimental autoimmune myasthenia gravis. J Immunol 2008;180:2132-9.

(76) Hill JA, Feuerer M, Tash K, Haxhinasto S, Perez J, Melamed R, et al. FoxP3 transcription-factor-dependent and -independent regulation of the regulatory $\mathrm{T}$ cell transcriptional signature. Immunity 2007;27:786-800.

(77) Horwitz DA, Zheng SG, Gray JD. Natural and TGF-beta-induced FoxP3(+)CD4(+) CD25(+) regulatory $\mathrm{T}$ cells are not mirror images of each other. Trends Immunol 2008;29:429-35.

(78) Polansky JK, Kretschmer K, Freyer J, Floess S, Garbe A, Baron U, et al. DNA methylation controls FoxP3 gene expression. Eur J Immunol 2008;38:1654-63.

(79) Floess S, Freyer J, Siewert C, Baron U, Olek S, Polansky J, et al. Epigenetic control of the FoxP3 locus in regulatory T cells. PLoS Biol 2007;5:e38.

(80) Huehn J, Polansky JK, Hamann A. Epigenetic control of FOXP3 expression: the key to a stable regulatory T-cell lineage? Nat Rev Immunol 2009;9:83-9.

(81) Cobbold SP, Castejon R, Adams E, Zelenika D, Graca L, Humm S, et al. Induction of FoxP3+ regulatory $\mathrm{T}$ cells in the periphery of $\mathrm{T}$ cell receptor transgenic mice tolerized to transplants. J Immunol 2004;172:6003-10.

(82) Curotto de Lafaille MA, Kutchukhidze N, Shen S, Ding Y, Yee H, Lafaille JJ. Adaptive FoxP3+ regulatory $\mathrm{T}$ cell-dependent and -independent control of allergic inflammation. Immunity 2008;29:114-26.

(83) Mucida D, Kutchukhidze N, Erazo A, Russo M, Lafaille JJ, Curotto de Lafaille MA. Oral tolerance in the absence of naturally occurring Tregs. J Clin Invest 2005;115:1923-33.

(84) Nakamura K, Kitani A, Strober W. Cell contact-dependent immunosuppression by $\mathrm{CD} 4(+) \mathrm{CD} 25(+)$ regulatory $\mathrm{T}$ cells is mediated by cell surface-bound transforming growth factor beta. J Exp Med 2001;194:629-44.

(85) Kingsley CI, Karim M, Bushell AR, Wood KJ. CD25+CD4+ regulatory T cells prevent graft rejection: CTLA-4- and IL-10-dependent immunoregulation of alloresponses. J Immunol 2002;168:1080-6.

(86) Shevach EM. CD4+ CD25+ suppressor T cells: more questions than answers. Nat Rev Immunol 2002;2:389-400. 
(87) Mueller N. Overview of the epidemiology of malignancy in immune deficiency. J Acquir Immune Defic Syndr 1999;21 Suppl 1:S5-10.

(88) Eyles J, Puaux AL, Wang X, Toh B, Prakash C, Hong M, et al. Tumor cells disseminate early, but immunosurveillance limits metastatic outgrowth, in a mouse model of melanoma. J Clin Invest 2010;120:2030-9.

(89) Lee PP, Yee C, Savage PA, Fong L, Brockstedt D, Weber JS, et al. Characterization of circulating $T$ cells specific for tumor-associated antigens in melanoma patients. Nat Med 1999;5:677-85.

(90) Blank C, Gajewski TF, Mackensen A. Interaction of PD-Ll on tumor cells with PD-1 on tumor-specific $T$ cells as a mechanism of immune evasion: implications for tumor immunotherapy. Cancer Immunol Immunother 2005;54:307-14.

(91) Drake CG, Jaffee E, Pardoll DM. Mechanisms of immune evasion by tumors. Adv Immunol 2006;90:51-81.

(92) Khong HT, Restifo NP. Natural selection of tumor variants in the generation of "tumor escape" phenotypes. Nat Immunol 2002;3:999-1005.

(93) Li MO, Sanjabi S, Flavell RA. Transforming growth factor-beta controls development, homeostasis, and tolerance of $\mathrm{T}$ cells by regulatory $\mathrm{T}$ celldependent and -independent mechanisms. Immunity 2006;25:455-71.

(94) Liyanage UK, Moore TT, Joo HG, Tanaka Y, Herrmann V, Doherty G, et al. Prevalence of regulatory $\mathrm{T}$ cells is increased in peripheral blood and tumor microenvironment of patients with pancreas or breast adenocarcinoma. J Immunol 2002;169:2756-61.

(95) Viguier M, Lemaitre F, Verola O, Cho MS, Gorochov G, Dubertret L, et al. FoxP3 expressing $\mathrm{CD} 4+\mathrm{CD} 25$ (high) regulatory $\mathrm{T}$ cells are overrepresented in human metastatic melanoma lymph nodes and inhibit the function of infiltrating $\mathrm{T}$ cells. J Immunol 2004;173:1444-53.

(96) Elpek KG, Lacelle C, Singh NP, Yolcu ES, Shirwan H. CD4+CD25+ T regulatory cells dominate multiple immune evasion mechanisms in early but not late phases of tumor development in a B cell lymphoma model. J Immunol 2007;178:6840-8.

(97) Knutson KL, Dang Y, Lu H, Lukas J, Almand B, Gad E, et al. IL-2 immunotoxin therapy modulates tumor-associated regulatory $\mathrm{T}$ cells and leads to lasting immune-mediated rejection of breast cancers in neu-transgenic mice. J Immunol 2006;177:84-91.

(98) Ko K, Yamazaki S, Nakamura K, Nishioka T, Hirota K, Yamaguchi T, et al. Treatment of advanced tumors with agonistic anti-GITR mAb and its effects on tumor-infiltrating FoxP3+CD25+CD4+ regulatory $\mathrm{T}$ cells. J Exp Med 2005;202:885-91. 
(99) Chambers CA, Kuhns MS, Egen JG, Allison JP. CTLA-4-mediated inhibition in regulation of $\mathrm{T}$ cell responses: mechanisms and manipulation in tumor immunotherapy. Annu Rev Immunol 2001;19:565-94.

(100) Rabinovich GA, Gabrilovich D, Sotomayor EM. Immunosuppressive strategies that are mediated by tumor cells. Annu Rev Immunol 2007;25:267-96.

(101) von BH. Mechanisms of suppression by suppressor $T$ cells. Nat Immunol 2005;6:338-44.

(102) Zou W. Regulatory T cells, tumour immunity and immunotherapy. Nat Rev Immunol 2006;6:295-307.

(103) Liu VC, Wong LY, Jang T, Shah AH, Park I, Yang X, et al. Tumor evasion of the immune system by converting CD4+. J Immunol 2007;178:2883-92.

(104) Sutmuller RP, van Duivenvoorde LM, van EA, Schumacher TN, Wildenberg ME, Allison JP, et al. Synergism of cytotoxic T lymphocyte-associated antigen 4 blockade and depletion of $\mathrm{CD} 25(+)$ regulatory $\mathrm{T}$ cells in antitumor therapy reveals alternative pathways for suppression of autoreactive cytotoxic $\mathrm{T}$ lymphocyte responses. J Exp Med 2001;194:823-32.

(105) Sharma S, Yang SC, Zhu L, Reckamp K, Gardner B, Baratelli F, et al. Tumor cyclooxygenase-2/prostaglandin E2-dependent promotion of FOXP3 expression and $\mathrm{CD} 4+\mathrm{CD} 25+\mathrm{T}$ regulatory cell activities in lung cancer. Cancer Res 2005;65:5211-20.

(106) Welniak LA, Blazar BR, Murphy WJ. Immunobiology of allogeneic hematopoietic stem cell transplantation. Annu Rev Immunol 2007;25:139-70.

(107) Vallera DA, Taylor PA, Sprent J, Blazar BR. The role of host T cell subsets in bone marrow rejection directed to isolated major histocompatibility complex class I versus class II differences of $\mathrm{bml}$ and $\mathrm{bm} 12$ mutant mice. Transplantation $1994 ; 57: 249-56$.

(108) Cudkowicz G, Bennett M. Peculiar immunobiology of bone marrow allografts. I. Graft rejection by irradiated responder mice. J Exp Med 1971;134:83-102.

(109) Haraguchi K, Takahashi T, Matsumoto A, Asai T, Kanda Y, Kurokawa M, et al. Host-residual invariant NK $\mathrm{T}$ cells attenuate graft-versus-host immunity. J Immunol 2005;175:1320-8.

(110) Blazar BR, Taylor PA, Bluestone JA, Vallera DA. Murine gamma/deltaexpressing $\mathrm{T}$ cells affect alloengraftment via the recognition of nonclassical major histocompatibility complex class Ib antigens. Blood 1996;87:4463-72.

(111) Drobyski WR, Majewski D. Donor gamma delta $T$ lymphocytes promote allogeneic engraftment across the major histocompatibility barrier in mice. Blood 1997;89:1100-9. 
(112) Braun MY, Lowin B, French L, Acha-Orbea H, Tschopp J. Cytotoxic T cells deficient in both functional fas ligand and perforin show residual cytolytic activity yet lose their capacity to induce lethal acute graft-versus-host disease. J Exp Med 1996;183:657-61.

(113) Deeg HJ, Storb R, Shulman HM, Weiden PL, Graham TC, Thomas ED. Engraftment of DLA-nonidentical unrelated canine marrow after high-dose fractionated total body irradiation. Transplantation 1982;33:443-6.

(114) Martino R, Iacobelli S, Brand R, Jansen T, van BA, Finke J, et al. Retrospective comparison of reduced-intensity conditioning and conventional high-dose conditioning for allogeneic hematopoietic stem cell transplantation using HLAidentical sibling donors in myelodysplastic syndromes. Blood 2006;108:836-46.

(115) Shevach EM, DiPaolo RA, Andersson J, Zhao DM, Stephens GL, Thornton AM. The lifestyle of naturally occurring $\mathrm{CD} 4+\mathrm{CD} 25+$ FoxP3 + regulatory $\mathrm{T}$ cells. Immunol Rev 2006;212:60-73.

(116) Gavin M, Rudensky A. Control of immune homeostasis by naturally arising regulatory CD4+ T cells. Curr Opin Immunol 2003;15:690-6.

(117) June $\mathrm{CH}$, Blazar BR. Clinical application of expanded CD4+25+ cells. Semin Immunol 2006;18:78-88.

(118) Cohen JL, Trenado A, Vasey D, Klatzmann D, Salomon BL. CD4 $(+)$ CD25(+) immunoregulatory $\mathrm{T}$ Cells: new therapeutics for graft-versus-host disease. J Exp Med 2002;196:401-6.

(119) Taylor PA, Lees CJ, Blazar BR. The infusion of ex vivo activated and expanded $\mathrm{CD} 4(+) \mathrm{CD} 25(+)$ immune regulatory cells inhibits graft-versus-host disease lethality. Blood 2002;99:3493-9.

(120) Gao W, Lu Y, El EB, Oukka M, Kuchroo VK, Strom TB. Contrasting effects of cyclosporine and rapamycin in de novo generation of alloantigen-specific regulatory T cells. Am J Transplant 2007;7:1722-32.

(121) Wullschleger S, Loewith R, Hall MN. TOR signaling in growth and metabolism. Cell 2006;124:471-84.

(122) Vezina C, Kudelski A, Sehgal SN. Rapamycin (AY-22,989), a new antifungal antibiotic. I. Taxonomy of the producing streptomycete and isolation of the active principle. J Antibiot (Tokyo) 1975;28:721-6.

(123) Saunders RN, Metcalfe MS, Nicholson ML. Rapamycin in transplantation: a review of the evidence. Kidney Int 2001;59:3-16.

(124) Armand P, Gannamaneni S, Kim HT, Cutler CS, Ho VT, Koreth J, et al. Improved survival in lymphoma patients receiving sirolimus for graft-versus-host 
disease prophylaxis after allogeneic hematopoietic stem-cell transplantation with reduced-intensity conditioning. J Clin Oncol 2008;26:5767-74.

(125) Eisen HJ, Tuzcu EM, Dorent R, Kobashigawa J, Mancini D, Valantine-von Kaeppler HA, et al. Everolimus for the prevention of allograft rejection and vasculopathy in cardiac-transplant recipients. N Engl J Med 2003;349:847-58.

(126) Sabatini DM. mTOR and cancer: insights into a complex relationship. Nat Rev Cancer 2006;6:729-34.

(127) Coenen JJ, Koenen HJ, van RE, Kasran A, Boon L, Hilbrands LB, et al. Rapamycin, not cyclosporine, permits thymic generation and peripheral preservation of $\mathrm{CD} 4+\mathrm{CD} 25+$ FoxP3 $+\mathrm{T}$ cells. Bone Marrow Transplant 2007;39:537-45.

(128) Battaglia M, Stabilini A, Migliavacca B, Horejs-Hoeck J, Kaupper T, Roncarolo MG. Rapamycin promotes expansion of functional $\mathrm{CD} 4+\mathrm{CD} 25+\mathrm{FOXP} 3+$ regulatory $\mathrm{T}$ cells of both healthy subjects and type 1 diabetic patients. J Immunol 2006;177:8338-47.

(129) Noris M, Casiraghi F, Todeschini M, Cravedi P, Cugini D, Monteferrante G, et al. Regulatory $\mathrm{T}$ cells and $\mathrm{T}$ cell depletion: role of immunosuppressive drugs. J Am Soc Nephrol 2007;18:1007-18.

(130) Battaglia M, Stabilini A, Roncarolo MG. Rapamycin selectively expands CD4+CD25+FoxP3+ regulatory T cells. Blood 2005;105:4743-8.

(131) Valmori D, Tosello V, Souleimanian NE, Godefroy E, Scotto L, Wang Y, et al. Rapamycin-mediated enrichment of $\mathrm{T}$ cells with regulatory activity in stimulated $\mathrm{CD} 4+\mathrm{T}$ cell cultures is not due to the selective expansion of naturally occurring regulatory $\mathrm{T}$ cells but to the induction of regulatory functions in conventional CD4+ T cells. J Immunol 2006;177:944-9.

(132) Tone Y, Furuuchi K, Kojima Y, Tykocinski ML, Greene MI, Tone M. Smad3 and NFAT cooperate to induce FoxP3 expression through its enhancer. Nat Immunol 2008;9:194-202.

(133) Song K, Wang H, Krebs TL, Danielpour D. Novel roles of Akt and mTOR in suppressing TGF-beta/ALK5-mediated Smad3 activation. EMBO J 2006;25:5869.

(134) Fischer R, Turnquist HR, Taner T, Thomson AW. Use of rapamycin in the induction of tolerogenic dendritic cells. Handb Exp Pharmacol 2009;215-32.

(135) Lenschow DJ, Walunas TL, Bluestone JA. CD28/B7 system of T cell costimulation. Annu Rev Immunol 1996;14:233-58.

(136) Watts TH. TNF/TNFR family members in costimulation of T cell responses. Annu Rev Immunol 2005;23:23-68. 
(137) Sprent J, Surh CD. T cell memory. Annu Rev Immunol 2002;20:551-79.

(138) Dempsey PW, Doyle SE, He JQ, Cheng G. The signaling adaptors and pathways activated by TNF superfamily. Cytokine Growth Factor Rev 2003;14:193-209.

(139) Locksley RM, Killeen N, Lenardo MJ. The TNF and TNF receptor superfamilies: integrating mammalian biology. Cell 2001;104:487-501.

(140) Cannons JL, Lau P, Ghumman B, DeBenedette MA, Yagita H, Okumura K, et al. 4-1BB ligand induces cell division, sustains survival, and enhances effector function of $\mathrm{CD} 4$ and $\mathrm{CD} 8 \mathrm{~T}$ cells with similar efficacy. J Immunol 2001;167:1313-24.

(141) Alderson MR, Smith CA, Tough TW, Davis-Smith T, Armitage RJ, Falk B, et al. Molecular and biological characterization of human 4-1BB and its ligand. Eur J Immunol 1994;24:2219-27.

(142) Goodwin RG, Din WS, Davis-Smith T, Anderson DM, Gimpel SD, Sato TA, et al. Molecular cloning of a ligand for the inducible T cell gene 4-1BB: a member of an emerging family of cytokines with homology to tumor necrosis factor. Eur J Immunol 1993;23:2631-41.

(143) Futagawa $T$, Akiba H, Kodama T, Takeda K, Hosoda Y, Yagita H, et al. Expression and function of 4-1BB and 4-1BB ligand on murine dendritic cells. Int Immunol 2002;14:275-86.

(144) Heinisch IV, Bizer C, Volgger W, Simon HU. Functional CD137 receptors are expressed by eosinophils from patients with IgE-mediated allergic responses but not by eosinophils from patients with non-IgE-mediated eosinophilic disorders. J Allergy Clin Immunol 2001;108:21-8.

(145) Kienzle G, von KJ. CD137 (ILA/4-1BB), expressed by primary human monocytes, induces monocyte activation and apoptosis of $\mathrm{B}$ lymphocytes. Int Immunol 2000;12:73-82.

(146) Pauly S, Broll K, Wittmann M, Giegerich G, Schwarz H. CD137 is expressed by follicular dendritic cells and costimulates $\mathrm{B}$ lymphocyte activation in germinal centers. J Leukoc Biol 2002;72:35-42.

(147) Wilcox RA, Tamada K, Strome SE, Chen L. Signaling through NK cellassociated CD137 promotes both helper function for CD8+ cytolytic T cells and responsiveness to IL-2 but not cytolytic activity. J Immunol 2002;169:4230-6.

(148) Diehl L, van Mierlo GJ, den Boer AT, van d, V, Fransen M, van BL, et al. In vivo triggering through 4-1BB enables Th-independent priming of CTL in the presence of an intact CD28 costimulatory pathway. J Immunol 2002;168:3755-62.

(149) Laderach D, Wesa A, Galy A. 4-1BB-ligand is regulated on human dendritic cells and induces the production of IL-12. Cell Immunol 2003;226:37-44. 
(150) Croft M. The role of TNF superfamily members in T-cell function and diseases. Nat Rev Immunol 2009;9:271-85.

(151) Langstein J, Michel J, Fritsche J, Kreutz M, Andreesen R, Schwarz H. CD137 (ILA/4-1BB), a member of the TNF receptor family, induces monocyte activation via bidirectional signaling. J Immunol 1998;160:2488-94.

(152) Pollok KE, Kim YJ, Hurtado J, Zhou Z, Kim KK, Kwon BS. 4-1BB T-cell antigen binds to mature $\mathrm{B}$ cells and macrophages, and costimulates anti-muprimed splenic B cells. Eur J Immunol 1994;24:367-74.

(153) Lippert U, Zachmann K, Ferrari DM, Schwarz H, Brunner E, Mahbub-Ul Latif $\mathrm{AH}$, et al. CD137 ligand reverse signaling has multiple functions in human dendritic cells during an adaptive immune response. Eur $\mathrm{J}$ Immunol 2008;38:1024-32.

(154) Ju S, Ju S, Ge Y, Qiu H, Lu B, Qiu Y, et al. A novel approach to induce human DCs from monocytes by triggering $4-1 \mathrm{BBL}$ reverse signaling. Int Immunol 2009;21:1135-44.

(155) Gramaglia I, Cooper D, Miner KT, Kwon BS, Croft M. Co-stimulation of antigen-specific CD4 T cells by 4-1BB ligand. Eur J Immunol 2000;30:392-402.

(156) Vinay DS, Kwon BS. Role of 4-1BB in immune responses. Semin Immunol 1998;10:481-9.

(157) Takahashi C, Mittler RS, Vella AT. Cutting edge: 4-1BB is a bona fide CD8 T cell survival signal. J Immunol 1999;162:5037-40.

(158) Dawicki W, Watts TH. Expression and function of 4-1BB during CD4 versus CD8 T cell responses in vivo. Eur J Immunol 2004;34:743-51.

(159) Choi BK, Bae JS, Choi EM, Kang WJ, Sakaguchi S, Vinay DS, et al. 4-1BBdependent inhibition of immunosuppression by activated CD4+CD25+ T cells. J Leukoc Biol 2004;75:785-91.

(160) McHugh RS, Whitters MJ, Piccirillo CA, Young DA, Shevach EM, Collins M, et al. $\mathrm{CD} 4(+) \mathrm{CD} 25(+)$ immunoregulatory $\mathrm{T}$ cells: gene expression analysis reveals a functional role for the glucocorticoid-induced TNF receptor. Immunity $2002 ; 16: 311-23$.

(161) Wen T, Bukczynski J, Watts TH. 4-1BB ligand-mediated costimulation of human $\mathrm{T}$ cells induces CD4 and CD8 T cell expansion, cytokine production, and the development of cytolytic effector function. J Immunol 2002;168:4897-906.

(162) Zhang P, Gao F, Wang Q, Wang X, Zhu F, Ma C, et al. Agonistic anti-4-1BB antibody promotes the expansion of natural regulatory $\mathrm{T}$ cells while maintaining FoxP3 expression. Scand J Immunol 2007;66:435-40. 
(163) Woo EY, Chu CS, Goletz TJ, Schlienger K, Yeh H, Coukos G, et al. Regulatory $\mathrm{CD} 4(+) \mathrm{CD} 25(+) \mathrm{T}$ cells in tumors from patients with early-stage non-small cell lung cancer and late-stage ovarian cancer. Cancer Res 2001;61:4766-72.

(164) Curiel TJ, Coukos G, Zou L, Alvarez X, Cheng P, Mottram P, et al. Specific recruitment of regulatory $T$ cells in ovarian carcinoma fosters immune privilege and predicts reduced survival. Nat Med 2004;10:942-9.

(165) Apostolou I, von BH. In vivo instruction of suppressor commitment in naive T cells. J Exp Med 2004;199:1401-8.

(166) Chen W, Jin W, Hardegen N, Lei KJ, Li L, Marinos N, et al. Conversion of peripheral CD4+. J Exp Med 2003;198:1875-86.

(167) Kretschmer K, Apostolou I, Hawiger D, Khazaie K, Nussenzweig MC, von BH. Inducing and expanding regulatory $\mathrm{T}$ cell populations by foreign antigen. Nat Immunol 2005;6:1219-27.

(168) Valzasina B, Piconese S, Guiducci C, Colombo MP. Tumor-induced expansion of regulatory $\mathrm{T}$ cells by conversion of $\mathrm{CD} 4+\mathrm{CD} 25-$ lymphocytes is thymus and proliferation independent. Cancer Res 2006;66:4488-95.

(169) Smyth MJ, Teng MW, Swann J, Kyparissoudis K, Godfrey DI, Hayakawa Y. CD4+CD25+ T regulatory cells suppress NK cell-mediated immunotherapy of cancer. J Immunol 2006;176:1582-7.

(170) Yang ZZ, Novak AJ, Stenson MJ, Witzig TE, Ansell SM. Intratumoral $\mathrm{CD} 4+\mathrm{CD} 25+$ regulatory $\mathrm{T}$-cell-mediated suppression of infiltrating $\mathrm{CD} 4+\mathrm{T}$ cells in B-cell non-Hodgkin lymphoma. Blood 2006;107:3639-46.

(171) Chen W, Zhou D, Torrealba JR, Waddell TK, Grant D, Zhang L. Donor lymphocyte infusion induces long-term donor-specific cardiac xenograft survival through activation of recipient double-negative regulatory $\mathrm{T}$ cells. J Immunol 2005;175:3409-16.

(172) Campbell DJ, Ziegler SF. FOXP3 modifies the phenotypic and functional properties of regulatory T cells. Nat Rev Immunol 2007;7:305-10.

(173) Shevach EM. From vanilla to 28 flavors: multiple varieties of T regulatory cells. Immunity 2006;25:195-201.

(174) Marie JC, Liggitt D, Rudensky AY. Cellular mechanisms of fatal early-onset autoimmunity in mice with the $\mathrm{T}$ cell-specific targeting of transforming growth factor-beta receptor. Immunity 2006;25:441-54.

(175) Coombes JL, Siddiqui KR, Arancibia-Carcamo CV, Hall J, Sun CM, Belkaid Y, et al. A functionally specialized population of mucosal CD103+ DCs induces FoxP3 + regulatory $\mathrm{T}$ cells via a TGF-beta and retinoic acid-dependent mechanism. J Exp Med 2007;204:1757-64. 
(176) Valzasina B, Piconese S, Guiducci C, Colombo MP. Tumor-induced expansion of regulatory $\mathrm{T}$ cells by conversion of $\mathrm{CD} 4+\mathrm{CD} 25-$ lymphocytes is thymus and proliferation independent. Cancer Res 2006;66:4488-95.

(177) Grossman WJ, Verbsky JW, Barchet W, Colonna M, Atkinson JP, Ley TJ. Human $T$ regulatory cells can use the perforin pathway to cause autologous target cell death. Immunity 2004;21:589-601.

(178) Thornton AM, Shevach EM. CD4+CD25+ immunoregulatory $\mathrm{T}$ cells suppress polyclonal $\mathrm{T}$ cell activation in vitro by inhibiting interleukin 2 production. J Exp Med 1998;188:287-96.

(179) Mellor AL, Munn DH. IDO expression by dendritic cells: tolerance and tryptophan catabolism. Nat Rev Immunol 2004;4:762-74.

(180) Asseman C, Mauze S, Leach MW, Coffman RL, Powrie F. An essential role for interleukin 10 in the function of regulatory $T$ cells that inhibit intestinal inflammation. J Exp Med 1999;190:995-1004.

(181) Cannons JL, Lau P, Ghumman B, DeBenedette MA, Yagita H, Okumura K, et al. 4-1BB ligand induces cell division, sustains survival, and enhances effector function of $\mathrm{CD} 4$ and $\mathrm{CD} 8 \mathrm{~T}$ cells with similar efficacy. J Immunol 2001;167:1313-24.

(182) Kwon BS, Weissman SM. cDNA sequences of two inducible T-cell genes. Proc Natl Acad Sci U S A 1989;86:1963-7.

(183) Pollok KE, Kim YJ, Zhou Z, Hurtado J, Kim KK, Pickard RT, et al. Inducible T cell antigen 4-1BB. Analysis of expression and function. $J$ Immunol $1993 ; 150: 771-81$.

(184) Sharma RK, Elpek KG, Yolcu ES, Schabowsky RH, Zhao H, Bandura-Morgan L, et al. Costimulation as a platform for the development of vaccines: a peptidebased vaccine containing a novel form of 4-1BB ligand eradicates established tumors. Cancer Res 2009;69:4319-26.

(185) Elpek KG, Yolcu ES, Franke DD, Lacelle C, Schabowsky RH, Shirwan H. Ex vivo expansion of $\mathrm{CD} 4+\mathrm{CD} 25+\mathrm{FoxP} 3+\mathrm{T}$ regulatory cells based on synergy between IL-2 and 4-1BB signaling. J Immunol 2007;179:7295-304.

(186) Kusser KL, Randall TD. Simultaneous detection of EGFP and cell surface markers by fluorescence microscopy in lymphoid tissues. J Histochem Cytochem 2003;51:5-14.

(187) So T, Croft M. Cutting edge: OX40 inhibits TGF-beta- and antigen-driven conversion of naive CD4 $\mathrm{T}$ cells into $\mathrm{CD} 25+\mathrm{FoxP} 3+\mathrm{T}$ cells. J Immunol 2007;179:1427-30. 
(188) Wu Y, Borde M, Heissmeyer V, Feuerer M, Lapan AD, Stroud JC, et al. FOXP3 controls regulatory $\mathrm{T}$ cell function through cooperation with NFAT. Cell $2006 ; 126: 375-87$.

(189) Marson A, Kretschmer K, Frampton GM, Jacobsen ES, Polansky JK, MacIsaac $\mathrm{KD}$, et al. FoxP3 occupancy and regulation of key target genes during T-cell stimulation. Nature 2007;445:931-5.

(190) Ruby CE, Yates MA, Hirschhorn-Cymerman D, Chlebeck P, Wolchok JD, Houghton $\mathrm{AN}$, et al. Cutting Edge: $\mathrm{OX} 40$ agonists can drive regulatory $\mathrm{T}$ cell expansion if the cytokine milieu is right. J Immunol 2009;183:4853-7.

(191) Xiao X, Kroemer A, Gao W, Ishii N, Demirci G, Li XC. OX40/OX40L costimulation affects induction of FoxP $3+$ regulatory $\mathrm{T}$ cells in part by expanding memory T cells in vivo. J Immunol 2008;181:3193-201.

(192) Xiao X, Kroemer A, Gao W, Ishii N, Demirci G, Li XC. OX40/OX40L costimulation affects induction of FoxP $3+$ regulatory $\mathrm{T}$ cells in part by expanding memory T cells in vivo. J Immunol 2008;181:3193-201.

(193) Liyanage UK, Moore TT, Joo HG, Tanaka Y, Herrmann V, Doherty G, et al. Prevalence of regulatory $\mathrm{T}$ cells is increased in peripheral blood and tumor microenvironment of patients with pancreas or breast adenocarcinoma. J Immunol 2002;169:2756-61.

(194) Zou W. Regulatory T cells, tumour immunity and immunotherapy. Nat Rev Immunol 2006;6:295-307.

(195) Liu VC, Wong LY, Jang T, Shah AH, Park I, Yang X, et al. Tumor evasion of the immune system by converting CD4+. J Immunol 2007;178:2883-92.

(196) Sharma RK, Schabowsky RH, Srivastava AK, Elpek KG, Madireddi S, Zhao H, et al. 4-1BB ligand as an effective multifunctional immunomodulator and antigen delivery vehicle for the development of therapeutic cancer vaccines. Cancer Res 2010;70:3945-54.

(197) Pauly S, Broll K, Wittmann M, Giegerich G, Schwarz H. CD137 is expressed by follicular dendritic cells and costimulates $\mathrm{B}$ lymphocyte activation in germinal centers. J Leukoc Biol 2002;72:35-42.

(198) Wilcox RA, Tamada K, Strome SE, Chen L. Signaling through NK cellassociated CD137 promotes both helper function for CD8+ cytolytic T cells and responsiveness to IL-2 but not cytolytic activity. J Immunol 2002;169:4230-6.

(199) Zhang P, Gao F, Wang Q, Wang X, Zhu F, Ma C, et al. Agonistic anti-4-1BB antibody promotes the expansion of natural regulatory $\mathrm{T}$ cells while maintaining FoxP3 expression. Scand J Immunol 2007;66:435-40. 
(200) Zheng G, Wang B, Chen A. The 4-1BB costimulation augments the proliferation of CD4+CD25+ regulatory T cells. J Immunol 2004;173:2428-34.

(201) Valzasina B, Guiducci C, Dislich H, Killeen N, Weinberg AD, Colombo MP. Triggering of $\mathrm{OX} 40(\mathrm{CD} 134)$ on $\mathrm{CD} 4(+) \mathrm{CD} 25+\mathrm{T}$ cells blocks their inhibitory activity: a novel regulatory role for OX40 and its comparison with GITR. Blood 2005;105:2845-51.

(202) Vu MD, Xiao X, Gao W, Degauque N, Chen M, Kroemer A, et al. OX40 costimulation turns off FoxP3+ Tregs. Blood 2007;110:2501-10.

(203) Duan W, So T, Croft M. Antagonism of airway tolerance by endotoxin/lipopolysaccharide through promoting OX40L and suppressing antigen-specific FoxP3 + T regulatory cells. J Immunol 2008;181:8650-9.

(204) Dawicki W, Bertram EM, Sharpe AH, Watts TH. 4-1BB and OX40 act independently to facilitate robust CD8 and CD4 recall responses. J Immunol 2004;173:5944-51.

(205) So T, Lee SW, Croft M. Immune regulation and control of regulatory $\mathrm{T}$ cells by OX40 and 4-1BB. Cytokine Growth Factor Rev 2008;19:253-62.

(206) Wei J, Duramad O, Perng OA, Reiner SL, Liu YJ, Qin FX. Antagonistic nature of T helper 1/2 developmental programs in opposing peripheral induction of FoxP3+ regulatory T cells. Proc Natl Acad Sci U S A 2007;104:18169-74.

(207) Marie JC, Letterio JJ, Gavin M, Rudensky AY. TGF-beta1 maintains suppressor function and FoxP3 expression in CD4+CD25+ regulatory T cells. J Exp Med 2005;201:1061-7.

(208) Kim HP, Leonard WJ. CREB/ATF-dependent $\mathrm{T}$ cell receptor-induced FoxP3 gene expression: a role for DNA methylation. J Exp Med 2007;204:1543-51.

(209) Zheng G, Wang B, Chen A. The 4-1BB costimulation augments the proliferation of CD4+CD25+ regulatory T cells. J Immunol 2004;173:2428-34.

(210) Shirwan H. Chronic allograft rejection. Do the Th2 cells preferentially induced by indirect alloantigen recognition play a dominant role? Transplantation 1999;68:715-26.

(211) Luo H, Duguid W, Chen H, Maheu M, Wu J. The effect of rapamycin on T cell development in mice. Eur J Immunol 1994;24:692-701.

(212) Damoiseaux JG, Defresne MP, Reutelingsperger CP, Van Breda Vriesman PJ. Cyclosporin-A differentially affects apoptosis during in vivo rat thymocyte maturation. Scand J Immunol 2002;56:353-60.

(213) Haxhinasto S, Mathis D, Benoist C. The AKT-mTOR axis regulates de novo differentiation of CD4+FoxP3+ cells. J Exp Med 2008;205:565-74. 
(214) Coenen JJ, Koenen HJ, van RE, Hilbrands LB, Joosten I. Rapamycin, and not cyclosporin A, preserves the highly suppressive $\mathrm{CD} 27+$ subset of human CD4+CD25+ regulatory T cells. Blood 2006;107:1018-23.

(215) Zeiser R, Nguyen VH, Beilhack A, Buess M, Schulz S, Baker J, et al. Inhibition of CD4+CD25+ regulatory T-cell function by calcineurin-dependent interleukin-2 production. Blood 2006;108:390-9.

(216) Segundo DS, Ruiz JC, Izquierdo M, Fernandez-Fresnedo G, Gomez-Alamillo C, Merino R, et al. Calcineurin inhibitors, but not rapamycin, reduce percentages of $\mathrm{CD} 4+\mathrm{CD} 25+\mathrm{FOXP} 3+$ regulatory $\mathrm{T}$ cells in renal transplant recipients. Transplantation 2006;82:550-7.

(217) Kretschmer K, Apostolou I, Jaeckel E, Khazaie K, von BH. Making regulatory T cells with defined antigen specificity: role in autoimmunity and cancer. Immunol Rev 2006;212:163-9.

(218) Uppaluri R, Sheehan KC, Wang L, Bui JD, Brotman JJ, Lu B, et al. Prolongation of cardiac and islet allograft survival by a blocking hamster anti-mouse CXCR3 monoclonal antibody. Transplantation 2008;86:137-47.

(219) Strauss L, Whiteside TL, Knights A, Bergmann C, Knuth A, Zippelius A. Selective survival of naturally occurring human $\mathrm{CD} 4+\mathrm{CD} 25+\mathrm{FoxP} 3+$ regulatory T cells cultured with rapamycin. J Immunol 2007;178:320-9.

(220) Chen JF, Gao J, Zhang D, Wang ZH, Zhu JY. CD4+FoxP3+ regulatory T cells converted by rapamycin from peripheral $\mathrm{CD} 4+\mathrm{CD} 25(-)$ naive $\mathrm{T}$ cells display more potent regulatory ability in vitro. Chin Med J (Engl ) 2010;123:942-8.

(221) Zeiser R, Leveson-Gower DB, Zambricki EA, Kambham N, Beilhack A, Loh J, et al. Differential impact of mammalian target of rapamycin inhibition on CD4+CD25+FoxP3+ regulatory $\mathrm{T}$ cells compared with conventional CD4+ $\mathrm{T}$ cells. Blood 2008;111:453-62.

(222) Burchill MA, Yang J, Vogtenhuber C, Blazar BR, Farrar MA. IL-2 receptor betadependent STAT5 activation is required for the development of FoxP3+ regulatory T cells. J Immunol 2007;178:280-90.

(223) Earle KE, Tang Q, Zhou X, Liu W, Zhu S, Bonyhadi ML, et al. In vitro expanded human $\mathrm{CD} 4+\mathrm{CD} 25+$ regulatory $\mathrm{T}$ cells suppress effector $\mathrm{T}$ cell proliferation. Clin Immunol 2005;115:3-9.

(224) Thomson AW, Turnquist HR, Raimondi G. Immunoregulatory functions of mTOR inhibition. Nat Rev Immunol 2009;9:324-37. 


\section{CURRICULUM VITAE Shravan Madireddi}

\section{PROFILE}

Business Address:

Home Address:

Place of Birth:

Citizenship:

Visa Status:

Maritial Status:

Date of Birth:

\section{EDUCATION:}

$\underline{\text { Institution }}$

Osmania University, India

APTECH Ltd, India

SRTMU University, India

University of Louisville

University of Louisville, KY
Institute of Cellular Therapeutics

Department of Microbiology and Immunology

University of Louisville

570 South Preston St., Suite 404

Louisville, KY 40202

Phone: (502) 852-2065 (work), (502) 526-8215 (mobile)

Fax: (502) 852-2085

Email: skredd01@louisville.edu, mad reddi@yahoo.com

3000 Ledgebrook ct

Louisville, KY 40241

Phone: (502) 212-4386

Mahabubnagar, A.P., India

India

F1

Married

08-02-1980

\section{$\underline{\text { Degree }}$}

BS

Diploma

MS

MS

Ph.D $\underline{\text { Major }}$

$\underline{\text { Dates }}$

Life Sciences

$1997-2000$

$2000-2001$

$2001-2003$

$2005-2007$

Biotechnology

Immunology

Immunology 


\section{RESEARCH EXPERIENCE:}

University of Louisville, Louisville, KY

Advisor: Dr. Haval Shirwan

Ph.D research

Project: Examining the effect of 4-1BB/4-1BBL costimulation on conversion of naive CD4 T cells into FoxP3 expressing T cells.

- Result: Able to show that SA-4-1BBL costimulation inhibits conversion of naïve $\mathrm{CD}^{+} \mathrm{T}$ cells into $\mathrm{CD} 4^{+} \mathrm{CD} 25^{+} \mathrm{FoxP} 3^{+} \mathrm{T}$ regulatory cells by production of IFN- $\gamma$.

- Article has been submitted to Cancer Research

\section{TEACHING EXPERIENCE:}

- Teaching assistant, Department of Biotechnology, SRTM University, Nanded, India. 2002-2003

\section{AWARDS AND HONORS:}

- Received University $2^{\text {nd }}$ rank in all MS. Biotechnology examination at Yeshwant Mahavidyalaya, SRTM University, Nanded, India 2003

- Received CSIR-UGC-NET-Junior lectureship in India. 2004

- Integrated Program for Biomedical Sciences (IPIBS) fellowship, University of Louisville, Louisville, KY. 2005-2007

\section{PUBLICATIONS:}

1. Schabowsky RH, Elpek KG, Madireddi S, Sharma RK, Yolcu ES, BanduraMorgan L, Miller R, MacLeod KJ, Mittler RS and Shirwan H. A novel form of 41BBL has better immunomodulatory activity than an agonistic anti-4-1BB Ab without $A b$-associated severe toxicity. Vaccine. 28:512-22, 2009.

2. Sharma RK, Schabowsky RH, Srivastava A, Elpek KG, Madireddi S, Yolcu ES and Shirwan H. A 4-1BBL conjugated vaccine delivers tumor associated antigen in dendritic cells for elicitation of robust antitumor response eradicates established tumors. Cancer Research. 70:3945-54, 2010.

3. Sharma RK, Srivastava A, Yolcu ES, Kathryn JM, Schabowsky RH, Madireddi S and Shirwan H. SA-4-1BBL as the immunomodulatory component of a HPV-16 E7 protein based vaccine shows robust therapeutic efficacy in a mouse cervical cancer model. Vaccine, In Press 


\section{Manuscripts submitted:}

1. Yolcu ES, Zhao H, Bandura-Morgan L, Chantale L, Madireddi S, Askenasy N and Shirwan H. SA-FasL-engineered allogeneic islets induce robust localized tolerance via apoptosis/phagocytes/CD4+CD25+FoxP3+ T regulatory cell axes. PNAS

2. Madireddi S, Schabowsky RH, Srivastava A, Sharma RK, Yolcu ES and Shirwan H. SA-4-1BBL costimulation inhibits conversion of naïve $\mathrm{CD} 4{ }^{+} \mathrm{T}$ cells into $\mathrm{CD}^{+} \mathrm{CD} 25^{+} \mathrm{FoxP}^{+} \mathrm{T}$ regulatory cells by production of IFN- $\gamma$. Cancer Research

\section{Review Articles:}

1. Schabowsky RH, Madireddi S*, Sharma RK, Yolcu ES and Shirwan H. Targeting CD4+CD25+FoxP3 + regulatory T-cells for the augmentation of cancer immunotherapy. Curr Opin Investig Drugs, 12:1002-8, 2007. [* equal contribution]

2. Schabowsky RH, Sharma RK, Madireddi S, Srivastava A, Yolcu ES and Shirwan H. ProtEx technology for the generation of novel therapeutic cancer vaccines. Exp Mol Pathol. 86:198-207, 2009.

3. Sharma RK, Schabowsky RH, Srivastava A, Yolcu ES, Madireddi S, Shirwan H. Costimulation as a Platform for Development of Safe and Effective Therapeutic Vaccines. Invited Review in Clinical Therapeutics. In preparation.

\section{ABSTRACTS:}

1. Schabowsky RH, Elpek KG, Madireddi S, Sharma RK, Yolcu ES, BanduraMorgan L, Miller R, MacLeod KJ, Mittler RS and Shirwan H. A novel form of 41BBL demonstrates better immunomodulatory activity than an agonistic anti-4-1BB $\mathrm{Ab}$ without $\mathrm{Ab}$ associated severe toxicity. J. Immunol. 182: 41.4. Apr 2009.

2. Sharma R.K, R-H. Schabowsky, A.K. Srivastava, E.S. Yolcu, K.G. Elpek, H. Zhao, Madireddi S, and H. Shirwan. SA-4-1BBL as an immune modulator and vehicle to deliver antigens into dendritic cells for the generation of robust antitumor immune responses. 97th American Association of Immunologists Annual Meeting, May 7-11, Baltimore, MD, 2010. (J. Immunol. May 2010).

\section{POSTER PRESENTATIONS:}

1. Schabowsky R-H., K.G. Elpek, Madireddi S, R.K. Sharma, E.S. Yolcu, L. Bondura-Morgan, R.S. Mittler, and H. Shirwan. A novel form of 4-1BBL 
demonstrates better immunomodulatory activity than an agonistic anti-4-1BB Ab without $\mathrm{Ab}$ associated severe toxicity. American Association of Immunologists (AAI) Annual meeting, Seattle, WA. May, 2009

2. Sharma R.K, R-H. Schabowsky, A.K. Srivastava, E.S. Yolcu, K.G. Elpek, H. Zhao, Madireddi S, and H. Shirwan . SA-4-1BBL costimulatory ligand as an immune modulator and effective vehicle to deliver antigens into dendritic cells for the generation of robust therapeutic antitumor immune responses. 101st American Association for Cancer Research Annual Meeting, Washington, DC. April, 2010.

3. Sharma R.K, R-H. Schabowsky, A.K. Srivastava, E.S. Yolcu, K.G. Elpek, H. Zhao, Madireddi S, and H. Shirwan. SA-4-1BBL as an immune modulator and vehicle to deliver antigens into dendritic cells for the generation of robust antitumor immune responses. American Association of Immunologists (AAI) Annual Meeting, Baltimore, MD. April 2010.

4. Bandura-Morgan, Yolcu ES, Zhao H, Madireddi S, and H Shirwan. A-FasLInduced Localized Allotolerance to Pancreatic Islets Is Mediated by Phagocytes/TGF- $\beta$ Axis. American Association of Immunologists (AAI) Annual meeting, Baltimore, MD. May 2010 